\title{
Signal Protein-Derived Peptides as Functional Probes and Regulators of Intracellular Signaling
}

\author{
Alexander O. Shpakov \\ I.M. Sechenov Institute of Evolutionary Physiology and Biochemistry, Russian Academy of Sciences, Thorez avenue 44, \\ 194223 St. Petersburg, Russia \\ Correspondence should be addressed to Alexander O. Shpakov, alex_shpakov@list.ru
}

Received 31 December 2010; Accepted 1 June 2011

Academic Editor: Andrei Malkov

Copyright ( $) 2011$ Alexander O. Shpakov. This is an open access article distributed under the Creative Commons Attribution License, which permits unrestricted use, distribution, and reproduction in any medium, provided the original work is properly cited.

\begin{abstract}
The functionally important regions of signal proteins participating in their specific interaction and responsible for transduction of hormonal signal into cell are rather short in length, having, as a rule, 8 to 20 amino acid residues. Synthetic peptides corresponding to these regions are able to mimic the activated form of full-size signal protein and to trigger signaling cascades in the absence of hormonal stimulus. They modulate protein-protein interaction and influence the activity of signal proteins followed by changes in their regulatory and catalytic sites. The present review is devoted to the achievements and perspectives of the study of signal protein-derived peptides and to their application as selective and effective regulators of hormonal signaling systems in vitro and in vivo. Attention is focused on the structure, biological activity, and molecular mechanisms of action of peptides, derivatives of the receptors, $\mathrm{G}$ protein $\alpha$ subunits, and the enzymes generating second messengers.
\end{abstract}

\section{Introduction}

The transduction of signals generated by hormones and hormone-like substances of different nature to intracellular effector proteins controlling the fundamental cellular processes requires coordinated activity of many signal proteins, components of a wide spectrum of $G$ protein-coupled and $G$ protein-independent signaling systems, and has several steps in common. The first step is the recognition and specific binding of ligands with extracellular domains of sensors represented by some families of transmembrane proteins, such as the G protein-coupled receptors (GPCRs) seven times penetrating the plasma membrane, the tyrosine kinase receptors having a single transmembrane region (TM) and intracellular domain possessing the intrinsic tyrosine kinase activity, the natriuretic peptide receptors including the membrane-bound guanylyl cyclases, and natriuretic peptide clearance receptor (NPR-C) lacking cyclase activity. The ligand binding is responsible for alteration of conformation of the extracellular regions of receptor and, in the case of GPCRs, for changes of the three-dimensional structure of receptor transmembrane channel (TMC) participating in formation of the ligand-binding site, which starts to transfer the external signal across the plasma membrane and triggers intracellular signaling cascade [1-3]. In the case of $G$ protein-coupled signaling systems the second step of signal transduction is the interaction of intracellular regions of ligand-activated receptor with $\alpha$ subunit and/or $\beta \gamma$ dimer of heterotrimeric G protein in inactive, GDP-bound, state, which induces the GDP/CTP exchange in guanine nucleotide-binding site of $\mathrm{G} \alpha$ subunit and the dissociation of GTP-bound $\mathrm{G} \alpha$ subunit from G $\beta \gamma$ dimer, and the third step is the interaction of GTP-bound G $\alpha$ subunit or free $\mathrm{G} \beta \gamma$ dimeric complex with the enzymes, adenylyl cyclase (AC) and phospholipase C (PLC), generating the second messengers, or with the ionic channels, which significantly amplify the initial signal [4-6]. In the activated state the $\mathrm{G} \alpha$ subunit possesses intrinsic GTPase activity and hydrolyses the bound GTP to GDP, which returns it to the inactive, GDP-bound, state allowing its association with $G \beta \gamma$ dimer to form $\mathrm{G} \alpha \beta \gamma$-heterotrimeric complex [7-10]. In the case of receptors possessing the tyrosine kinase activity the second and the third steps are characterized by the functional interaction between the regulatory and catalytic domains 
located within multifunctional intracellular tail of these sensor proteins, which leads to triggering the cascade of phosphorylation-dephosphorylation of downstream regulatory and effector proteins [11-13]. It should be mentioned that the binding of ligand with the extracellular domain of natriuretic peptide receptor NPR-C leads to interaction between its short cytoplasmic region and $\mathrm{G}$ proteins; the latter, the same as in the case of GPCR, become activated. It seems quite likely that some tyrosine kinase receptors, the epidermal growth factor (EGF) receptor in particular, have a similar mechanism of action [11, 14, 15].

Nowadays it is commonly accepted that the regions of signal proteins participating in their functional interaction and, consequently, responsible for transfer of hormonal signal to cell are rather short and usually contain 8 to 20 amino acid residues [16]. Using different approaches of molecular biology, it is shown that in a majority of cases point mutations in these regions primarily responsible for minimal changes in their conformation drastically influence functional activity of signal proteins and block signal transfer via them. It is not unexpected therefore that the synthetic peptides corresponding to these regions are able to trigger signaling cascades in the absence of hormonal stimulus, modulate protein-protein interaction, and influence the functional activity of signal proteins induced due to changes in their regulatory and catalytic sites. They have been used as important tools in mimicking functional domains of signal proteins, the component of hormonal signaling systems. The present review is devoted to the achievements and perspectives of the study of hormonal signaling systems described in terms of the peptide strategy, a new perspective approach of biochemistry and molecular endocrinology, based on application of synthetic peptides as probes corresponding to functionally important regions of signal proteins, such as receptors of different nature, heterotrimeric $\mathrm{G}$ proteins, and the enzymes generating second messengers and responsible for appropriate response of the cell to external signal.

\section{The Receptors of the Serpentine Type}

As a rule, the serpentine type receptors interact with heterotrimeric $G$ proteins and share a highly conserved transmembrane domain consisting of seven hydrophobic TMs (TM1-TM7) and joined by three extracellular loops, three intracellular loops (ICL1, ICL2, and ICL3), extracellular N-terminal domain, and cytoplasmic C-terminal domain (CTD) [17]. The extracellular loops and $\mathrm{N}$-terminal domain form the external surface of TMC participating in ligandbinding function of the receptor, while the ICLs and CTD interact with a number of signal, regulatory and adaptor proteins, including $\alpha$ and $\beta \gamma$ subunits of G protein, RGSproteins, arrestins, PDZ domain-containing proteins, and G protein-coupled receptor kinases $[18,19]$.

There are numerous data giving evidence that in a majority of GPCRs the membrane-proximal amino- and carboxylterminal regions of ICL3 (N- and C-ICL3), TM3/ICL2 interface containing a highly conserved DRY-motif, and the $\mathrm{N}$ terminal region of CTD (N-CTD) forming in some GPCRs an extra, fourth, loop are involved in the binding and activation of $\mathrm{G}$ proteins and, thus, are responsible for signal transduction via ligand-activated GPCR to intracellular effector proteins $[1,16,20-24]$ (Figure 1). At present the peptides corresponding to these intracellular regions of over 30 GPCRs have been synthesized and their regulatory, and modulatory influence on cellular signaling studied $[16,21$, 25-27]. They are successfully used as functional probes to study GPCR-coupled signaling systems, allowing identification of molecular determinants in intracellular domains of GPCRs responsible for their interaction with $G$ proteins and other signal proteins and elucidation of three-dimensional structure and molecular dynamics of intracellular domains of GPCR in inactive, agonist-free, as well as active, agonistbound, states, revealing the structural-functional organization of oligomeric protein-protein complexes, including receptor molecules, and the role of these complexes in the regulation and control of signal transduction.

One of the first receptors whose structural organization was studied using the peptide strategy is the light-activated sensor protein rhodopsin belonging to the most ancient family of the serpentine type receptors. Proceeding from the data that synthetic peptides corresponding to ICL2, ICL3, and CTD of rhodopsin significantly inhibit interaction between light-activated receptor and $\mathrm{G}_{t}$ protein, transducin, the conclusion was made that the intracellular domains of rhodopsin participate both in binding and in activation of $G_{t}$ protein, which confirms the results of molecular-genetic and crystallographic studies of other authors $[28,29]$. It is shown that effective interaction of peptide with $G_{t}$ protein needs involvement of different regions of these domains since combination of two or three peptides, derivatives of ICL2, ICL3, and CTD, as compared to one, gives a 30-50 fold decrease of $\mathrm{IC}_{50}$ values for inhibitory effects of peptides on GTPase activity of transducin stimulated by light-activated rhodopsin and leads to complete impairment of coupling between the receptor and $G_{t}$ protein.

A majority of biologically active GPCR-peptides correspond to ICL3 and ICL2, which is in good agreement with the important role of these loops in productive interaction of GPCR with G proteins and in hormone-induced signal transfer from the receptor ligand-binding site to the enzymes generating second messengers (Table 1). The peptides, derivatives of ICL3 and ICL2 of $\mathrm{G}_{\mathrm{s}}$-coupled $\beta$-adrenergic receptors (ARs) and $\mathrm{G}_{\mathrm{i} / \mathrm{o}}$-coupled $\alpha_{2}$-AR, selectively bind with $G$ proteins, stimulate their functional activity, trigger signaling cascade in the absence of hormonal stimulus, inhibit the activation of their cognate receptors by selective $\mathrm{AR}$ agonists, as it is shown for peptides derived from the sequence $259-273$ of $\beta_{2}$-AR ICL3 and the sequence 361373 of $\alpha_{2}$-AR ICL3 [30-37]. In the case of the $\mathrm{D}_{1^{-}}$and $\mathrm{D}_{2}$-dopamine receptors (DRs), the 5-hydroxytryptamine receptors (5-HTR) of the type 1 and type 6 as well as the $\mathrm{m}_{2}-$ and $\mathrm{m}_{4}$-muscarinic acetylcholine receptors (MChRs), all of which are coupled with $\mathrm{G}_{\mathrm{s}}\left(\mathrm{D}_{1}-\mathrm{DR}, 5-\mathrm{HT}_{6} \mathrm{R}\right)$ or $\mathrm{G}_{\mathrm{i} / \mathrm{o}}$ proteins $\left(\mathrm{D}_{2}-\mathrm{DR}, 5-\mathrm{HT}_{1 \mathrm{~A}, 1 \mathrm{~B}, 1 \mathrm{D}} \mathrm{R}, \mathrm{m}_{2 / 4}-\mathrm{MChR}\right)$, and also $\mathrm{m}_{3}-\mathrm{MChR}$ coupled with $\mathrm{G}_{\mathrm{q}}$ protein it is shown that the peptides, derivatives of the membrane-proximal regions of ICL3, especially C-ICL3, selectively bind and activate G 


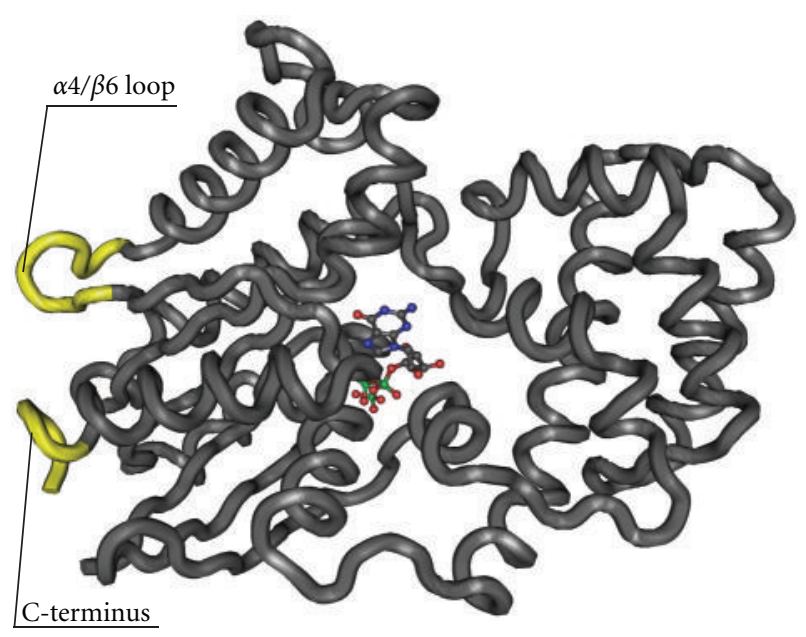

FIGURE 1: The regions of GTP-bound $\mathrm{G} \alpha_{\mathrm{il}}$ subunit (yellow) responsible for its specific interaction with ligand-activated receptor.

proteins and inhibit their functional interaction with their cognate receptor upon agonist activation [30, 32, 38-44] (Table 1).

There are many works demonstrating that the peptides corresponding to ICL3 of GPCRs that are activated by the peptide and protein hormones influence GPCR-signaling with high efficiency and selectivity. The ICL3-peptide 237261 of the $\delta$-opioid receptor blocks high-affinity binding of $\delta$-agonists, significantly decreases $\mathrm{G}_{\mathrm{i} / \mathrm{o}}$-mediated AC inhibition and PLC activation following the stimulation of the $\delta$ opioid receptor, but has no influence on $\mathrm{G}_{\mathrm{s}}$ - and $\mathrm{G}_{\mathrm{q}}$-coupled signaling cascades regulated via the same receptor [45]. The peptides corresponding to ICL3 of the luteinizing hormone receptor, the follicle-stimulating hormone (FSH) receptor, the relaxin receptor of the type 1 (RXFP1), the glucagon-like peptide-1 receptor (GLP1Rs) and the parathyroid hormone receptor selectively activate distinct types of $\mathrm{G}$ proteins and influence signal transduction via their cognate receptors [4653] (Table 1).

The cyclic and dimeric forms of GPCR-peptides, as a rule, possess higher activity compared with linear peptides as their three-dimensional structure is more similar to that of the corresponding loop in intact receptor. Among the peptides, derivatives of $\alpha_{2}$-AR ICL3, the most potent activator of $\mathrm{G}_{\mathrm{i} / \mathrm{o}}$ proteins is dimeric constrain formed by cross-linked peptides, derivatives of $\mathrm{N}$ - and C-ICL3 [31, 54]. A cyclic peptide 225-273 mimicking the full-length ICL-3 of $\mathrm{G}_{\mathrm{s}}$-coupled $\mathrm{V}_{2}$-vasopressin receptor activates $\mathrm{G}_{\mathrm{s}}$ proteins and significantly inhibits the AC activity stimulated both by vasopressin and by guanine nucleotides, its action on vasopressin-regulated AC system being more potent compared with linear analogs [55].

The membrane-proximal N-CTD in some GPCRs forms additional, fourth, intracellular loop and participates in the interaction with GPCR-coupled downstream signal proteins, $\mathrm{G}$ proteins in particular. The same refers to peptide 401-417 corresponding to $\mathrm{N}-\mathrm{CTD}$ of the $\mathrm{CB}_{1}$-cannabinoid receptor, which, like ICL3-peptides 301-317 and 329-344, stimulates
GTP $\gamma \mathrm{S}$ binding of $\mathrm{G}_{\mathrm{i}}$ proteins and inhibits forskolinstimulated AC activity [56-58] (Table 1). As for N-CTDpeptide 645-653 of FSH receptor and its short analog, they significantly reduce FSH-stimulated estradiol synthesis in cultured Sertoli cells and increase the GDP/GTP exchange of $G$ proteins in the rat testis membranes [46, 47]. The fact that the peptides corresponding to the membraneproximal regions of ICL2, ICL3, and CTD of the type 1 angiotensin II receptor activate $G$ proteins and inhibit angiotensin II-induced stimulation of their GTPase activity suggests these regions, the same as rhodopsin, to be involved in the interaction with $\mathrm{G}$ proteins [59-62]. Concerning Nformyl peptide receptor (FPR1), peptides 119-133, 122-144, 126-137, and 134-150 corresponding to ICL2, TM3/ICL2, and ICL2/TM4 interfaces as well as CTD-peptides 308322, 319-340, and 322-336 directly interact with the Cterminal region of $\mathrm{G} \alpha_{\mathrm{i} / \mathrm{o}}$, inhibit interaction of $\mathrm{G}_{\mathrm{i} / \mathrm{o}}$ proteins with hormone-activated receptor, and decrease high affinity ligand binding to the receptor, while peptides 210-224, 227239, and 230-245 corresponding to ICL3, TM5/ICL3, and ICL3/TM6 interfaces have little or no influence on $\mathrm{G}$ protein and receptor activities and so do not interfere with their coupling $[63,64]$. It is not typical of $G$ protein-binding and -activating surfaces of the receptor to be formed by ICL2 and CTD, so much so as ICL3 is not involved in interaction with G proteins.

Despite the fact that ICL1 in a majority of GPCRs does not participate in interaction with G proteins, peptide 39-51 corresponding to ICL1 of prostacyclin receptor specifically interacts with the C-terminal region of $\mathrm{G} \alpha$ s and, thus, activates $G_{s}$ protein and stimulates $A C$ activity. All this indicates an important role of ICL1 of this receptor in $\mathrm{G}_{\mathrm{s}}$ protein coupling $[65,66]$ (Table 1). Another example is ICL1 of GLP1R participating, like ICL3, in the interaction with $G$ proteins. The evidence for this stems from the fact that peptide 169-176 corresponding to ICL1 of GLP1R significantly activates $G_{s}$ and $G_{i}$ proteins and influences hormone-stimulated AC activity [53].

The action of many GPCR-peptides on G proteins is very selective (Table 1 ). N-CTD-peptide $401-417$ of $\mathrm{CB}_{1}$ cannabinoid receptor decreases significantly the interaction of its cognate receptor with $\mathrm{G} \alpha_{\mathrm{i} 3}$ subunit, but not with $\mathrm{G} \alpha_{\mathrm{i} 1}$ and $\mathrm{G} \alpha_{\mathrm{i} 2}$, whereas peptides 301-317 and 329-344 disturb receptor-mediated activation of $\mathrm{G} \alpha \alpha_{\mathrm{i} 1}$ and $\mathrm{G} \alpha \alpha_{\mathrm{i} 2}$ subunits, but not $\mathrm{G} \alpha_{\mathrm{i} 3}[56,57]$. Peptide 483-497 corresponding to C-ICL3 of $\mathrm{G}_{\mathrm{q}}$-coupled $\mathrm{m}_{3}-\mathrm{MChR}$ at micromolar concentrations selectively activates $G_{q}$ but not $G_{i 2}$ proteins [43], while peptide 260-267 corresponding to C-ICL3 of $\mathrm{G}_{\mathrm{s}}$-coupled $\mathrm{D}_{1}$-DR selectively activates $\mathrm{G}_{\mathrm{s}}$ proteins [38]. Peptides 206224, 214-231, and 213-225 derived from N-ICL3 of $\mathrm{D}_{2-}$ $\mathrm{DR}, 5-\mathrm{HT}_{1 \mathrm{~A}} \mathrm{R}$, and $5-\mathrm{HT}_{1 \mathrm{D}} \mathrm{R}$ and peptides $382-400$ and 285-298 derived from C-ICL3 of $\mathrm{m}_{4}-\mathrm{MChR}$ and $5-\mathrm{HT}_{1 \mathrm{D}} \mathrm{R}$ stimulate preferably $\mathrm{G}_{\mathrm{i} / \mathrm{o}}$ proteins and have little or no effect on the other $G$ protein types $[30,32,40-42]$. The $\mathrm{N}$ ICL3-peptide 216-231 of the type 1 angiotensin II receptor coupled with the $G_{i / o}$ and with the $G_{q / 11}$ proteins selectively activates purified $\mathrm{G}_{\mathrm{i} / \mathrm{o}}$ proteins, while C-ICL3-peptide 230241 activates purified $\mathrm{G}_{\mathrm{q} / 11}$ proteins $[59,61]$. We have shown that peptides 615-629 and 258-268 corresponding 
TABLE 1: The peptides, derivatives of signal proteins, and their biological activity.

\begin{tabular}{|c|c|c|c|}
\hline Signal protein & Sequence & Activity & References \\
\hline$\alpha_{2}-\mathrm{AR}(\mathrm{C}-\mathrm{ICL} 3)$ & $\begin{array}{l}\text { RWRGRQNREKRFTC }{ }^{361-373} \text { and its dimeric } \\
\text { constrain with N-ICL3-peptide } \\
\text { RIYQIAKRRTR }^{233-243}\end{array}$ & $\begin{array}{l}\text { Both selectively stimulate } \mathrm{G}_{\mathrm{i} / \mathrm{o}} \\
\text { proteins and inhibit } \alpha_{2} \text {-AR } \\
\text { agonist-stimulated GTPase activity }\end{array}$ & {$[30-32]$} \\
\hline$\beta_{2}-\mathrm{AR}(\mathrm{C}-\mathrm{ICL} 3)$ & RRSSKFCLKEKKALK ${ }^{259-273}$ & $\begin{array}{l}\text { Selectively stimulates } G_{s} \text { proteins } \\
\text { and decreases regulatory effects of } \\
\beta_{2} \text {-AR agonists }\end{array}$ & {$[33-35]$} \\
\hline $\begin{array}{l}\mathrm{D}_{1}-\mathrm{DR}(\mathrm{C}-\mathrm{ICL} 3, \mathrm{I}) \\
5-\mathrm{HT}_{6} \mathrm{R}(\mathrm{C}-\mathrm{ICL} 3, \mathrm{II})\end{array}$ & $\begin{array}{l}\text { FKMSFKRETKVLKTLSV }{ }^{260-276} \text { (I); } \\
\text { KHSRKALKASL }^{258-268} \mathrm{~K}(\mathrm{II})\end{array}$ & $\begin{array}{l}\text { Stimulate } \mathrm{G}_{\mathrm{s}} \text { proteins and } \mathrm{AC} \\
\text { activity, decrease the stimulating } \\
\text { effects of } \mathrm{D}_{1}-\mathrm{DR} \text { (peptide I) and } \\
5-\mathrm{HT}_{6} \mathrm{R}(\mathrm{II}) \text { on } \mathrm{AC} \text { system }\end{array}$ & {$[38,39]$} \\
\hline $\begin{array}{l}\mathrm{D}_{2}-\mathrm{DR}(\mathrm{N}-\mathrm{ICL} 3, \mathrm{I}) \\
5-\mathrm{HT}_{1 \mathrm{~A}} \mathrm{R}(\mathrm{N}-\mathrm{ICL} 3 \\
\mathrm{II}) ; 5-\mathrm{HT}_{1 \mathrm{~B}} \mathrm{R} \\
\text { (C-ICL3, III); } \\
5-\mathrm{HT}_{1 \mathrm{D}} \mathrm{R}(\mathrm{N}-\mathrm{ICL} 3 \\
\mathrm{IV} ; \mathrm{C}-\mathrm{ICL} 3, \mathrm{~V}) ; \\
\mathrm{m}_{4}-\mathrm{MChR}(\mathrm{C}-\mathrm{ICL} 3 \\
\mathrm{VI})\end{array}$ & $\begin{array}{l}\text { VYIKIYIVLRRRRKRVNTK }{ }^{206-224}(\mathrm{I}) ; \\
\text { LYGRIFRAARFRIRKTVK }^{214-231}(\mathrm{II}) ; \\
\text { ARERKATKTL }^{307-316}(\mathrm{III}) ; \\
\text { LYGRIYVAARSRI }^{213-225}(\mathrm{IV}) ; \\
\text { RKRISAARERKATK }^{285-298}(\mathrm{~V}) ; \\
\text { RNQVRKKRQMAARERKVTR }^{382-400}(\mathrm{VI})\end{array}$ & $\begin{array}{l}\text { Selectively activate } \mathrm{G}_{\mathrm{i} / \mathrm{o}} \text { proteins and } \\
\text { inhibit forskolin-stimulated } \mathrm{AC} \\
\text { activity in the absence of hormone; } \\
\text { inhibit signaling via their cognate } \\
\mathrm{G}_{\mathrm{i} / \mathrm{o}} \text {-coupled receptors }\end{array}$ & $\begin{array}{l}{[30,32} \\
39-42]\end{array}$ \\
\hline $\mathrm{m}_{3}-\mathrm{MChR}(\mathrm{C}-\mathrm{ICL} 3)$ & LVKEKKAAQTLSAILL $^{483-497}$ & $\begin{array}{l}\text { Selectively activates } \mathrm{G}_{\mathrm{q}} \text { and } \\
\text { influences } \mathrm{m}_{3}-\mathrm{MChR} \text {-mediated } \\
\text { signaling }\end{array}$ & {$[43]$} \\
\hline $\begin{array}{l}\delta \text {-opioid receptor } \\
(\mathrm{ICL} 3)\end{array}$ & MGRLRSVRLLSGSKEKDRSLRRITR ${ }^{237-261}$ & $\begin{array}{l}\text { Blocks } \delta \text {-agonist-induced PLC } \\
\text { activation, } \mathrm{Ca}^{2+} \text { release and cAMP } \\
\text { signaling }\end{array}$ & {$[45]$} \\
\hline $\begin{array}{l}\text { Luteinizing hormone } \\
\text { receptor; FSH } \\
\text { receptor }(\mathrm{C}-\mathrm{ICL} 3, \mathrm{II}) \text {; } \\
\text { relaxin receptor } \\
\text { RXFP1 (C-ICL3, III); } \\
\text { parathyroid hormone } \\
\text { receptor }(\mathrm{C}-\mathrm{ICL} 3, \mathrm{IV})\end{array}$ & $\begin{array}{l}\text { FAVQNPELMATNKDTKIAKK }{ }^{551-570} \text { (I), } \\
\text { HIYLTVRNPNIVSSSSDTRIAKR } \\
\text { and EIRNQ-555 (II), } \\
\text { and their short analogs; } \\
\text { EYRKLLK }^{402-408} \text { (IV) }\end{array}$ & $\begin{array}{l}\text { Activate preferably } \mathrm{G}_{\mathrm{s}} \text { proteins and } \\
\text { stimulate the basal AC activity, } \\
\text { inhibit agonist-induced signaling } \\
\text { via their cognate receptors }\end{array}$ & {$[46-52]$} \\
\hline $\begin{array}{l}\text { GLP1R (ICL1 and } \\
\text { ICL3) }\end{array}$ & $\begin{array}{l}\text { FRHLHCTR }{ }^{169-176} \text {; } \\
\text { IVIAKLKANLMCKTDIKCRLAK } \\
330-351\end{array}$ & $\begin{array}{l}\text { Activate preferably } \mathrm{G}_{\mathrm{s}} \text { and } \mathrm{G}_{\mathrm{i}} \\
\text { proteins, inhibit hormone- } \\
\text { stimulated AC activity }\end{array}$ & {$[53]$} \\
\hline $\begin{array}{l}\mathrm{V}_{2} \text {-vasopressin } \\
\text { receptor (ICL3) }\end{array}$ & $\begin{array}{l}\text { Cyclo-QVLIFREIHASLVPGPSERAG- } \\
\text { RRRRGRRTGSPSEGAHVSAAMAKT- } \\
\text { VRMT }^{225-273}\end{array}$ & $\begin{array}{l}\text { Decreases the affinity of agonist for } \\
\text { the receptor and inhibits } \\
\text { vasopressin-stimulated AC activity }\end{array}$ & {$[55]$} \\
\hline $\begin{array}{l}\mathrm{CB}_{1} \text {-cannabinoid } \\
\text { receptor (N-ICL3, I; } \\
\text { C-ICL3, II, and } \\
\text { N-CTD, III) }\end{array}$ & $\begin{array}{l}\text { KAHSHAVRMIQRGTQKS } \\
\text { QVTR-317 (I); } \\
\text { RSKDLRQAARMDIRLAK }^{329-344} \text { (II); }\end{array}$ & $\begin{array}{l}\text { Selectively stimulate different } \\
\text { isoforms of the } \alpha \text {-subunits of } \mathrm{G}_{\mathrm{i}} \\
\text { proteins and significantly inhibit } \\
\text { AC activity }\end{array}$ & {$[56-58]$} \\
\hline $\begin{array}{l}\text { Angiotensin II } \\
\text { receptor of the type } 1 \\
\text { (ICL2, I; N-ICL3, II; } \\
\text { C-ICL3, III, N-CTD, } \\
\text { IV) }\end{array}$ & $\begin{array}{l}\text { DRYLAIVHPMKSR } \\
\text { TLIWK-137 (I); } \\
\text { KNKPRNLKKAYEIQKN }^{216-231} \text { (II); } \\
\text { FLGKKFKKYFLLQ }^{230-241}(\mathrm{III}) ; \\
\end{array}$ & $\begin{array}{l}\text { Inhibit angiotensin-induced } \\
\text { activation of } G \text { proteins and the } \\
\text { effector enzymes; peptide II } \\
\text { selectively activates } \mathrm{G}_{\mathrm{i} / \mathrm{o}} \text { proteins, } \\
\text { peptide III } \mathrm{G}_{\mathrm{q} / 11} \text { proteins }\end{array}$ & {$[59-62]$} \\
\hline $\begin{array}{l}\text { FPR1 (ICL2, I; } \\
\text { N-CTD, II) }\end{array}$ & $\begin{array}{l}\text { CVLHPVWTQNHR }^{126-137}(\mathrm{I}) ; \\
\text { FRERLIHALPASLER }^{308-322} \text { (II) }\end{array}$ & $\begin{array}{l}\text { Activate in a PTX-dependent } \\
\text { manner } G_{i} \text { proteins; peptide II } \\
\text { inhibits high affinity agonist } \\
\text { binding to the receptor and its } \\
\text { coupling to } G_{i} \text { protein }\end{array}$ & {$[63,64]$} \\
\hline $\begin{array}{l}\text { Prostacyclin receptor } \\
\text { (ICL1) }\end{array}$ & SARRPARPSAFAV ${ }^{39-51}$ & $\begin{array}{l}\text { Selectively stimulates } \mathrm{G}_{\mathrm{s}} \text { proteins } \\
\text { and the basal activity of AC }\end{array}$ & {$[65,66]$} \\
\hline $\begin{array}{l}\text { Insulin receptor } \\
\text { (tyrosine kinase } \\
\text { region) }\end{array}$ & N-stearyl-TRDIYETDYYRK ${ }^{1142-1153}$ & $\begin{array}{l}\text { Increases insulin- and } \\
\text { vanadate-stimulated } \\
\text { phosphorylation of IR; significantly } \\
\text { enhances insulin-induced } \\
\text { stimulation of PI3K and MAPK } \\
\text { activities }\end{array}$ & {$[67]$} \\
\hline
\end{tabular}


Table 1: Continued.

\begin{tabular}{lll}
\hline Signal protein & Sequence & Activity \\
\hline $\begin{array}{l}\text { Insulin receptor } \\
\text { (C-terminal region) }\end{array}$ & N-stearyl-SSHCQREEAGGRDGG & Enhances insulin-stimulated \\
& & $\begin{array}{l}\text { autophosphorylation; increases } \\
\text { insulin-stimulated PI3K and MAPK } \\
\text { activities }\end{array}$ \\
\hline EGF receptor & & [68]
\end{tabular}

(N-terminal region of

the juxtamembrane

RRREIVRKRTLRR ${ }^{646-658}$

Activates $G_{s}$ proteins, influences

activity of $G_{i}$ proteins

[69]

domain)

$\begin{array}{ll}\text { NPR-C (cytoplasmic } & \text { KKYRITIERRNH }^{461-472} ; \\ \text { domain) } & \text { RRNHQEESNIGK }{ }^{469-480} ; \\ & \text { RRNHQEESNIGKHRELR } \\ & \text { HRELREDSIRSH } \\ & \text { H81-492 } \text { and their analogs }\end{array}$

NPR-C (extreme

$\mathrm{C}$-terminal region of

the cytoplasmic

domain)

\begin{tabular}{ll}
$\mathrm{G} \alpha_{\mathrm{t}}$ & IKENLKDCGLF $^{340-350}$ \\
\hline $\mathrm{G} \alpha_{\mathrm{s}}$ & $\begin{array}{l}\text { RVFNDARDIIQRMHLRQYELL } \\
\text { its short analogs }\end{array}$ \\
\hline
\end{tabular}

G $\alpha_{\mathrm{s}}$ (Switch I and II regions, resp.)

$\mathrm{G} \alpha_{\mathrm{s}}(\alpha 3-\beta 5$ region $)$

EALNLFKSIWNNRWL-RTIS $268-286$

IKPAKRMKFKTVCYLLVQLMHCRKMF-

$\mathrm{AC1}\left(\mathrm{C}_{1 \mathrm{~b}}\right.$ subdomain $)$

$\mathrm{KA}^{495-522}$

$\left(\mathrm{pAC} 28, \mathrm{C}_{1 \mathrm{~b}}\right)$

$\begin{array}{ll}\text { AC1 }\left(\mathrm{C}_{2 \mathrm{a}} \text { subdomain }\right) & \begin{array}{l}\text { TEEVHRLLRRGS-YRFVCRGKV } \\ \left(\mathrm{pVLG}, \mathrm{C}_{2 \mathrm{a}}\right)\end{array}\end{array}$

YTESDVNKEGLECLRLLNEIIADFD-

$\operatorname{DLL}^{899-926}(\alpha 2, \mathrm{I})$;

SKPKFSGVEKIKTIGSTYMAAT ${ }^{927-948}$

$\mathrm{AC} 2\left(\mathrm{C}_{2}\right.$ domain $)$

$(\beta 2-\beta 3, \mathrm{II})$;

DAINKHSFNDFKLRVGINHGPVIA-

GVIGAQK $^{984-1015}$

$(\alpha 3-\beta 4$, III $)$

AAENHCLRIKILGDCYYC ${ }^{427-444}$

$(\alpha 2-\beta 2-\beta 3, \mathrm{I})$;

AC6 ( $\mathrm{C}_{1}$ domain $)$
IHSGRVHCGVLGLRKWQFDVWSN-

$\mathrm{DV}^{487-511}$

$(\beta 4-\beta 5-\alpha 4, \mathrm{II})$
Inhibit the basal, forskolin- and

hormone-stimulated AC activity;

selectively increase GTP binding

activity of $\mathrm{G}_{\mathrm{i} 1}$ and $\mathrm{G}_{\mathrm{i} 2}$ proteins;

stimulate PLC $\beta 3$ activity; inhibit

[70-72]

hormone-stimulated DNA synthesis

in vascular smooth muscle cells;

induce smooth muscle contraction

Inhibits ANP(4-23)-induced $\mathrm{G}_{\mathrm{i}}$

protein activation and cellular

responses acting as a competitive

inhibitor of ANP(4-23)-mediated

[71]

signaling

Stabilizes the active state of opsin

and meta-II-rhodopsin and

meta-Ib-rhodopsin;

Inhibit transduction of hormonal

signal via $\mathrm{G}_{\mathrm{s}}$-coupled receptors

Increase the basal and

forskolin-stimulated AC2 and AC6

activities; inhibit $\mathrm{G} \alpha_{\mathrm{s}}$-stimulated

activity of both AC isoforms;

behave as partial agonist

Inhibits the basal and

forskolin-stimulated activities of

AC2 and AC6; significantly

decreases the $\mathrm{G} \alpha_{\mathrm{s}}$-stimulated

enzyme activity

Binds CaM with high affinity in a

$\mathrm{Ca}^{2+}$-independent manner; inhibits

CaM-stimulated AC activity with

$[79,80]$

$\mathrm{IC}_{50}$ equal to $500 \mathrm{nM}$

Binds CaM with low affinity in a

$\mathrm{Ca}^{2+}$-dependent manner; inhibits

CaM-stimulated AC activity with

$[80]$

$\mathrm{IC}_{50}$ is $10 \mu \mathrm{M}$

All peptides inhibit $\alpha_{\mathrm{s}}$ - and

forskolin-stimulated activities of

AC2 and AC6; peptides I and III

inhibit the basal AC activity;

$[81]$

peptide I decreases

$\mathrm{Mn}^{2+}$-stimulated activity

Both peptides inhibit $\alpha_{\mathrm{s}}$ - and

forskolin-stimulated AC activities;

peptide II inhibits the basal activity

$[81]$

of both AC2 and AC6 
TABle 1: Continued.

\begin{tabular}{|c|c|c|c|}
\hline Signal protein & Sequence & Activity & References \\
\hline $\operatorname{PLC} \beta 1 b$ & $\begin{array}{l}\text { N-Myristoyl-TPPNPQALKW }{ }^{1164-1173} \text { (I); } \\
\text { GEGSSSVLSESCHEDPSVPPNFTPP- } \\
\text { NPQALKW }^{1142-1173} \text { (II) }\end{array}$ & $\begin{array}{l}\text { Both peptides dissociate the enzyme } \\
\text { from membrane and inhibit PLC } \\
\text { stimulation by hormones; peptide } \\
\text { II prevents cardiomyocytes } \\
\text { hypertrophy }\end{array}$ & {$[82,83]$} \\
\hline $\operatorname{PLC} \beta 3$ & QEENTQL $^{1161-1167}$ & $\begin{array}{l}\text { Significantly inhibits intracellular } \\
\text { calcium response to selective } \\
\text { agonists of mGluR }\end{array}$ & {$[84]$} \\
\hline $\operatorname{PLC} \gamma$ & $\begin{array}{l}\text { GLYRKAMRLRYPV } \\
\text { N-myristoylated analogs }\end{array}$ & $\begin{array}{l}\text { Specifically inhibit PLC activity and } \\
\text { PLC-dependent cellular processes }\end{array}$ & {$[85]$} \\
\hline PLC $\delta 1$ (IQ-peptide) & VRSQVQHKPKEDKLKLVPELS ${ }^{473-493}$ & $\begin{array}{l}\text { Inhibits PLC activity; binds CaM in } \\
\mathrm{Ca}^{2+} \text {-independent manner }\end{array}$ & {$[86]$} \\
\hline $\operatorname{PLC} \delta 1$ & $\begin{array}{l}\text { N-Myristoyl- } \\
\text { TIPWNSLKQGYRHVHLL } \\
\end{array}$ & Inhibits $\mathrm{FSH}$-induced $\mathrm{Ca}^{2+}$ influx & {$[87]$} \\
\hline $\begin{array}{l}\text { Regulatory } \\
\text { p85-subunit of PI3K } \\
\text { (C-terminal region of } \\
\text { N-terminal SH2 } \\
\text { domain) }\end{array}$ & WNVGSSNRNKAENLLRGKR ${ }^{11-29}$ & $\begin{array}{l}\text { Exhibits binding specificity and } \\
\text { affinity for PI } 3,4,5-\mathrm{P}_{3} \text { and inhibits } \\
\text { PI 3,4,5-P }- \text {-binding to the p } 85 \\
\text { subunit }\end{array}$ & {$[88]$} \\
\hline $\begin{array}{l}\mathrm{PKC} \zeta \\
\text { (pseudosubstrate } \\
\text { region) }\end{array}$ & N-Myristoyl-SIYRRGARRWRKL ${ }^{114-126}$ & $\begin{array}{l}\text { Inhibits PKC } \zeta \text { activity; stimulates } \\
\text { Akt, ERK1/2, p38 MAPK and eNOS } \\
\text { activity }\end{array}$ & {$[89]$} \\
\hline $\begin{array}{l}\mathrm{PKC} \eta \\
\text { (pseudosubstrate } \\
\text { region) }\end{array}$ & $\begin{array}{l}\text { N-Myristoyl- } \\
\text { RKRQRAMRRRVHQING }\end{array}$ & $\begin{array}{l}\text { Inhibits } \mathrm{PKC} \eta \text { activity; stimulates } \\
\text { eNOS phosphorylation }\end{array}$ & {$[89]$} \\
\hline
\end{tabular}

to $\mathrm{C}-\mathrm{ICL} 3$ of the relaxin receptor $\mathrm{RXFP1}$ and $5-\mathrm{HT}_{6} \mathrm{R}$ at micromolar concentrations stimulate $\mathrm{AC}$ activity and increase the basal level of GTP binding of $\mathrm{G}_{\mathrm{s}}$ proteins but do not affect the other types of $G$ proteins, in particular the $\mathrm{G}_{\mathrm{i}}$ proteins associated with AC in the inhibitory manner [39]. The treatment of membrane fraction with pertussis toxin (PT) inactivating $\mathrm{G}_{\mathrm{i}}$ proteins does not influence the effects of peptides 615-629 and 258-268, whereas the treatment with cholera toxin impairing the function of $G_{s}$ proteins blocks these effects. In the presence of peptide derived from C-terminal segment of the $\mathrm{G} \alpha_{\mathrm{s}}$ subunit the effects of both peptides are significantly decreased. This is due to competition between the full-size $\mathrm{G} \alpha_{\mathrm{s}}$ and C-terminal $\mathrm{G} \alpha_{\mathrm{s}}$ peptide for binding with GPCR-peptide, and is the evidence of participation of $\mathrm{G}_{\mathrm{s}}$ protein in the mechanism of action of GPCR-peptide. Besides, the peptide corresponding to $\mathrm{G} \alpha \mathrm{i}$ terminal segment does not affect the activity of peptides 615629 and 258-268, derivatives of $\mathrm{G}_{\mathrm{s}}$-coupled receptors. The C-ICL3-derived peptide 300-316 of $\mathrm{G}_{\mathrm{i}}$-coupled $5-\mathrm{HT}_{1 \mathrm{~B}} \mathrm{R}$ increases GTP binding activity of $\mathrm{G}_{\mathrm{i}}$ protein but does not affect the other $G$ proteins. This effect is blocked by PT treatment and reduced in the presence of C-terminal $\mathrm{G} \alpha_{\mathrm{i}^{-}}$ peptide [39].

The $\mathrm{G}$ protein-interacting regions of GPCRs are usually positively charged and contain BBXXB, BBXB, and the related motifs, where $B$ is a basic amino acid residue (Arg or Lys) and $X$ is another residue [30, 90, 91], specifically interact with the negatively charged C-terminal region of $\mathrm{G} \alpha$ subunits that is of prime importance for recognition and effective interaction of different types of $G$ proteins with ligand-activated GPCR [42, 92-94]. In addition to the extreme C-terminus of $\mathrm{G} \alpha$, the $\alpha 4$ helix and the $\alpha 4 / \beta 6$ loop rich in negatively charged amino acid residues also participate in a receptor- $G$ protein coupling [32]. As a result, the presence of BBXXB and the related motifs in GPCRpeptides, derivatives of receptor intracellular domains, is a very important structural feature required for their effective and selective interaction with $\mathrm{G}$ proteins. The substitution of the positively charged $\mathrm{Lys}^{221}$ and $\mathrm{Arg}^{222}$ in C-terminal segment of N-ICL3-peptide $208-226$ of $\mathrm{G}_{\mathrm{i} / \mathrm{o}}$-coupled $\mathrm{D}_{2}$-DR by alanine residues leads to a 3 -fold reduction in its affinity for $\mathrm{G} \alpha_{\mathrm{i} / \mathrm{o}}$ [42]. Consistent with that, mutant $\mathrm{D}_{2}-\mathrm{DR}$ with the substitution of segment RRRR ${ }^{217-220}$ in N-ICL3 by AAAA is not capable of effective interaction with $\mathrm{G}_{\mathrm{i} / \mathrm{o}}$ proteins and is insensitive to agonist activation. These findings support the view that charge-charge complementation has a very important role in receptor-G $\alpha$ coupling $[95,96]$.

The peptide strategy makes it possible to produce analogs of GPCR-peptides with a higher biological activity and to deliver them to the intracellular effector proteins of the target cells, which is very important for their application as a new generation of highly effective and selective GPCRbased drugs. The most perspective way to achieve this goal is modification of GPCR-peptides using either hydrophobic radicals, for example, $\mathrm{C}_{12}-\mathrm{C}_{18}$ acyl or steroid group, or hydrophobic TM fragment; they mimic the receptor TM, maintain the peptide conformation close to that in native receptor, and, finally, allow the transfer of peptide across the 
plasma membrane. Such cell-penetrating lipidated peptides are designated as pepducins. The latter corresponding to ICLs of the protease-activated receptors (PAR1, PAR2, PAR4), the chemokine receptors (CXCR1, CXCR2, CXCR4, CCR5), the sphingosine-1-phosphate (S1P) receptor, the relaxin receptor RXFP1, $\alpha_{1 \mathrm{~B}}-\mathrm{AR}, 5-\mathrm{HT}_{1 \mathrm{~B}} \mathrm{R}$, and $5-\mathrm{HT}_{6} \mathrm{R}$ function as intracellular agonists or antagonists of their cognate receptors and their action is realized at the stage of specific interaction between the receptor and $G$ protein on the intracellular plasma membrane surface $[39,49,50$, 97102]. Pepducins can be used to control platelet-dependent hemostasis and thrombosis, tumor growth, invasion, angiogenesis, as well as to prevent some inflammatory diseases $[26,27,100,103-109]$.

With respect to the specificity and efficiency of action on their cognate receptors, pepducins significantly surpass unmodified analogs, which makes them very perspective selective regulators of hormonal signaling systems [39, 50, 98-100, 105, 110, 111]. Peptide Pal-RCLSSSAVANRS ${ }^{295-306}$ (P1pal-12) corresponding to N-ICL3 of $\mathrm{G}_{\mathrm{q} / 11^{-}}$and $\mathrm{G}_{\mathrm{i}^{-}}$ coupled PAR1 functions as a selective PAR1 antagonist and inhibits the increase in inositol triphosphate production and concentration of intracellular $\mathrm{Ca}^{2+}$ induced by agonistactivated receptor, significantly decreases platelet aggregation in response to PAR1 agonist SFLLRN and the vasorelaxation caused by other PAR1 agonist TFLLR-amide in the rat aorta, but does not affect the vasorelaxation caused by PAR2 agonist SLIGRL-amide, neither does it inhibit PAR4dependent platelet aggregation $[98,112]$. This peptide has no effect on the aggregation in response to agonists of the thromboxane, ADP, collagen, and GPIb/IX/V receptors the same as the lack of effect on the response to interleukin8 , stromal-derived factor $1 \alpha, \mathrm{S} 1 \mathrm{P}$, monocyte chemotactic protein-1, RANTES (Regulated on Activation Normal T cell ExpreSsed) in endothelial cells, or the migration of recombinantly transfected HEK293 cells to ligands of PAR2, PAR4, CXCR1, CXCR2, CCR5, or S1P receptors [98, 105]. Peptide Pal-RCLSSSAVANRSKKSRALF ${ }^{295-313}$ (P1pal-19), a derivative of PAR1 ICL3, possesses the activity of PAR1 agonist and, like selective PAR1 agonists TFLLR and SFLLRN, stimulates the $G_{q}$ and $G_{i / o}$ proteins and PLC $\beta$ activities, produces endothelial NO-dependent relaxation in the rat aorta, and promotes prostaglandin $\mathrm{E}_{2}$ release in the human lung epithelial cells and the rat gastric mucosal epithelial cells $[97,98,112]$. The action of P1pal-19 is very specific to PAR1 and its influence is drastically reduced or completely blocked in cultured cells and the tissues where its cognate receptor is absent or mutant form of PAR1 is expressed.

The ICL3-peptide Pal-SGRRYGHALR ${ }^{274-283}$ (P4pal-10) of PAR4 functions as an antagonist of its cognate receptor and a partial antagonist of PAR1. It completely inhibits PLC $\beta$ stimulation and $\mathrm{Ca}^{2+}$ response induced by PAR4 agonist AYPGKF-amide and decreases the analogous effects of PAR1 agonist SFLLRN-amide by 36\%. P4pal-10 completely blocks platelet aggregation induced by PAR4 agonist and partially inhibits PAR1 agonist-induced aggregation, whereas it has no effect on the aggregation of platelets induced by a series of agonists of the GPCRs which do not belong to the PAR family, neither on the migration of human neutrophils to interferon- $\gamma$-inducible protein-10, stromal-derived factor $1 \alpha$, and S1P but completely blocks migration to thrombin activating both PAR1 and PAR4 [98, 111]. ICL1-peptide PalATGAPRLPST ${ }^{103-112}$ (P4pal-i1) of PAR4 is more selective compared with peptide P4pal-10. It completely blocks the chemotactic response realized via PAR4 and prevents platelet aggregation triggered by PAR4 agonist AYPGKF-amide but does not inhibit the chemotactic response of PAR1 and does not affect platelet aggregation induced by PAR1 agonist SFLLRN-amide $[106,113]$. When P4pal-i1 is combined with thrombin inhibitor bivalirudin, inhibition of human platelet aggregation and suppression of arterial thrombosis in guinea pigs increases to a much higher degree than with bivalirudin alone [106]. The data concerning thrombolytic action of peptides P4pal-10 and P4pal-i1 and ICL-peptides of other PARs show that on their basis it is possible to have receptorselective drugs for antiplatelet therapy [114].

Pepducins have been used to study the role of the chemokine receptors in sepsis and systemic inflammation and are found to improve survival and prevent systemic inflammation and overactivation of the coagulation system in sepsis. Pepducins corresponding to ICL1 and ICL3 of the chemokine receptors CXCR1 and CXCR2 function as selective antagonists of these receptors and inhibit $\mathrm{G}_{\mathrm{s}}$ mediated effects of interleukin-8, a ligand for these receptors, neutrophil chemotaxis toward interleukin-8 in particular, as well as reverse disseminated intravascular coagulation and liver failure in septic mice and prevent the lethal sequel of sepsis. At the same time, pepducins corresponding to ICL1 and ICL2 of the chemokine receptor CXCR4 selectively interact with their cognate receptors and cause a massive leukocytosis consistent with the role of CXCR4 in stromal-derived factor $1 \alpha$ neutrophil homeostasis, while the pepducins do not affect interleukin-8-mediated signaling pathways and have no effect on survival [100, 105].

We showed that peptide QVKKE(Nle)ILAKR ${ }^{619-629} \mathrm{~K}(\mathrm{Pal})$ corresponding to C-ICL3 of the $\mathrm{G}_{\mathrm{s}}$-coupled relaxin receptor RXFP1 stimulates AC activity and $\mathrm{G}_{\mathrm{s}}$ protein GTP binding and inhibits regulatory effects of relaxin on the AC system in the myocardium and brain, which raises no doubt due to a high level of expression of its cognate receptor, but is ineffective in the skeletal muscles where there are no receptors $[49,50]$. Palmitoylated peptide KHSRKALKASL ${ }^{258-268} \mathrm{~K}(\mathrm{Pal}) \mathrm{A}$ corresponding to C-ICL3 of $5-\mathrm{HT}_{6} \mathrm{R}$ is effective in the brain rich in $5-\mathrm{HT}_{6} \mathrm{R}$, but not in respect to the AC system in the myocardium and testes where these receptors are absent or expressed very little [39].

Alongside with high selectivity, pepducins are more efficient compared with their unmodified analogs. Actually, RXFP1-peptide 619-629-K(Pal) stimulates relaxin-sensitive AC system with greater efficiency compared with 15-mer peptide 615-629 lacking fatty acid radical, while unmodified 11-mer peptide is not active in this case [50]. Palmitoylated 5- $\mathrm{HT}_{6} \mathrm{R}$-peptide 258-268 has a stronger influence on $\mathrm{G}_{\mathrm{s}}$ proteins and AC than its unmodified analog [39]. PAR1peptide 295-313 lacking hydrophobic radical does not stimulate $\mathrm{Ca}^{2+}$ fluxes while its palmitoylated analog causes a rapid $\mathrm{Ca}^{2+}$ transient [97]. 
These data give grounds to make a conclusion that modification by hydrophobic radicals is one of the most perspective approaches to enhance both the selectivity and efficiency of GPCR-peptides as regulators of hormonal signaling systems. The main reason for high biological activity of pepducins is the ability of their hydrophobic radical to partition into the plasma membrane and to flip across lipid bilayer, thus shuttling the attached peptide to the intracellular surface of the membrane and mediating the effective interaction of peptide portion of pepducin with the complementary regions of the GPCR or G proteins [115].

\section{The Receptors with Tyrosine Kinase Activity}

In the 1990s the peptide strategy found wide application with a view to identify signal-protein-interacting regions in two best known receptors possessing tyrosine kinase activity, the insulin receptor (IR) and the EGF receptor. The IR belongs to the family of transmembrane glycoprotein receptors activated by insulin, insulin-like growth factor-1 and other insulin-related peptides, and is composed of two $135-\mathrm{kDa}$ extracellular $\alpha$ subunits which bind the hormone and two $95-\mathrm{kDa}$ transmembrane $\beta$ subunits with intrinsic tyrosine kinase activity. The main substrates of insulinstimulated phosphorylated IR are IRS and Shc proteins, but the data are available suggesting that IR is also able to interact with heterotrimeric $\mathrm{G}$ proteins and, thus, regulate $\mathrm{G}$ proteindependent signaling cascades $[11,15,116]$.

The first data concerning the regions capable of specifically interacting with $G$ proteins appeared in the early 1990 s and were obtained with three synthetic peptides, 1039-1061, 1135-1156, and 1319-1333, corresponding to the tyrosine kinase domain (the first two) and the C-terminal domain (the third) located in the cytoplasmic tail of IR $\beta$ subunit [117]. They contain positively charged BBXXB and the related motifs typical of $G$ protein-activating sequence of GPCRs. Peptide 1039-1061 induces a dose-dependent stimulation of GTP-binding and GTPase activities of $\mathrm{G}_{s}$ proteins, while peptide 1325-1345 containing a site for tyrosine phosphorylation located in the C-terminal domain of IR activates the $\mathrm{G}_{\mathrm{i} / \mathrm{o}}$ proteins [117], and peptide 11351156 containing tyrosine residues critical for IR tyrosine kinase activity stimulates GTP-binding of unusual $67 \mathrm{kDa}$ $\mathrm{G}$ protein involved in the insulin signal transduction [118]. The $\mathrm{G}_{\mathrm{i}}$-activating effect of C-terminal peptide $1325-1345$ is supported by the data obtained later on direct interaction between insulin-activated IR with $\mathrm{G}_{\mathrm{i} 2}$ protein and the blocking of this interaction by PT $[116,119]$.

To identify IR regions participating in phosphorylationdephosphorylation cascade, a series of peptides containing the most important tyrosine residues, the targets of tyrosine phosphorylation, and their derivatives with modified tyrosines were synthesized and studied (Table 1). A trissulfotyrosyl peptide 1142-1153 corresponding to the major site of autophosphorylation inhibits dephosphorylation of the IR in $\mathrm{CHO}$ cells overexpressing the human IR [67, 120]. An N-stearyl derivative of this peptide causes a several-fold increase in insulin- and vanadate-stimulated phosphorylation of IR and leads to a significant enhancement of insulin-induced stimulation of phosphatidylinositol 3-kinase (PI3-K) and mitogen-activated protein kinase (MAPK) activities but has no effect on the basal phosphorylation of IR. Maximal stimulation is observed with $50 \mu \mathrm{M}$ of $\mathrm{N}$-stearyl peptide 1142-1153. Peptide 12931307 corresponding to C-terminal domain of IR enhances insulin-stimulated receptor autophosphorylation but has no detectable effects on the basal phosphorylation of IR and on receptor dephosphorylation [68]. A stearyl analog of peptide 1293-1307 also enhances insulin-stimulated autophosphorylation and, additionally, induces a 2-3-fold increase in both the activity of insulin-stimulated PI3-K, and the level of tyrosine phosphorylation of MAPK in response to insulin. The most pronounced influence of N-stearyl derivatives of peptides 1142-1153 and 1293-1307 on insulininduced IR autophosphorylation and function, compared with unmodified analogs, suggests that the intrinsic activity of IR undergoes modulation, depending on the presence of a fatty acid-acylated receptor fragment in cells. The expression of a minigene encoding 23-mer peptide 1292-1315, the longest analog of peptide 1293-1307, has no effect on the basal receptor tyrosine phosphorylation level but leads to an increase in insulin-activated IR autophosphorylation that in minigene-transfected $\mathrm{CHO}$ cells is about twice as high as in control cells [121]. The stimulating effects of insulin on PI3-K and MAPK activities and thymidime incorporation into DNA are also significantly elevated in cells expressing the minigene. These data indicate that peptides 1142-1153 and 1293-1307 and minigene-expressed peptide 1292-1315 bind to the regions in IR $\beta$ subunit responsible for the intrinsic activity of the receptor and functional coupling with downstream signaling proteins, such as IRS and Shc proteins, PI3-K and MAPK. The action of the peptides and their lipophilic derivatives is highly specific since the latter are not capable of inhibiting dephosphorylation of EGF receptor and do not influence ligand-induced phosphorylation of both EGF receptor and insulin-like growth factor-1 receptor which functionally and structurally resembles IR $[67,68$, 121].

To identify the regions participating in IR tyrosine kinase function, Van Obbergen and colleagues used another approach based on antipeptide antibodies directed against synthetic peptides corresponding to the regions localized in the C-terminal domain of IR, such as 1270-1280, 1294-1317, and 1309-1326 [122-124]. Antipeptide IgG recognizing acid-rich sequence 1270-1280 inhibits both receptor autophosphorylation, at least on $\mathrm{Tyr}^{1146}$, $\mathrm{Tyr}^{1150}$, and $\mathrm{Tyr}^{1151}$, the main targets of IR tyrosine kinase, and the receptor-induced phosphorylation of $\operatorname{poly}\left(\mathrm{Glu}^{80} \mathrm{Tyr}^{20}\right)$ and a peptide corresponding to the region 1142-1158 [123]. The antipeptide antibody directed to the region 1294-1317 inhibits phosphorylation of $\operatorname{poly}\left(\mathrm{Glu}^{80} \mathrm{Tyr}^{20}\right)$ and synthetic peptides corresponding to the IR autophosphorylation sites but does not inhibit receptor autophosphorylation. In addition, it decreases receptor-mediated phosphorylation of Src homology/collagen and of IRS-1 protein by 52 and 30\%, respectively [124]. These data give strong evidence that the C-terminal domain of IR interacts with signal proteins 
participating in the regulation and modulation of tyrosine kinase activity of the receptor.

The EGF receptor one time penetrates the membrane and contains a large extracellular domain that consists of two ligand-binding and two cysteine-rich subdomains and the intracellular tyrosine kinase domain. The binding of EGF receptor to EGF causes receptor dimerization and induces phosphorylation of tyrosine residues in tyrosine kinase domain located in the intracellular tail of receptor, which recruits many signaling proteins, such as PI3-K, PLC- $\gamma$, PLD, Shc, and Grb2 proteins, phosphotyrosine phosphatase 1 , and others, and transduces hormonal signal to different intracellular effector proteins and systems [125]. In 1995 Sun and colleagues revealed that EGF receptor-derived peptide is able to stimulate G proteins [69] (Table 1). This finding coincides very well with the data obtained in the recent years about the direct interaction of different types of $\mathrm{G}$ proteins with EGF receptor and their role in EGF-mediated signaling $[11,126,127]$. The synthetic peptide 646-658 corresponding to the membrane-proximal segment of the juxtamembrane domain located in the cytoplasmic tail of EGF receptor stimulates GTP-binding and GTPase activities of $\mathrm{G}_{s}$ protein coupled to this receptor. In addition, it increases the $G_{i}$ protein GTPase activity without affecting the GTP-binding activity, which suggests that the juxtamembrane domain is able to stimulate $G_{s}$ proteins and inactivate $G_{i}$ proteins. Peptide with phosphorylated residue $\mathrm{Thr}^{654}$, the main target for protein kinase $\mathrm{C}(\mathrm{PKC})$, does not affect $\mathrm{G}_{s}$ protein and retains the ability to stimulate the GTPase activity of $G_{i}$ protein. The incorporation of negatively charged phosphate group decreases the net positive charge of peptide and, in addition, destabilizes its helical conformation, which is functionally important for effective interaction of peptide with the $G \alpha_{s}$ subunit, and, hence, blocks the activation of $\mathrm{G}_{\mathrm{s}}$ protein by the phosphorylated peptide. It is supposed that in the case of $G_{i}$ protein the phosphorylated peptide induces the dissociation of the heterotrimeric complex to give monomeric $\mathrm{G} \alpha_{\mathrm{i}}$ subunit and, thus, stimulates its GTPase activity. These data speak in favor of the fact that phosphorylation of tyrosine residues in EGF receptor, as well as of serine and threonine residues in GPCRs, affects selectively their coupling with different types of $G$ proteins, $G_{s}$ and $G_{i}$ proteins in particular. It was shown, in addition, that peptide 646-658 with the reverse sequence (RRLTRKRVIERRR) also activates $G_{s}$ protein, which indicates that orientation of peptide 646-658 is of no importance for its interaction with $\mathrm{G}$ protein and the main role in this process is given to the secondary structure of peptide ( $\alpha$ helix is optimal) and spatial distribution of positively charged amino acids [69]. As has been shown recently using the other biochemical approaches, $\mathrm{G} \alpha_{\mathrm{i} 1}$ and $\mathrm{G} \alpha_{\mathrm{i} 3}$ form the complex with ligandactivated EGF receptor and are required for phosphorylation of Grb2-associated binding protein 1 and its subsequent interaction with p85 subunit of PI3-K in response to EGF, whereas the coupling between EGF receptor and $\mathrm{G}_{s}$ protein leads to activation of cAMP-dependent signaling pathways $[11,127]$. Thus, the peptide strategy came to be a starting point for further investigations in which the role of $G$ proteins in the tyrosine kinase receptor-mediated signaling has been established.

A new era of application of the peptide strategy in the study of structural-functional organization of the tyrosine kinase receptors is connected with quantitative proteomics using pull-down experiments with pairs of phosphorylated and nonphosphorylated synthetic peptides, corresponding to phosphotyrosine-containing sites in the intracellular domains of these receptors $[13,128,129]$. The receptors possessing tyrosine kinase activity have, as a rule, several docking sites for each of the interacting proteins-partners. The EGF receptor and the related to it ErbB4 receptor have, for example, four to seven docking sites for Grb2 protein three to four sites for Shc protein, while ErbB3 receptor lacking the functional kinase domain has a large number of binding sites for PI3-K. Using a series of synthetic peptides corresponding to tyrosine phosphorylation sites of EGF and ErbB4 receptors, the new recognition motifs for Shc protein were detected. It was shown that the STAT5 protein, a latent cytoplasmic transcription factor, is a new partner of both receptors; it specifically interacts with $\mathrm{Tyr}^{978}$ - and $\mathrm{Tyr}^{998}$ containing sites of EGF receptor and with $\mathrm{Tyr}^{984}$-containing site of ErbB4 receptor. It should be pointed out that both phosphorylated and nonphosphorylated forms of peptides are used to study the role of tyrosine phosphorylation for effective and selective interaction of these receptors with their partners [129]. The assay based on the interaction between receptor-derived phosphotyrosine-containing peptides and proteins-partners is extremely specific and capable of conforming the binding motifs identified so far and detecting new target sequences, which is confirmed by the fact that all identified binding partners contain either SH2- or PTB-domains specifically interacting with phosphotyrosine-containing motifs, and phosphotyrosines not expected to have binding partners do not show any proteins with significant ratios. This assay is very sensitive, since the peptide-protein interaction screen is validated for binding constants as low as at least $5 \mu \mathrm{M}$, but it is likely to work with much lower affinity interactions $[128,129]$.

\section{Natriuretic Peptide Clearance Receptor}

The natriuretic peptide receptor of C-type (NPR-C) belongs to natriuretic peptide receptors but lacks gyanylyl cyclase catalytic domain. It is a disulfide-linked homodimer having a single TM, a large extracellular domain of 440 amino acids, and a short 37-amino acid cytoplasmic tail. The binding of the NPR-C with atrial natriuretic peptide (ANP) and its several fragments induces the activation of $G_{i}$ proteins and inhibition of AC activity and NPR-C-mediated decrease in cAMP levels contributes to the activation of PLC signaling [130].

A 37-mer peptide corresponding to the cytoplasmic tail of NPR-C and a similar peptide with 10 additional $\mathrm{N}$-terminal amino acids derived from receptor TM in a GTP-dependent manner inhibit AC activity in the cardiac membranes with $K_{i}$ of about $1 \mathrm{nM}$ [131]. Preincubation of the membranes with PT blocks AC inhibitory effect of peptides, which suggests that the latter, like ANP, inhibit the 
enzyme activity via PT-sensitive $\mathrm{G}_{\mathrm{i} / \mathrm{o}}$ proteins. To identify in the cytoplasmic domain of NPR-C the segments responsible for inhibition of AC activity the series of 8-18-mer peptides corresponding to different regions of this domain were synthesized and examined as regulators of the $\mathrm{G}_{\mathrm{i} / \mathrm{o}}$ proteins and $\mathrm{AC}$ activities [70, 132]. These peptides contain typical $\mathrm{G}_{\mathrm{i} / \mathrm{o}}$-activating sequences and have two basic amino acids at the $\mathrm{N}$ terminus and $\mathrm{BBXB}$ or $\mathrm{BBXXB}$ motifs at the $\mathrm{C}$ terminus [30, 133].

Pagano and Anand-Srivastava showed that positively charged peptides 461-472, 469-480, 469-485, and 481-492 in a concentration-dependent manner inhibit the basal AC activity with $K_{i}$ between 0.1 and $10 \mathrm{nM}$ and significantly decrease forskolin-, glucagon- and isoproterenol-stmulated AC activity in A-10 vascular smooth muscle cells and their inhibitory effects are completely attenuated by PT treatment [70] (Table 1). These peptides inhibit the stimulation of DNA synthesis induced by angiotensin II, endothelin, and arginine vasopressin but do not influence the basal level of DNA synthesis in these cells [72]. It was also shown that peptide 461-472 inhibits both the phosphorylation of ERK1/2 and AKT protein kinases and the increase of $\mathrm{G} \alpha_{\mathrm{i}}$ subunit expression induced by vasoactive peptide hormones. In addition, in the presence of this peptide the inhibitory effects of PD-98059, a MEK inhibitor, and of wortmannin, a PI3-K inhibitor, on hormone-induced DNA synthesis are potentiated. These data suggest that positively charged peptides containing $\mathrm{G}_{\mathrm{i} / \mathrm{o}}$-activating sequences, irrespective of their location within NPR-C cytoplasmic domain, inhibit proliferative responses of the muscle cells to vasoactive peptide hormones realized via $\mathrm{G}_{\mathrm{i} / \mathrm{o}}$ protein and MAPK/PI3K/AKT signaling pathways [72].

Murthy and Makhlouf [132] synthesized and studied the related peptides 467-482, 469-485, and 479-496 corresponding to the $\mathrm{N}$-terminal, middle, and $\mathrm{C}$-terminal regions of the intracellular domain of NPR-C. Peptide 469485, the same as the selective NPR-C agonist ANP(423), significantly increases the GTP binding to $\mathrm{G} \alpha_{\mathrm{i} 1}$ and $\mathrm{G} \alpha_{\mathrm{i} 2}$ subunits but not to $\mathrm{G} \alpha_{\mathrm{i} 3}, \mathrm{G} \alpha_{\mathrm{s}}$, and $\mathrm{G} \alpha_{\mathrm{q} / 11}$ subunits, stimulates phosphoinositide hydrolysis by activating PLC $\beta 3$ via the $G \beta \gamma$ subunits of both $G_{i 1}$ and $G_{i 2}$ proteins with an $\mathrm{EC}_{50}$ of $1.3 \mu \mathrm{M}$, and inhibits forskolin-stimulated $\mathrm{AC}$ activity by $64 \%$ in solubilized tenia coli smooth muscle membranes. In the presence of this peptide the stimulatory effects of $\mathrm{ANP}(4-23)$ on $\mathrm{G}_{\mathrm{i} 1}$ and $\mathrm{G}_{\mathrm{i} 2}$ proteins binding and the PLC $\beta 3$ activity are increased by 187,289 , and $43 \%$, respectively. Peptide 467-482 with a partial C-terminal BBXXB-motif is a less effective activator of the $G_{i 1}$ and $G_{i 2}$ proteins and PLC $\beta 3$. Peptide 479-496 does not influence the basal level of $\mathrm{G}$ protein binding and PLC activity but decreases the stimulatory effects of both $\operatorname{ANP}(4-23)$ and peptide $469-485$ on $\mathrm{G}_{\mathrm{i} 1}$ and $\mathrm{G}_{\mathrm{i} 2}$ proteins binding and PLC $\beta 3$ activity. Peptide 469-485 induces contraction in saponinpermeabilized smooth muscle cells and enhances the ability of ANP(4-23) to induce contraction. Peptide 479-496 has no effect on contraction but inhibits $\operatorname{ANP}(4-23)$-induced contraction. It follows that peptide 479-496 inhibits $\mathrm{G}_{\mathrm{i}}$ protein activation and cell responses mediated by $\operatorname{ANP}(4-$ 23) and peptide 469-485, suggesting that the positively charged motif KHRELR ${ }^{491-496}$ localized at the C-terminus of this peptide mediates binding but not activation of $\mathrm{G}$ protein, thus, causing peptide 479-496 to act as a competitive inhibitor of $G_{i}$ protein activation [132]. Summing up, using the synthetic peptides the selective $G_{i}$ protein-binding and -activating determinants within cytoplasmic tail of NPR$\mathrm{C}$ participating in activation of PLC-dependent signaling cascades responsible for muscle contraction were identified, which coincides very well with the later mutational and deletion studies [71].

\section{Heterotrimeric G Proteins}

Heterotrimeric $\mathrm{G}$ proteins consisting of $\alpha, \beta$, and $\gamma$ subunits are divided according to the nature of $\alpha$ subunit into four main families, $G_{s / o l f}, G_{i / o}, G_{q / 11}$, and $G_{12 / 13}$, based on structural and functional similarity [134]. In mammals there are $21 \mathrm{G} \alpha$ subunits encoded by 16 genes, six $\mathrm{G} \beta$ subunits encoded by five genes, and $12 \mathrm{G} \gamma$ subunits. G $\beta$ and $\mathrm{G} \gamma$ subunits form a functionally active $\mathrm{G} \beta \gamma$-heterodimeric complex; it anchors in the membrane and does not dissociate under nondenaturing conditions. $\mathrm{G}_{\mathrm{s}}$ proteins activate $\mathrm{AC}$ and calcium channels, $G_{i}$ proteins inhibit $A C$ and activate potassium channels, $G_{0}$ proteins stimulate PLC, activate potassium channels, and inactivate calcium channels, $G_{q / 11}$ proteins activate $\mathrm{PLC}$, and $\mathrm{G}_{12 / 13}$ proteins stimulate Rho/Rho kinase activity $[4,5,10]$.

Several different regions of $\mathrm{G} \alpha$ subunit are implicated in recognition of GPCRs and are responsible for the specificity of receptor- $G$ protein interaction, but the extreme C-terminal region is of special importance for effective and selective interaction of different types of $G$ proteins with ligand-activated GPCR [7, 42, 92, 94]. This negatively charged region of $\mathrm{G} \alpha$ binds with positively charged intracellular regions of GPCRs. It seems quite likely that GPCRs use C-terminal region as a "latch" to alter the conformation of the $\alpha 5$ helix of $\mathrm{G} \alpha$ subunit (Figure 2). The conformational changes of the $\alpha 5$ helix give rise to a change in the conformation of the $\beta 6 / \alpha 5$ loop, destabilize its contacts with the guanine ring of GDP, and lead to the GDP/GTP exchange [135]. In addition to the extreme C-terminus of $\mathrm{G} \alpha$, the $\alpha 4$ helix, and the $\alpha 4 / \beta 6$ loop, both localized close to the C-terminus, also directly participate in a receptor- $\mathrm{G}$ protein coupling and in the case of $\mathrm{G} \alpha$ i subunit determine its specificity [32]. It was shown that an anionic cluster of $\mathrm{G} \alpha$ i subunit $\alpha 4$ helix, especially negatively charged $\mathrm{Glu}^{308}$ and uncharged $\mathrm{Gln}^{304}$, directly interact with the positively charged region in ICL-3 of $\mathrm{G}_{\mathrm{i}}$-coupled $\mathrm{D}_{2}$-DR, and 5-HT $\mathrm{H}_{1 \mathrm{~A}} \mathrm{R}$ $[32,94]$. The replacement of the residues in $\mathrm{G} \alpha_{\mathrm{i} 1}$ subunit by the corresponding residues in $\mathrm{G} \alpha_{\mathrm{s}}\left(\mathrm{Q}^{304} \mathrm{R}\right.$ and $\left.\mathrm{E}^{208} \mathrm{~L}\right)$ leads to uncoupling mutant $\mathrm{G} \alpha \alpha_{\mathrm{i} 1}$ to $\mathrm{D}_{2}-\mathrm{DR}$, whereas the replacement of $\alpha 4$ helix residues in $\mathrm{G} \alpha$ s by the corresponding residues in $\mathrm{G} \alpha_{\mathrm{i} 1}\left(\mathrm{R}^{342} \mathrm{Q}\right.$ and $\left.\mathrm{L}^{346} \mathrm{E}\right)$ induces, on the contrary, activation of mutant $G \alpha_{s}$ by $D_{2}$-DR. It was shown also that peptides derived from N-ICL-3 of $\mathrm{G}_{\mathrm{i}}$-coupled $\mathrm{D}_{2}-\mathrm{DR}, 5-\mathrm{HT}_{1 \mathrm{~A}} \mathrm{R}$ and $\alpha_{2 \mathrm{~B}}$-AR give a 1.5-2.5-fold increase of GTP binding of the wild type of $\mathrm{G} \alpha_{\mathrm{i} 1}$ but have no effect on $\mathrm{G} \alpha_{\mathrm{i} 1}$ with paired mutation $\mathrm{Q}^{304} \mathrm{R} / \mathrm{E}^{208} \mathrm{~L}$. At the same time, having no influence on the GDP/GTP exchange of the wild type of G $\alpha_{\text {s }}$ they 


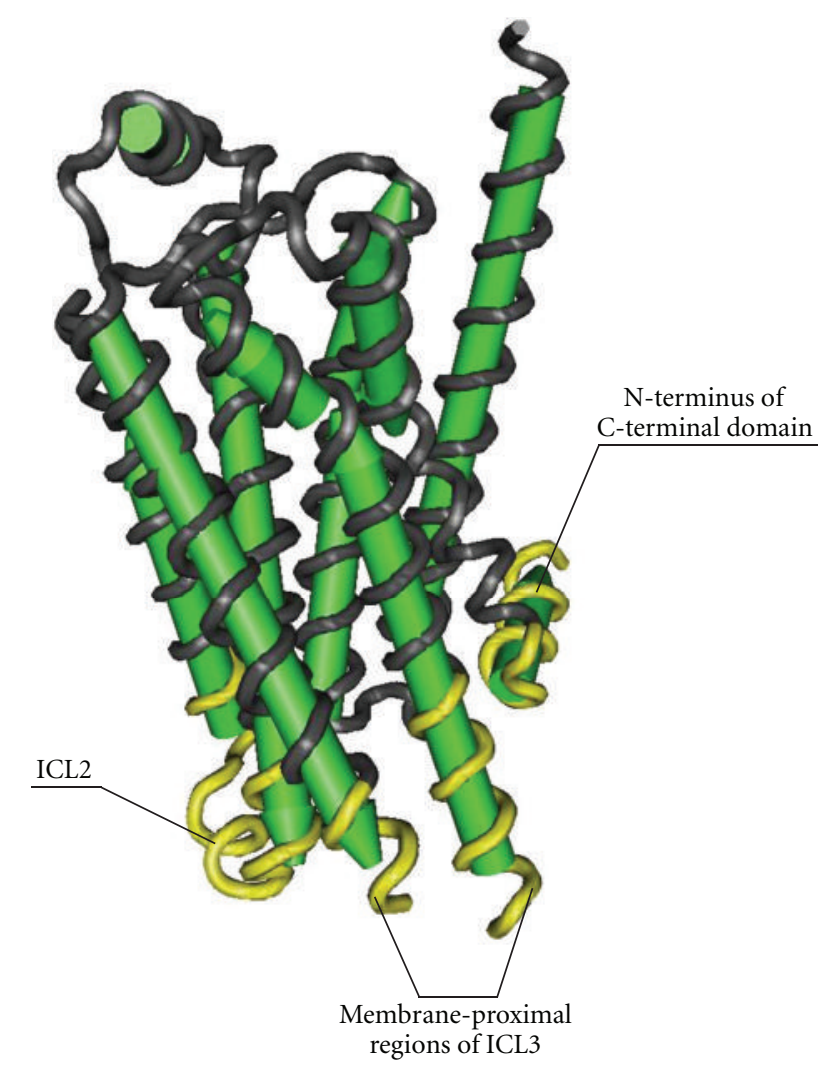

FIgURE 2: The intracellular regions of $G$ protein-coupled receptor of the serpentine type (yellow) participating in the interaction with heterotrimeric $\mathrm{G}$ proteins.

significantly increase GTP binding of the $\mathrm{G} \alpha_{\mathrm{s}}$ with mutation $\mathrm{R}^{342} \mathrm{Q} / \mathrm{L}^{346} \mathrm{E}$ [32]. The fact that all $\mathrm{G} \alpha_{\mathrm{i} / \mathrm{o}}$, unlike the other types of $\mathrm{G} \alpha$ subunits, have an anionic cluster in the $\alpha 4$ helices gives grounds to suggest that positively charged intracellular regions of $\mathrm{G}_{\mathrm{i} / \mathrm{o}}$-coupled GPCRs interact with two anionic regions of $\mathrm{G} \alpha_{\mathrm{i} / \mathrm{o}}$, the $\mathrm{C}$-terminus and the $\alpha 4$ helix, while the same regions of $\mathrm{G}_{\mathrm{s}^{-}}$and $\mathrm{G}_{\mathrm{q} / 11^{-} \text {-coupled GPCRs only }}$ with the C-terminus. Thus, the extreme C-terminus, the $\alpha 4$ helix and the $\alpha 4 / \beta 6$ loop of $\mathrm{G} \alpha$ subunit are responsible for its selective interaction with receptor and account for the ability of synthetic peptides corresponding to these regions to influence signal transduction via the cognate $G \alpha$ subunit.

Among the peptides derived from C-terminal region of the $\mathrm{G} \alpha$ subunits the best studied is the peptide $340-350$ of transducin $\mathrm{G} \alpha_{\mathrm{t}}$ subunit $[135,136]$ (Table 1). This peptide binds with photoactivated rhodopsin, meta-II-rhodopsin, and stabilizes the active signaling meta-II-rhodopsin conformation, thus mimicking the effects of transducin [73, 75]. Peptide 340-350 also interacts with meta-Ib-rhodopsin, another intermediate of light-activated receptor, forming a complex with inactive GDP-bound transducin, and with active G-protein-binding state of opsin, the ligand-free form of rhodopsin, stabilized at low $\mathrm{pH}[74,76]$.

The peptide interacts with the inner segments of TM5, TM6, TM7, and the N-terminus of the additional helix 8 of active forms of opsin [137-139]. The interaction between peptide 340-350 with Lys $^{341}$ replaced by leucine and the inner surface of TMC of rhodopsin leads to destruction of a hydrogen bond network which includes the side chains of $\mathrm{Arg}^{135}$ and $\mathrm{Glu}^{134}$ from the conserved E(D)RY motif localized in TM3/ICL2 interface and the side chains of Glu ${ }^{247}$ and $\mathrm{Thr}^{251}$ localized in cytoplasmic end of TM6. These events provoke the outward movement of TM6 and the formation of TM5-TM6 pair is stabilized by new interactions between the side chains of $\mathrm{Glu}^{247}$ and $\mathrm{Thr}^{251}$ of the TM6 that are released from $\operatorname{Arg}^{135}$ and the side chain of Lys $^{231}$ of the TM5. The peptide binding to rhodopsin is supposed to be rate-limited by the outward movement of TM6 [135]. The contacts with inner surface of the TM5 and TM6 induce a $\alpha$-helical conformation in peptide $340-350\left(\mathrm{~K}^{341} \mathrm{~L}\right)$ with a Cterminal reverse turn. The carbonyl groups in the reverse turn constitute the centre of a hydrogen-bonded network, which links the two receptor regions containing the $E(D) R Y$ motif and the conserved $\operatorname{NPxxY}(\mathrm{x})_{5,6} \mathrm{~F}$ motif connecting the TM7 and the helix 8.

The analogs of C-terminal peptide $340-350\left(\mathrm{~K}^{341} \mathrm{~L}\right)$ can stabilize meta-II-rhodopsin when they are covalently bound to one of the two native reactive cysteine residues, Cys ${ }^{140}$ and $\mathrm{Cys}^{316}$, localized on the intracellular surface of rhodopsin. Using synthetic peptides that differ in localization of a chemical crosslinking group, either at the $\mathrm{N}$-terminus or the C-terminus of peptide $340-350\left(\mathrm{~K}^{341} \mathrm{~L}\right)$, it was shown that the $\mathrm{N}$-terminus of peptide analog $\mathrm{M}-23 \mathrm{~S}$ is crosslinked to Cys $^{140}$ and the C-terminus of peptide analog B23S-IA to $\mathrm{Cys}^{316}$ [75]. The peptide M-23S crosslinking to the Cys ${ }^{140}$ localized on the cytoplasmic tip of TM3 and the peptide B23S-IA crosslinking to $\mathrm{Cys}^{316}$ localized in N-terminus of helix 8 are both necessary for stabilization of meta-IIrhodopsin. At the same time, peptide B23S-IA stabilizes the more compact meta-IIa-rhodopsin whereas peptide M-23S stabilizes meta-IIb-rhodopsin, protonation form of meta-IIrhodopsin capable of activating the $G$ protein [75].

Using IR-spectroscopy it was shown that negatively charged residues in the peptide 340-350 have a very important role in its interaction with rhodopsin [140]. Free carboxyl groups of $\mathrm{Glu}^{342}$ and $\mathrm{Asp}^{346}$ residues in $\mathrm{G} \alpha_{\mathrm{t}} \mathrm{C}$-terminal peptide subunit participate in specific binding with positively charged intracellular regions of rhodopsin. The elimination of the N-terminal positively charged amino group by $\mathrm{N}$ acylation of peptide 340-350 and delocalization of its positive charge replacing lysines by arginines increase the affinity of modified peptide for meta-II-rhodopsin, whereas amidation of the C-terminal negatively charged carboxyl group, on the contrary, reduces it [141]. The substitution of positively charged lysine by uncharged leucine greatly increases the affinity of peptide $340-350\left(\mathrm{~K}^{341} \mathrm{~L}\right)$, designated as 23S, for meta-II-rhodopsin and stabilizes its conformation [142]. Highly conservative in $\mathrm{G} \alpha_{\mathrm{t}}$ and $\mathrm{G} \alpha_{\mathrm{i} / \mathrm{o}}$ subunits Cys ${ }^{347}$ residue, the target for ADP-ribosylation by $\mathrm{PT}$, is involved in a hydrophobic interaction between peptide and meta-IIrhodopsin, since with the substitution of this cysteine by amino butyric acid, where the methylene-sulfhydryl group is replaced by an ethyl group the activity of the C-terminal peptide is maintained, whereas substitution by alanine gives a 3 -fold reduction in the meta-II-rhodopsin stabilizing activity 
of the peptide. Alongside with this, the modification of cysteine $\mathrm{SH}$-group by ribosyl radical brings about changes in the conformation of C-terminal region in full-size $\mathrm{G} \alpha_{\mathrm{t}}$ subunit as well as of peptide 340-350, which disturbs their interaction with rhodopsin.

It was shown that peptides, derivatives of C-terminal sites of the $\mathrm{G} \alpha_{s}$, very different in length disturb by the competitive mechanism the functional interaction of receptors and $G_{s}$ proteins and change the affinity of receptors for hormones $[66,77,143-151]$. The expression of 83-mer polypeptide derived from $\mathrm{C}$-terminal region of the $\mathrm{G} \alpha_{\mathrm{s}}$ induces the inhibition of $\beta_{2}$-AR- and $\mathrm{D}_{1 \mathrm{~A}}$-DR-mediated cAMP production in HEK293 cells [146]. Short synthetic peptides corresponding to progressively longer segments of the $\mathrm{G} \alpha{ }_{\mathrm{s}} \mathrm{C}$-terminus, 384$394,382-394,380-394,378-394\left(C^{379} \mathrm{~A}\right), 376-394\left(\mathrm{C}^{379} \mathrm{~A}\right)$, and $374-394\left(\mathrm{C}^{379} \mathrm{~A}\right)$, stimulate specific binding of selective agonist CGS21680 to the $\mathrm{G}_{\mathrm{s}}$-coupled $\mathrm{A}_{2 \mathrm{~A}}$-adenosine receptor in the rat striatal membranes both in the presence and in the absence of GTP $\gamma$ S, a nonhydrolysable GTP analog, which uncouples $G$ proteins from receptors (Table 1). The most effective peptides are $378-394\left(C^{379} \mathrm{~A}\right), 376-394\left(\mathrm{C}^{379} \mathrm{~A}\right)$, and $374-394\left(C^{379} A\right)$, and the shortest peptide $384-394$ is less active [77]. In accordance with the results of the study of $\mathrm{G} \alpha \alpha_{\mathrm{s}}$ crystal structure of the $\mathrm{G} \alpha$, the $\alpha 5$-helix responsible for effective interaction with the receptors involves the region from $\mathrm{Asp}^{368}$ to $\mathrm{Leu}^{394}$ [152]. Thus, the peptide containing 17 and more amino acid residues have a stronger propensity to assume an $\alpha$-helical conformation compared with the shortest peptides. The NMR analysis of 11-mer 384-394 and 21-mer 374-394(C379A) peptides was made and showed that both peptides demonstrate a marked propensity to form $\alpha$-helical structure in hexafluoroacetone/water, a mixture with structure stabilizing properties, peptide 384-394 having the shortest $\alpha$-helix between $\mathrm{Arg}^{389}$ and $\mathrm{Leu}^{394}$, and peptide $374-394\left(\mathrm{C}^{379} \mathrm{~A}\right)$, the longest $\alpha$-helix spanning region from $\mathrm{Asp}^{381}$ to $\mathrm{Leu}^{394}[77,153]$. The addition of the most active 21-mer 374-394 $\left(C^{379} A\right)$ peptide causes an increase of the number of binding sites but does not stabilize the highaffinity state of the $\mathrm{A}_{2 \mathrm{~A}}$-adenosine receptor. Peptide $374-$ $394\left(C^{379} \mathrm{~A}\right)$ inhibits agonist-stimulated AC activity by $35 \%$ and does not have a significant effect on the basal and forskolin-stimulated activities. This is the evidence that the peptide disrupts the signal transduction on the stage of coupling between agonist-activated $\mathrm{A}_{2 \mathrm{~A}}$-adenosine receptor and $G_{s}$ protein and does not interact directly with catalytic unit of AC [77].

A 37-mer peptidic constrain (A42) containing a 16-mer membrane-permeable sequence (MPS) of penetratin, derived from the homeodomain of the Drosophila melanogaster transcription factor Antennapedia that translocates through membranes, and a 21-mer peptide 374$394\left(C^{379} \mathrm{~A}\right)$ was designed and shown to have no affect on cell viability but to significantly inhibit adenosine receptormediated cAMP accumulation in PC12 cells with an $\mathrm{EC}_{50}$ of $5 \mu \mathrm{M}$ and decrease $\mathrm{A}_{2 \mathrm{~A}}$-adenosine receptor- and $\beta$-ARmediated cAMP production in human cell line HMEC-1 [151]. The maximal efficacy of NECA, a selective agonist of $\mathrm{A}_{2 \mathrm{~A}}$-adenosine receptor, is substantially reduced in the presence of A42 peptide suggesting that it competes with
$\mathrm{G} \alpha$ s for the interaction with receptor. The A42 peptide does not directly modulate AC activity and does not affect $\mathrm{G}_{\mathrm{i}^{-}}$and $\mathrm{G}_{\mathrm{q}}$-coupled receptor signaling, which indicates that the specific target for peptide is the receptor $G_{s}$-binding and -activating surface. Using NMR analysis it was shown that A42 peptide is arranged in two stretches of $\alpha$-helical structure encompassing sequences 3-10 and 18-36. Even in a membrane-mimicking environment and in conjugation with MPS, the segment 18-36 has the secondary structure resembling those of peptide $374-394\left(\mathrm{C}^{379} \mathrm{~A}\right)$ and of $\mathrm{C}$ terminal region in full-size $\mathrm{G} \alpha_{\mathrm{s}}$ [151]. The helix 18-36 is amphipathic and has a polar surface lined by $\mathrm{Asp}^{378}, \mathrm{Arg}^{390}$, $\mathrm{Asp}^{381}$, and $\mathrm{Arg}^{385}$ and two hydrophobic surfaces formed by less polar residues $\mathrm{Ile}^{382}, \mathrm{Ile}^{383}, \mathrm{Met}^{386}, \mathrm{Hi}^{387}, \mathrm{Tyr}^{391}$, and $\mathrm{Leu}^{393}$. The $\mathrm{N}$-terminal penetratin fragment of A42 peptide also possessing $\alpha$-helical structure has hydrophobic and hydrophilic residues forming clustered surfaces at the $\mathrm{N}$ terminus and in the center of the fragment and is responsible for peptide internalization by endocytosis.

The peptide strategy can be used to study the functional role of distinct amino acid residues in the C-terminus of $\mathrm{G} \alpha_{\mathrm{s}}$. The leucine residue localized at position $(-2)$ is absolutely invariant in $\mathrm{C}$-terminal regions of all $\mathrm{G} \alpha$ subunits. The substitution of this leucine (Leu ${ }^{393}$ ) with Ala, Phe, Lys, and D-Leu in C-terminal peptide 384-394 from the $\mathrm{G} \alpha$ s Cterminus gives modified peptides possessing much lower activity compared with unmodified peptide [147]. However, the peptides in which Leu ${ }^{393}$ was replaced by Asp and Thr retain a residual activity. The conformational analysis of peptides indicates that the side chain of $\mathrm{Leu}^{393}$, together with side chains of $\mathrm{Ile}^{382}$ and $\mathrm{Met}^{386}$, is involved in formation of a hydrophobic surface that is very important for effective interaction with the cognate receptor.

Minigene plasmids encoding 11-mer peptides corresponding to the C-terminal regions of $\mathrm{G} \alpha_{\mathrm{i}}, \mathrm{G} \alpha_{o}, \mathrm{G} \alpha_{\mathrm{q}}, \mathrm{G} \alpha_{12}$, and $\mathrm{G} \alpha_{13}$ have been successfully used to discern the contribution of different types of $\mathrm{G}$ proteins to signal transduction via $\mathrm{m}_{2}-\mathrm{MChR}$ and thrombin receptors [154-156]. Plasmid minigene vectors encoding the C-terminal sequence of $\mathrm{G} \alpha$ serve as competitive inhibitors presumably by blocking the $\mathrm{G}$ protein-binding site on the GPCR that normally binds the $\mathrm{G}$ protein. A minigene vector expressing the $\mathrm{G} \alpha_{\mathrm{i} 1 / 2} \mathrm{C}$ terminal peptide specifically inhibits $G_{i 1 / 2}$ protein inwardly rectifying $\mathrm{K}^{+}$channel activity following agonist stimulation of the $\mathrm{m}_{2}-\mathrm{MChR}$ and decreases thrombin-induced inhibition of AC activity in endothelial cells $[154,155]$. The minigene vectors expressing the $\mathrm{G} \alpha_{\mathrm{o}}$ and $\mathrm{G} \alpha_{\mathrm{q}} \mathrm{C}$-terminal peptides in a competitive manner block the coupling between $\mathrm{G}_{\mathrm{o}}$ and $\mathrm{G}_{\mathrm{q}}$ proteins and the human thromboxane $\mathrm{A}_{2}$ receptor $\left(\mathrm{TXA}_{2} \mathrm{R}\right)$; they significantly decrease thrombin-stimulated intracellular $\mathrm{Ca}^{2+}$ level and inhibit the stimulatory effects of thrombin on PLC activity; as a result $\mathrm{PI} 1,4,5-\mathrm{P}_{3}$ production is blocked $[155,156]$. The minigenes encoding the C-terminal peptides of $G_{12}$ and $G_{13}$ proteins decrease thrombin-stimulated stress fiber formation that is mediated via $G_{12 / 13}$ protein family [155]. A minigene encoding mutated C-terminal sequence of $\mathrm{G}_{\mathrm{q}}$ protein, in which two C-terminal residues, Ala and Val, are replaced by the Thr and Lys, has a little effect on thrombin-induced PLC activity, and even partially restores 
the response of the enzyme decreased in the presence of wild $\mathrm{G} \alpha_{\mathrm{q}}$ C-terminal peptide [155]. A minigene expressing 15mer peptide of $\mathrm{G} \alpha_{\mathrm{q}} \mathrm{C}$-terminal region, the same as 11-mer peptide, inhibits thrombin-stimulated PLC activity, and, in addition, specifically binds to ligand-free $\mathrm{TXA}_{2} \mathrm{R}$ with high affinity $\left(K_{d}\right.$ is $\left.17 \mu \mathrm{M}\right)$ and to agonist-activated receptor with low affinity $\left(K_{d}\right.$ is $\left.240 \mu \mathrm{M}\right)$ [157]. It is a clear indication that the $\mathrm{C}$-terminal region of $\mathrm{G} \alpha_{\mathrm{q}}$ binds to $\mathrm{TXA}_{2} \mathrm{R}$ without agonist, which suggests the existence of a preoccupied $\mathrm{G}$ protein-binding site on the intracellular domains of ligandfree $\mathrm{TXA}_{2} \mathrm{R}$. The action of minigenes is very specific, being realized that provided hormonal responses are mediated via their cognate $G$ proteins. The above is the evidence that the use of minigene-based peptide strategy not only confirms the view that each $G$ protein can control certain signaling events but also emphasizes, in addition, the specificity of the GPCR$\mathrm{G}$ protein interface. Thus, the minigenes encoding $\mathrm{G} \alpha \mathrm{C}$ terminal regions appear to be a powerful tool for dissecting out the $G$ protein that mediates a given physiological function following thrombin activation.

As mentioned above for $\mathrm{G} \alpha_{\mathrm{s}}$-derived $\mathrm{A} 42$ peptidic constrain containing the MPS, the efficiency of G $\alpha$ Cterminal peptides depends on the ability of the latter to penetrate the plasma membrane. A shorter peptide 350-359 corresponding to the extreme $\mathrm{C}$ terminus of $\mathrm{G} \alpha_{\mathrm{q}}$ modified by MPS corresponding to Kaposi fibroblast growth factor signal region inhibits $5-\mathrm{HT}_{2 \mathrm{C}} \mathrm{R}$-mediated signaling in cultured choroids plexus epithelial cells significantly decreasing serotonin-stimulated PLC activity, whereas its unmodified membrane-impermeable analog is unable to disrupt the functional coupling between agonist-activated $5-\mathrm{HT}_{2 \mathrm{C}} \mathrm{R}$ and $\mathrm{G}_{\mathrm{q}}$ protein [145]. A peptide 385-394, derivative of the C terminus of $\mathrm{G} \alpha_{\mathrm{s}}$, modified by this MPS at the $\mathrm{N}$-terminus significantly decreases, to almost basal level, $\beta_{2}$-AR agonistinduced stimulation of AC activity in astrocytes, whereas the nonconjugated analog that is unable to penetrate the plasma membrane has low inhibitory activity. It should be pointed out that Kaposi fibroblast growth factor-derived MPS alone is inactive; therefore its contribution in the blockade of any signal cascade tested is hardly of great importance. However, it is not always the case. We showed that several polycationic peptides used as MPSs can have influence on the activity of the components of hormonal signaling systems, G proteins and $\mathrm{AC}$ in particular, and their action must be taken into account in developing cell-penetrating conjugates on the basis of these peptides [51, 158-160].

The interaction of $G$ proteins with the effector enzymes, $\mathrm{AC}$ in particular, is also very important for deciphering the molecular mechanisms of GPCR-mediated signal transduction. Proceeding from the data that the crystal structure of $\mathrm{G} \alpha_{\mathrm{s}}$ complexed with the soluble functional fragments of $\mathrm{AC}$ shows three regions localized in $\mathrm{G} \alpha_{\mathrm{s}}$, all having a direct contact with the enzyme [161], three peptides 199$216,222-247$, and 268-286 corresponding to these regions were synthesized and their influence on the activity of the types 2 and 6 ACs studied [78] (Table 1). An 18-mer peptide 199-216 encoding the Switch I region from $\mathrm{G} \alpha_{\mathrm{s}}$ stimulates the basal and forskolin-stimulated activities of AC2 as well as AC6, and forskolin does not appear to shift the peptide concentration-effect curves. This peptide also inhibits the $\mathrm{G} \alpha_{\mathrm{s}}$-stimulated activity of both isoforms of the enzymes by about $30 \%$ and, thus, behaves as a partial agonist. At the same time, the analogous peptide with the substitutions $\mathrm{G}^{206} \mathrm{P}, \mathrm{I}^{207} \mathrm{D}, \mathrm{E}^{209} \mathrm{~K}$, and $\mathrm{K}^{211} \mathrm{~A}$ has no effect on $\mathrm{AC} 2$ and AC6 activities. The residue $\mathrm{Ile}^{207}$ of $\mathrm{G} \alpha_{\mathrm{s}}$ makes a contact with AC while the residues $\mathrm{Gly}^{206}$, Glu ${ }^{209}$, and $\mathrm{Lys}^{211}$ are responsible for appropriate local conformation of the Switch I region. Peptide 222-247 encoding the Switch II region, the same as peptide 199-216, stimulates the basal activity of both AC isoforms making it 2-3 times higher, significantly increases forskolin-stimulated AC activity, and inhibits $\mathrm{G} \alpha_{\mathrm{s}}$ stimulated AC activity by 30-35\%. Peptides 199-224 and 204-229 encoding the Switch II regions of the $\mathrm{G} \alpha_{\mathrm{i}}$ and $\mathrm{G} \alpha_{\mathrm{q}}$, respectively, that structurally are very similar to the Switch II region of $\mathrm{G} \alpha$ s are not capable of stimulating the $\mathrm{AC}$ activity [78]. The effects of peptides 199-216 and 222-247 on the activity of AC2 are additive at lower concentrations giving a left-shifted curve but are not additive at saturating concentrations. A different effect is observed for AC6 where peptide 222-247 lowers the effect of peptide 199-224. In the case of AC2 the stimulating effect of peptide 199-224 is stronger compared with that of peptide $222-247$ while in the case of AC6 the effect of peptide 222-247 predominates. Now a suggestion can be put forward that the molecular mechanisms underlying interaction of the Switch regions of $\mathrm{G} \alpha_{\mathrm{s}}$ and $\mathrm{AC}$ isoforms are not all alike. Peptide 268-286 corresponding to $\alpha 3-\beta 5$ region that interacts with the Cterminal tail as well as with the central cytoplasmic loop of AC inhibits the basal and forskolin-stimulated activities of both enzymes by about $30 \%$ and, in addition, significantly decreases the $\mathrm{G} \alpha_{\mathrm{s}}$-stimulated AC activity. Potent inhibition of the $\mathrm{G} \alpha_{\mathrm{s}}$-stimulated activity by peptide $268-286$ indicates that $\alpha 3-\beta 5$ is involved in stabilization of the appropriate orientation of the Switch regions required for effective AC activation. The peptide with the highly conservative residues $\operatorname{Trp}{ }^{277}$ and $\operatorname{Trp}^{280}$ replaced by Arg and Lys, respectively, has no influence on AC activity [78]. Studying the $G \alpha_{\mathrm{s}^{-}}$ derived peptides, specific functions of different regions of $\mathrm{G} \alpha_{\mathrm{s}}$ directly contacting AC were revealed.

\section{Adenylyl Cyclases}

Mammalian membrane-bound ACs producing the second messenger cAMP in response to $G_{s}$ protein stimulation are represented by at least nine different isoforms (AC1-AC9) and possess two hydrophobic transmembrane regions, each built up by six TM and two pseudosymmetric cytosolic domains $C_{1}$ and $C_{2}$ that comprise subdomains $C_{a}$ and $\mathrm{C}_{\mathrm{b}}$. All AC subtypes are stimulated by GTP-bound $\mathrm{G} \alpha_{\mathrm{s}}$ and diterpene forskolin, $\mathrm{AC} 1$ by $\mathrm{Ca}^{2+}$-calmodulin $(\mathrm{CaM})$, AC2 by $\mathrm{G} \beta \gamma$-dimer, while AC5, and AC6 are inhibited by submicromolar concentrations of $\mathrm{Ca}^{2+}$ and AC1, AC5 and AC6 by GTP-bound $\mathrm{G} \alpha$ i subunit. Synthetic peptides are widely used for identification of the regions in AC cytoplasmic domains involved in the functional interaction with the regulatory proteins and responsible for the enzyme activity [79-81] (Table 1). 
To determine the role of various interaction regions within the $\mathrm{C}_{1}$ and $\mathrm{C}_{2}$ domains of the AC2 and AC6 in the

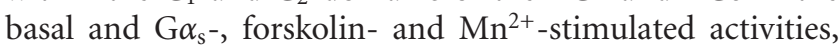
five peptides corresponding to different interface regions involved in interaction with each other were synthesized [81]. Two peptides, $427-444$ and 487-511, correspond to $\alpha 2$ $\beta 2-\beta 3$ and $\beta 4-\beta 5-\alpha 4$ regions of the $\mathrm{C}_{1}$ domain of $\mathrm{AC} 6$, and three peptides, 899-926, 927-948, and 984-1015, to $\alpha 2, \beta 2$ $\beta 3$, and $\alpha 3-\beta 4$ regions of the $\mathrm{C}_{2}$ domain of $\mathrm{AC} 2$, respectively. All these peptides inhibit both $\mathrm{G} \alpha_{\mathrm{s}}$ - and forskolin-stimulated activities of full-length AC2 and AC6 expressed in Hi5 cells. Peptides 487-511 and 984-1015 also inhibit basal activity by $30 \%$. Peptide $899-926$ encoding $C_{2}$ domain $\alpha 2$ region inhibits the basal and $\mathrm{Mn}^{2+}$-stimulated activities of AC2 and AC6 by $52-59 \%$, and $\mathrm{G} \alpha_{s^{-}}$and forskolin-stimulated activities of the enzymes by $55-63$ and $71-80 \%$, respectively. The other peptides do not affect $\mathrm{Mn}^{2+}$-stimulated activities significantly. The peptides with the replacement of residues most important in the interaction with other amino acids in the $\mathrm{C}_{1}$ and $\mathrm{C}_{2}$ domains, such as $427-444\left(\mathrm{R}^{434} \mathrm{D}, \mathrm{K}^{436} \mathrm{D}\right.$, $\left.\mathrm{I}^{437} \mathrm{P}\right), 487-511\left(\mathrm{G}^{498} \mathrm{P}, \mathrm{K}^{501} \mathrm{E}, \mathrm{Q}^{503} \mathrm{R}\right),{ }^{899-926}\left(\mathrm{E}^{910} \mathrm{~K}, \mathrm{R}^{913} \mathrm{P}\right.$, $\left.\mathrm{N}^{916} \mathrm{~A}, \mathrm{E}^{917} \mathrm{~K}, \mathrm{~L}^{926} \mathrm{~S}\right),{ }^{927-948}\left(\mathrm{~K}^{936} \mathrm{D}, \mathrm{I}^{937} \mathrm{~F}, \mathrm{~K}^{938} \mathrm{D}, \mathrm{T}^{939} \mathrm{~F}\right.$, $\left.\mathrm{I}^{940} \mathrm{~F}\right)$, and $984-1015\left(\mathrm{H}^{989} \mathrm{D}, \mathrm{F}^{991} \mathrm{~K}, \mathrm{~N}^{992} \mathrm{~K}, \mathrm{~K}^{995} \mathrm{G}, \mathrm{I}^{1010} \mathrm{D}\right.$, $\mathrm{G}^{1011} \mathrm{D}, \mathrm{A}^{1012} \mathrm{Q}, \mathrm{Q}^{1013} \mathrm{~K}$ ) have no influence on the enzyme activity. Thus, the peptide strategy suggests that the AC activity stimulated by different regulators involves distinct interface interactions in the full-length enzyme, which indicates that the AC may have multiple catalytically competent configurations [81].

To identify CaM-binding regions in CaM-regulated $\mathrm{AC} 1$ and to decipher the molecular mechanisms of CaM regulatory action on the enzyme activity, the peptides corresponding to $\mathrm{C}_{1 \mathrm{~b}}$ subdomain region $495-522$ (pAC28) of $\mathrm{AC} 1$ and $\mathrm{C}_{2 \mathrm{a}}$ subdomain region 1024-1044 (pVLG) of AC1 were synthesized $[79,80]$. The peptide pAC28 exhibits a high affinity for CaM binding $\left(K_{d}, 2 \mathrm{nM}\right)$ and inhibits CaM-stimulated AC activity with $\mathrm{IC}_{50}$ equal to $500 \mathrm{nM}$ [79]. The peptide pVLG binds CaM with low affinity and inhibits CaM-stimulated $\mathrm{AC}$ activity with $\mathrm{IC}_{50}$ equal to $10 \mu \mathrm{M}$, which points to a minor role of the region $1024-1044$ in CaM-mediated stimulation of AC1 activity compared with the region 495-522. However, despite its rather high affinity for $\mathrm{CaM}$, the peptide pAC28 binds to $\mathrm{CaM}$ in a $\mathrm{Ca}^{2+}$-independent manner, although the modulation of $\mathrm{AC} 1$ activity by $\mathrm{CaM}$ is known to be very $\mathrm{Ca}^{2+}$-dependent. At the same time, the peptide pVLG binds to CaM in a $\mathrm{Ca}^{2+}$ dependent manner. These data speak in favor of the fact that CaM requires not only $\mathrm{Ca}^{2+}$-independent $\mathrm{C}_{1 \mathrm{~b}}$ subdomain region 495-522 but also $\mathrm{Ca}^{2+}$-dependent $\mathrm{C}_{2 \mathrm{a}}$ subdomain region 1024-1044 to stimulate AC1. When two CaM-critical residues of the peptide pVLG, $\mathrm{Val}^{1027}$ and $\mathrm{Leu}^{1030}$, are replaced by alanines, the specific binding of modified peptide pAAG with CaM is significantly reduced and the peptide pAAG competes with AC for CaM less efficiently than the peptide pVLG, pointing to a sequence dependence of the region 1024-1044 for binding to CaM. Thus, despite the structural and functional variety and different recognizing motifs on $\mathrm{AC}$, CaM, like $\mathrm{G} \alpha_{\mathrm{s}}$ and $\mathrm{G} \beta \gamma$ subunits, and forskolin, modulates the enzyme activity according to a two-site-interaction mechanism [80]. The peptide pVLG, in addition to inhibiting CaM-stimulated AC activity, also decreases the basal activity of AC1. The peptide pAAG having the inactive amino acid substitutions is also able to inhibit the enzyme activity. This is likely to be due to the interaction of peptide 1024-1044 with complementary region forming catalytic and/or regulatory sites of AC1 in CaM-free state.

\section{The Family of Phospholipases C}

Inositol-specific PLCs are the family of $\mathrm{Ca}^{2+}$-dependent multidomain enzymes, represented in mammalian cells by several isoforms, such as PLC $\beta$, PLC $\gamma$, PLC $\delta$, PLCE, PLC $\zeta$, and PLC $\eta$. They catalyze the hydrolysis of phosphatidylinositol 4,5-diphosphate (PI 4,5- $\mathrm{P}_{2}$ ) to yield diacylglycerol and phosphatidylinositol 1,4,5-triphosphate (PI 1,4,5- $\mathrm{P}_{3}$ ), which are important secondary messengers. PI $1,4,5-\mathrm{P}_{3}$ binds to its receptor in the endoplasmic reticulum to open $\mathrm{Ca}^{2+}$ channels which increases the intracellular level of $\mathrm{Ca}^{2+}$ and activates calcium-sensitive enzymes, such as protein kinase C (PKC) $[162,163]$. The PLC activity is regulated by many hormones and growth factors that realize their effects through GPCRs, receptor tyrosine kinases, and small G-proteins of the Ras and Rho families. These enzymes are implicated in intracellular signal transduction, vesicle transport, endocytosis, exocytosis, regulation of the ionic channels functions, mitosis, and cytoskeletal reorganization.

The family of PLC $\beta$, the major effectors of $G_{q}$ proteins, consists of four members different in their response to $G$ proteins. The PLC $\beta 1$, for instance, is activated by GTPbound $\mathrm{G} \alpha_{\mathrm{q}}$ subunit and is insensitive to $\mathrm{G} \beta \gamma$ dimer, and the activity of PLC $\beta 2$, on the contrary, is regulated by G $\beta \gamma$ dimer. The PLC $\beta 1$ is expressed as two splice variants, PLC $\beta 1$ a and PLC $\beta 1 \mathrm{~b}$, differing only in the extreme C-terminal sequences, 75 amino acid residues in PLC $\beta 1 \mathrm{a}$ and 32 in PLC $\beta 1 \mathrm{~b}$. The PLC $\beta 1 \mathrm{a}$ is localized in the cytoplasm, whereas PLC $\beta 1 \mathrm{~b}$ is associated with the sarcolemmal membrane, but deletion of the entire unique 31-mer sequence causes cytosolic localization of mutant PLC $\beta 1 \mathrm{~b}$. Using synthetic peptides it was found that the critical role in association with the membrane has a short 10-mer C-terminal segment of PLC $\beta 1 \mathrm{~b}$ that determines functional activity of the enzyme [82] (Table 1). A myristoylated peptide corresponding to this segment of PLC $\beta 1 \mathrm{~b}$ enriched by proline residues induces the dissociation of the enzyme from the sarcolemmal membrane and inhibits its response to $\alpha_{1}$-AR agonists with $\mathrm{EC}_{50}$ of $12 \mu \mathrm{M}$, whereas the same peptide from the C-terminus of PLC $\beta 1$ a taken as control is ineffective. Later it was shown that a 32-mer C-terminal peptide of PLC $\beta 1 \mathrm{~b}$ competes with full-size enzyme for sarcolemmal localization and inhibits PLC activity stimulated by bsoth $\alpha_{1}$-AR agonist norepinephrine and expressing constitutively active $\mathrm{G} \alpha_{\mathrm{q}}$ [83]. A 32-mer PLC $\beta 1$ b-peptide significantly decreases a substantial hypertrophic response induced by phenylephrine and mutant $\mathrm{G} \alpha_{\mathrm{q}}$ subunit. So, PLC $\beta 1 \mathrm{~b}$-peptides preventing the enzyme association with the sarcolemma and inhibiting signal transduction via $\mathrm{G}_{\mathrm{q}}$-coupled receptors downstream of $\mathrm{G}_{\mathrm{q}}$ activation may provide useful therapeutic agents for the treatment of hypertrophy and other cardiomyocyte damages. 
The inhibition of hypertrophic signal transduction may be also achieved using the peptides, derivatives of $G \alpha_{\mathrm{q}}$, that are able to prevent pressure overload hypertrophy and to delay the progression of heart failure $[164,165]$. However, the inhibition of $\mathrm{G}_{\mathrm{q}}$-coupled signaling pathways involved in control of fundamental cellular processes at the level of $G_{q}$ protein far from being an ideal strategy because it can induce numerous dysfunctions in these pathways and, therefore, the selective inhibition or stimulation of GPCR or the enzyme, the generators of second messengers, PLC $\beta 1$ in particular, is preferable in this case.

The PLC $\beta$-peptides are used for identification of the $G$ protein-interacting regions in $\operatorname{PLC} \beta[145,166]$. The PLC $\beta 1$-peptide 1053-1084 modified at the N-terminus by MPS corresponding to Kaposi fibroblast growth factor signal region in a dose-dependent manner inhibits GTP $\gamma \mathrm{S}$ dependent activation of PLC $\beta 1$ in both purified PLC $\beta 1$ and crude membrane preparations containing the intact enzyme, which indicates the disruption of the functional interaction between PLC $\beta 1$ and $G \alpha_{\mathrm{q}}$ in active, GTP-bound, form [145]. Peptides 564-583 and 574-593 corresponding to the central region of PLC $\beta 2$ specifically bind to G $\beta \gamma$ and inhibit $\mathrm{G} \beta \gamma$-mediated stimulation of the enzyme activity [166]. Moreover, peptide $564-583$ is more active compared with peptide 574-593, which speaks in favor of the fact that region 564-583 contains all determinants required for effective G $\beta \gamma$ dimer binding. The modification of peptide 564-583 with MPS does not influence their binding properties but increases its ability to block $\mathrm{G} \beta \gamma$-mediated activation of the enzyme activity in cultured cells [145].

The PLC $\beta$-peptides are appropriate tools for identification of the enzyme isoforms participating in signal transduction triggered by different hormones that activate $\mathrm{G}_{\mathrm{q}}$ - and $\mathrm{G}_{\mathrm{i} / \mathrm{o}}$-coupled GPCRs $[84,145]$. The PLC $\beta 1$-peptide 1053-1084 modified by MPS blocks, down to the basal level, serotonin-induced phosphatidylinositol hydrolysis in cultured choroids plexus epithelial cells, where $\mathrm{G}_{\mathrm{q}}$-coupled $5-\mathrm{HT}_{2 \mathrm{C}} \mathrm{R}$ is the main mediator of serotonin stimulation. The inhibitory effect of peptide MPS-1053-1084 is dosedependent with $\mathrm{IC}_{50}$ equal to $55 \mu \mathrm{M}$. The PLC $\beta 2$-peptide MPS-564-583 does not significantly influence $5-\mathrm{HT}_{2 \mathrm{C}} \mathrm{R}$ mediated stimulation of phosphatidylinositol hydrolysis. These data indicate that serotonin-induced activation of the 5- $\mathrm{HT}_{2 \mathrm{C}} \mathrm{R}$ leads to the release of active $\mathrm{G} \alpha_{\mathrm{q}}$ subunit and its interaction with PLC $\beta 1$ specifically regulated by $G \alpha_{\mathrm{q}}$, but not with PLC $\beta 2$ regulated by G $\beta \gamma$ dimer [145]. The same happens in the case of metabotropic glutamate receptors (mGluRs). At concentration $300 \mu \mathrm{M}$ peptide MPS-10531084 significantly inhibits phosphatidylinositol hydrolysis stimulated by 3,5-dihydrophenylglycine, a specific agonist of the types 1 and 5 mGluR (mGluR1 and mGluR5), in primary cultures of astrocytes where $\mathrm{G}_{\mathrm{q}}$-coupled mGluR5 is expressed. In contrast, the treatment of the cells with peptide MPS-564-583 does not decrease the stimulation of mGluR-mediated phosphatidylinositol hydrolysis. These data suggest that mGluR5-mediated signaling is involved in PLC $\beta 1$ activated by $\mathrm{G} \alpha_{\mathrm{q}}[145]$.

Microinjection of heptapeptide 1161-1167 corresponding to the extreme C-terminal region of PLC $\beta 3$ in the cytoplasm of the HN33 hippocampal cells leads to a significant decrease of calcium signaling induced by mGluR agonist N-1,3-cyclopentanedicarboxylic acid [84] (Table 1). Injection with the same C-terminal peptides of other PLC $\beta$ isozymes, such as PLC $\beta 1, \operatorname{PLC} \beta 2$, and PLC $\beta 4$, does not cause any changes in the calcium signaling. As according to the available data, the C-terminus of the PLC $\beta 3$ binds to adaptor and regulatory proteins, a PDZ domain-containing multimodular scaffolding protein Shank/ProSAP in particular, mediating the interaction between ligand-activated mGluR, $\mathrm{G}_{\mathrm{q}}$ protein, and PLC $\beta 3$ at highly specialized submembranous sites, it can be assumed that peptide 1161-1167 competes with the enzyme for binding with these proteins and, thus, inhibits the transduction of a hormonal signal from the receptor to the enzyme [84].

The membrane-permeable PLC $\beta$-peptides, specifically binding $\mathrm{G} \alpha_{\mathrm{q}}$ and $\mathrm{G} \beta \gamma$, can be used to study the involvement of these subunits in PLC-independent signaling pathways [145]. Pretreatment of HEK cells expressing the $\mathrm{G}_{\mathrm{i} / \mathrm{o}}$-coupled $\alpha_{2 \mathrm{~A}}$-AR with PLC $\beta 2$-peptide MPS-564-583 that specifically binds $\mathrm{G} \beta \gamma$ dimer completely blocks the activation of MAPK by epinephrine through $\alpha_{2 \mathrm{~A}}$-AR, while the PLC $\beta 1$-peptide MPS-1053-1084 specifically interacting with $\mathrm{G} \alpha_{\mathrm{q}}$ does not affect $\alpha_{2 \mathrm{~A}}$-AR-mediated MAPK activation. Unlike this, pretreatment of HEK cells expressing the $\mathrm{G}_{\mathrm{q}}$-coupled thrombin receptor with MPS-1053-1084 blocks the subsequent activation of PLC $\beta$ by thrombin receptor-activating peptide, but peptide MPS-564-583 in this case is ineffective. These data show that activation of MAPK cascade by $\alpha_{2 \mathrm{~A}}$-AR agonists is mediated through $\mathrm{G} \beta \gamma$ subunits released from the $\mathrm{G}_{\mathrm{i} / \mathrm{o}}$ proteins, while the PLC $\beta$ activation by thrombin receptor agonists involves $G \alpha_{q}$, but not $G \beta \gamma$, which coincides with the data obtained using the other methods [145].

Studying synthetic peptides corresponding to different loci of PLC $\delta 1$, putative CaM-binding motif 473-493 of IQ type (VQXXXKXXXXK) was identified in the $\mathrm{X} / \mathrm{Y}$ linker region of the enzyme that was not detected in the other PLC isoforms [86] (Table 1). Peptide 473-493 in a competition manner inhibits the binding of CaM with PLC $\delta 1$, but only in two cases, either in the absence of or at low concentrations of $\mathrm{Ca}^{2+}$. The binding of CaM to peptide 473-493 is, indeed, inversely related to $\mathrm{Ca}^{2+}$ concentration, while the peptide coprecipitates PLC $\delta 1$ irrespective of $\mathrm{Ca}^{2+}$ concentration. The incubation of PLC $\delta 1$ with $10-100 \mu \mathrm{M}$ of the peptide causes a $22-53 \%$ reduction in the ability of PLC $\delta 1$ to catalyze hydrolysis of PI 4,5- $\mathrm{P}_{2}$. The results obtained with peptide 473-493 show that CaM binds with putative IQ motif located within the catalytic site of PLC $\delta 1$ and inhibits the enzyme activity [86].

In Sertoli cells FSH induces an immediate $\mathrm{Ca}^{2+}$ influx

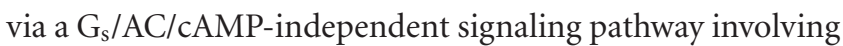
PLC $\delta 1$ and tissue transglutaminase possessing GTP-binding and GTPase activities and designated as $G \alpha_{\mathrm{h}}$ [167]. The myristoylated peptide corresponding to region $747-763$ of PLC $\delta 1$ in a competition manner inhibits the enzyme activity acting on the stage of coupling between FSH-stimulated $\mathrm{G} \alpha_{\mathrm{h}}$ protein and PLC $\delta 1$, while U73122, a specific nonpeptidic inhibitor of PLC, directly interacts with the enzyme and blocks its translocation from cytosol to the plasma 
membrane, which is necessary for $\mathrm{PI} 1,4,5-\mathrm{P}_{3}$ production (Table 1). The pretreatment of rat Sertoli cells with 0.1 and $1 \mu \mathrm{M}$ of the peptide leads to a 50 and $90 \%$ reduction of FSH-induced intracellular PI $1,4,5-\mathrm{P}_{3}$ generation and to a 35 and $70 \%$ reduction of the $\mathrm{FSH}$-evoked $\mathrm{Ca}^{2+}$ influx, which demonstrates a critical role of $\mathrm{G} \alpha_{\mathrm{h}} / \mathrm{PLC} \delta 1 / \mathrm{PI} 1,4,5-$ $\mathrm{P}_{3}$ pathway in the $\mathrm{FSH}$-induced $\mathrm{Ca}^{2+}$ influx in Sertoli cells $[87,167]$. The action of the peptide is pathway-specific, since it does not interfere with FSH-induced activation of $\mathrm{G}_{s} / \mathrm{AC}$ signaling pathway leading to an increase of the intracellular cAMP level.

The PLC $\gamma$ participates in the signal cascades involving tyrosine kinase receptors, that is, brain-derived neurotrophic factor receptors and nerve growth factor receptors, and nonreceptor tyrosine kinases, for example, B-cell receptors and T-cell receptors, as the sensor components, and scaffolding molecules, Bruton's tyrosine kinase in particular, that mediate the functional coupling between ligandactivated receptor proteins and PLCy [168]. As is known, the PLC $\gamma$ contains adjacent to its $\mathrm{SH} 2$ and $\mathrm{SH} 3$ domains a PLC inhibitor (PCI) region, including a positively charged segment YRKMRLRY, that strongly suppresses PI 4,5- $\mathrm{P}_{2}$ hydrolyzing activity. Synthetic peptides identical to the PCI region inhibit the enzyme activity induced not only by PLC $\gamma$, but also by PLC $\beta$ and PLC- $\delta$ [169]. In addition, they inhibit $\mathrm{Ca}^{2+}$-dependent PLC activation in digitonin-permeabilized cells and agonist- and GTP $\gamma$ S-dependent PLC activation in purified plasma membranes [170]. The modification of PCIpeptide $724-736$ by the conjugating myristic acid at the $\mathrm{N}$ terminus increases its PLC inhibitory effects in vitro [85] (Table 1). The $K_{i}$ values are 120 and $3.5 \mu \mathrm{M}$ for unmodified peptide 724-736 and its myristoylated analog, respectively. Myristoylated peptide 724-736 at concentrations in the submicromolar range significantly suppresses in vitro $\mathrm{PI} 1,4,5-\mathrm{P}_{3}$ formation induced by hormones and growth factors (EGF, PDGF, bombesin) in Swiss $3 \mathrm{~T} 3$ fibroblasts (the $\mathrm{IC}_{50}$ values are rather low, approximately $1 \mu \mathrm{M}$ ) and strongly inhibits cell proliferation induced by these stimuli in vivo in erbB-, $v$-rafand B-raf-transformed NIH 3T3 cells, neutrophils, isolated pancreatic cells, and Swiss 3T3 fibroblasts. This indicates that myristoylation of PCI-peptides leads to structural alteration, resulting in their effective entry into substrate-containing vesicles and close association with PLC. The inhibitory effects on the basal PLC activity and hormone-stimulated PI 1,4,5$\mathrm{P}_{3}$ formation and proliferation of $\mathrm{N}$-myristoylated peptide 724-736 with the replacement of the $\mathrm{Tyr}^{726}$ and $\mathrm{Tyr}^{734}$ by phenylalanines are much less potent than the effects of the original myristoylated peptide. This gives grounds to say that biological activity of PCI-peptides depends to a large extent on tyrosine residues [85]. There is one thing to be mentioned at this point that unmodified peptide 724-736 with the Y726F/Y734F replacement is not active at all.

\section{Phosphatidylinositol 3-Kinase}

Heterodimeric PI3-K consisting of regulatory p85 and catalytic p110 subunits generates phosphoinositide second messengers, such as phosphatidylinositol 3,4,5-triphosphate (PI 3,4,5- $\mathrm{P}_{3}$ ) and phosphatidylinositol 3,4-diphosphate (PI
3,4- $\mathrm{P}_{2}$ ), and regulates an array of signaling pathways through the membrane recruitment and activation of downstream effector proteins [171]. It was shown that C-terminal $\mathrm{SH} 2$ domain of PI3-K p85 $\alpha$ subunit contains $\mathrm{PI} 3,4,5-\mathrm{P}_{3}$-binding region 18-29 and displays discriminative affinity for this phosphoinositide, depending on the length of acyl chain and the charge density on the phosphoinositol ring of PI 3,4,5$\mathrm{P}_{3}$. Peptide 11-29 including the region selectively binds $\mathrm{PI}$ 3,4,5- $\mathrm{P}_{3}$ with $K_{d}$ of $30 \mu \mathrm{M}$, as in the case of the full-length C-terminal $\mathrm{SH} 2$ domain, but has the binding affinity for other phosphoinositides, PI 3,4- $\mathrm{P}_{2}$ in particular, which is one to two orders of magnitude lower compared with PI 3,4,5- $\mathrm{P}_{3}$ [88] (Table 1). This peptide in a dose-dependent manner inhibits the binding of $\left[{ }^{3} \mathrm{H}\right]$ di- $\mathrm{C}_{8}-\mathrm{PI} 3,4,5-\mathrm{P}_{3}$ to the full-length C-terminal SH2 domain of PI3-K p85 $\alpha$ subunit immobilized onto streptavidin-coated beads with $\mathrm{IC}_{50}$ of $62 \mu \mathrm{M}$. On the addition of PI 3,4,5- $\mathrm{P}_{3}$ the contribution of $\alpha$-helical conformation in the peptide structure increases significantly. Besides, confirming the fact that the binding site for PI 3,4,5- $\mathrm{P}_{3}$ is localized within region $11-29$, these findings suggest that the other regions of p85 subunit are not involved in this binding [88].

\section{Protein Kinase C}

The family of the PKCs, intracellular serine/threonine protein kinases, includes classical forms of the enzymes (PKC $\alpha$, $\mathrm{PKC} \beta$, and $\mathrm{PKC} \gamma$ ) undergoing activation in the presence of diacylglycerol and calcium ions, novel isoforms of PKC $(\delta, \varepsilon, \eta, \theta)$ independent of $\mathrm{Ca}^{2+}$ regulation, and atypical PKC isoforms $(\zeta, \iota)$ independent of diacylglycerol and $\mathrm{Ca}^{2+}$ [172]. All PKCs possess C-terminal serine/threonine protein kinase domain linked to a regulatory domain including an inhibitory region, designated as the pseudosubstrate site [173]. As is known, PKCs are inactive in the absence of activating agents owing to an intramolercular interaction between a short inhibitory sequence located in the pseudosubstrate site and the substrate-binding region of the catalytic domain. Synthetic peptides corresponding to pseudosubstrate inhibitory sequence selectively decrease functional activity of PKC $[174,175]$. To penetrate into cell pseudosubstrate peptides were subjected to modification using MPS derived from Antennapedia protein or HIV1 TAT protein and hydrophobic fatty acid radicals [89, $176,177]$. As a rule, such modification has no influence on cellular processes, neither does it change the spectrum of inhibitory properties of pseudosubstrate peptides. However, cell-permeable pseudosubstrate peptides from $\mathrm{PKC} \alpha / \beta$, $\mathrm{PKC} \eta, \mathrm{PKC} \zeta$, and kinase domain of EGF receptor modified by myristoyl radical, in addition to inhibiting PKC activity, possess the ability to activate ERK1/2 and p38 MAPK, the components of MAPK cascade, and the intracellular enzymes (AKT kinase, in particular) involved in endothelial nitric oxide synthase activation and NO production $[89,178]$ (Table 1). Because an increase of endothelial nitric oxide synthase activity seems beneficial in the case of many diseases such as ischemic stroke, hypertension, and atherosclerosis, PKC-derived myristoylated peptides have a good chance to 
be used as pharmacological compounds for acute activation of the enzyme.

\section{The Molecular Mechanisms of Action of Intracellular Signal Protein-Derived Peptides}

According to the present view, there may be three molecular mechanisms of action of signal protein-derived peptides, all including different models of the competition relationships between the peptide and its cognate signal proteins.

The first mechanism is based on the competition between the peptide and its cognate full-length signal protein for the interaction with the other functionally and structurally complementary signal and proteins, components of signaling cascade. According to this mechanism, GPCR-peptide directly interacts with $G$ protein subunits, $G \alpha$ or $G \beta \gamma$; $\mathrm{G} \alpha$-peptide with the $\mathrm{G} \beta \gamma$-dimer complex, the receptor or the enzyme generating the second messenger; AC-derived peptide with $\mathrm{G}$ protein or AC-competent regulatory proteins, $\mathrm{CaM}$ in particular; and so on. This creates conditions for GPCR-peptide corresponding to $G$ protein-activating region of the receptor to activate $G$ proteins in a dosedependent manner and trigger coupled to them signaling cascades and in a competition manner to disturb functional interaction between its cognate ligand-activated receptor and $\mathrm{G}$ proteins, decreasing or completely blocking the signal transduction. Then GPCR-peptide will function as antagonist of GPCR-signaling. A peptide corresponding to the extreme C-terminal region of $\mathrm{G} \alpha$ subunit binds to $\mathrm{G}$ protein-activating region of GPCR and selectively inhibits the transduction of hormonal signal from ligand-activated receptor to its cognate $\mathrm{G}$ proteins, acting also as antagonist of signal transduction. The peptide, derivative of the Cterminal region of the PLC $\beta 3$, competes with the full-size enzyme for binding with adaptor and regulatory proteins, including scaffolding protein Shank/ProSAP, which leads to destabilization of functionally active receptor- $\mathrm{G}_{\mathrm{q}}$ proteinPLC $\beta 3$ complex and to inhibition of hormone-induced stimulation of phosphoinositide hydrolysis [84].

The second mechanism includes the interaction of synthetic peptide with complementary regions of protein homologous to it. According to Covic and colleagues, this mechanism accounts for the ability of pepducins to activate or, contrary to this, to inhibit signal transduction via their cognate receptor [97]. When pepducin acts as agonist, it binds to the high-affinity activating site formed by the intracellular regions of GPCR and, thus, stabilizes or induces the active state of receptor, which makes it possible for the latter to interact effectively with $G$ proteins and trigger signaling cascade. When pepducin acts as antagonist, it binds to loweraffinity inhibiting site that blocks the interaction between ligand-activated receptor and $G$ protein and prevents the transduction of signal to $G$ protein. According to this twosite mechanism, GPCR-peptide specifically interacts with complementary regions of its cognate receptor that in intact receptor have contacts with the region homologous to the peptide affecting their mobility and rearrangement. The peptides corresponding to various regions within the $\mathrm{C}_{1}$ and $\mathrm{C}_{2}$ domains of the AC2 and AC6 differ in the ability to influence the basal and forskolin-, $\mathrm{G}_{\mathrm{s}^{-}}$and $\mathrm{Mn}^{2+}$-stimulated activities, which indicates that these peptides interact with different complementary regions forming catalytic and regulatory site of the enzyme.

The data obtained in our and the other authors' investigations show that the receptor specificity of GPCR-peptides and the dependence of their action on the receptors homologous to them unambiguously speak in favor of the second mechanism of action of GPCR-peptides [26, 39, 50, 97]. The receptor specificity and the need in cognate receptor are likely to be both responsible for participation of the cognate receptor in realization of regulatory effects of GPCRpeptides, which resembles the action of signal proteinderived peptides carried out by the second mechanism.

The data about high receptor specificity of pepducins, the lipidated GPCR-peptides, are mentioned before. Studying 5-HTR-derived peptides we found that they affect only their cognate 5-HTR and practically do no influence the activity of structurally close to them 5-HTRs [39]. $5-\mathrm{HT}_{6} \mathrm{R}-$ peptide 258-268 reduces the stimulating effects of serotonin and, to a greater extent, EMD-386088, a selective $5-\mathrm{HT}_{6} \mathrm{R}$ agonist, on AC activity and $\mathrm{G}_{s}$ proteins GTP binding. At the same time, the agonists of the other types of 5-HTR, which are also able to stimulate AC system, still have such effects. The inhibitory effect of peptide $258-268$ on serotonin signaling is blocked in the presence of $5-\mathrm{HT}_{6} \mathrm{R}$ antagonists SB-271046 and methiothepin but is retained in the presence of antagonists of the other types of 5-HTR. 5- $\mathrm{HT}_{1 \mathrm{~B}} \mathrm{R}$-peptide 300-316 decreases AC inhibiting effects of serotonin and 5$\mathrm{HT}_{1} \mathrm{R}$ agonists, especially of selective $5-\mathrm{HT}_{1 \mathrm{~B}} \mathrm{R}$ agonist 5nonyloxytryptamine, and their stimulating effects on the $\mathrm{G}_{\mathrm{i}}$ proteins, while the effects of agonists of the other types of 5HTR in the presence of this peptide do not change. $5-\mathrm{HT}_{1 \mathrm{~B}} \mathrm{R}$ antagonists reduce or completely block the effects of peptide 300-316, whereas the antagonists of the other types of 5HTR in this case are not effective [39].

As mentioned above, the action of P1pal-19 corresponding to N-ICL3 of PAR1 on PLC $\beta$ and the other downstream effector enzymes is partially or completely blocked in cultured cells and tissues where the cognate PAR1 is absent. Peptide P1pal-19 and its analogs are ineffective in the presence of the mutant PAR1 entirely devoid of CTD. It follows that activation of the $\mathrm{G}$ proteins by $\mathrm{P} 1$ pal- 19 requires the presence of the CTD of the receptor and it may provide a binding site for PAR1-derived pepducins [98]. Peptide 615629 derived from relaxin receptor RXFP1 stimulates the basal $\mathrm{AC}$ activity in the rat myocardium and brain with abundant RXFP1 receptors, but it does not affect the enzyme activity in the skeletal muscles [50], where relaxin regulates $\mathrm{AC}$ via the receptor of a different type [179]. The action of 5-HTRpeptides on AC system is well expressed in the brain, the main target of serotonin, and rather little in the muscle and reproductive tissues, where the 5-HTRs are expressed weakly or not at all [39].

The third mechanism of action of signal protein-derived peptides is based on their ability to influence the stability of homo- and heteromeric complexes formed by their cognate 
proteins, which in many cases accounts for the functional activity of these proteins. It is shown that the cyclic peptide 225-273 constructed on the basis of a full-size ICL3 of the $\mathrm{V}_{2}$-vasopressin receptor induces a significant inhibition of the bioluminescence resonance energy-transfer signal between constrains $V_{2}$ receptor-luciferase and $V_{2}$ receptoryellow fluorescent protein, indicating that it modifies the distance and/or orientation between these constrains engaged in formation of dimeric complex and, thus, causes a dosedependent decrease in specific binding of $\left[\mathrm{Arg}^{8}\right]$-vasopressin as a result of transition of the receptor high-affinity to lowaffinity state and inhibits vasopressin-induced stimulation of AC activity [55]. Peptide 260-276 corresponding to CICL3 of $\mathrm{D}_{2}$-DR also affects the stability of the heterodimeric complex between $\mathrm{D}_{1}$ - and $\mathrm{D}_{2}-\mathrm{DR}$, which leads to alteration of dopamine signaling in the brain [32, 40, 42]. There is a view that peptide competes with its corresponding region in intact $\mathrm{D}_{2}$-DR containing a positively charged segment RRRRKR ${ }^{217-222}$ for binding to the anionic site located in CTD of $\mathrm{D}_{1}-\mathrm{DR}$ and prevents the $\mathrm{D}_{1} / \mathrm{D}_{2}$-heterodimerization. So, GPCR-peptides change the stability of receptor complex and are capable of acting either as positive allosteric regulators inducing the appropriate cellular response to agonist even at a very low concentration or as negative allosteric regulators blocking partially or completely this response.

Concerning the mechanism of action of signal proteinderived peptides realized in the cell, it is likely be a combination of the above mechanisms, depending on the structure of the peptide and localization of the region homologous to it in cognate protein, the modification of peptides by hydrophobic radicals and functional groups, the ability of signal proteins to form intermolecular complex, and other things. Finally, the choice between the first and the second mechanisms has a direct relation to the affinity of peptide for the proteins homologous to it or the proteins-partners functionally interacting with the latter. If the affinity of synthetic peptide for complementary regions of the cognate protein is higher than that for those of other proteins, the preference is given to the second mechanism; if the affinity for complementary regions of other proteins specifically interacting with the cognate protein is above that for the latter, the first mechanism comes into action, as a rule. The affinity depends not only on structural-functional features of synthetic peptides and full-length signal proteins but also on the physical-chemical properties of the medium $(\mathrm{pH}$, salts, polar and non-polar solvents, etc.), the presence of hydrophobic surfaces, microenvironment of signal proteins, and other factors.

\section{Conclusion}

Many approaches are used now to study hormonal signaling systems and to develop specific and selective regulators controlling their functional activity; the peptide strategy, however, has some advantages compared to the others. First, the length of biologically active signal protein-derived peptides does not usually precede 15-20 amino acid residues, and they can be synthesized in a short time and in quantum satis, using the solid-phase method, purified to homogeneity by reversed phase HPLC and characterized by massspectrometry, amino acid analysis, and other appropriate methods. Second, to enhance biological activity and selectivity of the action of peptides and to obtain their analogs with higher stability to hydrolytic enzymes, signal protein-derived peptides are subjected to different modifications, such as selective blocking of free functional groups of amino acids, substitution of L- by D-amino acids and of natural amino acids by rare, nonnatural, amino acids, synthesis of cyclic and branched forms of peptides and their di- and oligomeric constrains, and attachment to them of hydrophobic radicals. Third, to obtain cell-penetrating forms of peptides, the latter can be cross-linked either with the MPS represented by short polycationic segment containing five or more arginine residues, the amphiphilic helix having hydrophilic positively charged side with lysine residues, often-applicable sequence 48-60 of HIV-1 TAT protein and signal sequence of Kaposi fibroblast growth factor, or modified by the hydrophobic moiety such as hydrophobic TM helical segment, hydrophobic fatty acid, and steroid radicals mimicking TM of intact signal protein. In the recent years in the synthesis of peptides wide application has found the minigene approach, a new biotechnology method in the frame of the peptide strategy. This approach is very perspective for the synthesis of very long peptides corresponding to full-length subdomains of signal proteins as well as of chimeric constrains including combination of regions derived from different signal proteins, but it is not applicable for obtaining modified by Dand nonnatural amino acids, branched and oligomeric as well as cell-penetrating forms of the signal protein-derived peptides, and cannot be used with all cell types. At the same time, a further modification of the minigene approach with the aim to expand its applicability must go on, especially because it allows creation of a whole library of signalprotein-derived peptides for deciphering a complex network of intracellular signal cascades and their selective regulation and modulation. It is of special importance that the minigene approach can be used to control the function of the central nervous system, where small minigene-expressing peptides may serve as selective intracellular regulators and modulators of neuronal signal transmission.

It should be said in conclusion that on the addition to peptides derived from signal proteins, the components of hormone-sensitive signaling systems, some peptides generated from nonsignal proteins are also able to selectively regulate and modulate cell signaling, acting as a kind of bioactive molecules within cells [180]. These peptides are released in large amount by proteasomes and other extralysosomal proteolytic systems and before complete degradation can interfere with signal protein interaction, thereby affecting signal transduction, gene regulation, metabolism, protein targeting, and apoptosis. In pathological conditions a change in the composition of these intracellular nonsignal proteinderived peptides can have influence on the activity of hormonal signaling systems, especially their downstream components, and lead to disturbances in cell homeostasis. 


\section{Abbreviations}

\begin{tabular}{|c|c|}
\hline AC: & Adenylyl cyclase \\
\hline ANP: & Atrial natriuretic peptide \\
\hline AR: & Adrenergic receptor \\
\hline CaM: & Calmodulin \\
\hline CTD: & C-terminal domain \\
\hline DR: & Dopamine receptor \\
\hline EGF: & Epidermal growth factor \\
\hline FSH: & Follicle-stimulating hormone \\
\hline GLP1R: & $\begin{array}{l}\text { Glucagon-like peptide-1 } \\
\text { receptor }\end{array}$ \\
\hline GPCR: & G protein-coupled receptor \\
\hline 5-HTR: & $\begin{array}{l}\text { 5-hydroxytryptamine } \\
\text { receptors }\end{array}$ \\
\hline ICL1, ICL2, and ICL3: & $\begin{array}{l}\text { The first, second and third } \\
\text { intracellular loops; }\end{array}$ \\
\hline IR: & Insulin receptor \\
\hline MAPK: & $\begin{array}{l}\text { Mitogen-activated protein } \\
\text { kinase }\end{array}$ \\
\hline MChR: & $\begin{array}{l}\text { Muscarinic acetylcholine } \\
\text { receptor }\end{array}$ \\
\hline mGluR: & $\begin{array}{l}\text { Metabotropic glutamate } \\
\text { receptor }\end{array}$ \\
\hline MPS: & $\begin{array}{l}\text { Membrane-permeable } \\
\text { sequence }\end{array}$ \\
\hline N-CTD: & N-terminal region of CTD \\
\hline N- and C-ICL3: & $\begin{array}{l}\mathrm{N}-\text { and } \mathrm{C} \text {-terminal regions of } \\
\text { ICL3 }\end{array}$ \\
\hline NPR-C: & $\begin{array}{l}\text { Natriuretic peptide clearance } \\
\text { receptor of C-type }\end{array}$ \\
\hline PAR: & Protease-activated receptor \\
\hline PCI: & PLC inhibitor \\
\hline PI3-K: & Phosphatidylinositol 3-kinase \\
\hline $\mathrm{PI} 3,4-\mathrm{P}_{2}$ and PI 4,5- $\mathrm{P}_{2}$ : & $\begin{array}{l}\text { Phosphatidylinositol 3,4- and } \\
\text { 4,5-diphosphates; }\end{array}$ \\
\hline PI 1,4,5-P $\mathrm{P}_{3}$ and PI 3,4,5- $\mathrm{P}_{3}$ : & $\begin{array}{l}\text { Phosphatidylinositol 1,4,5- } \\
\text { and 3,4,5-triphosphate }\end{array}$ \\
\hline PKC: & Protein kinase $\mathrm{C}$ \\
\hline PLC and PLD: & Phospholipases C and D \\
\hline PT: & Pertussis toxin \\
\hline S1P: & Sphingosine-1-phosphate \\
\hline TM: & Transmembrane region \\
\hline TMC: & Transmembrane channel \\
\hline $\mathrm{TXA}_{2} \mathrm{R}:$ & Thromboxane $\mathrm{A}_{2}$ receptor. \\
\hline
\end{tabular}

\section{Acknowledgments}

This work was supported by Grant no. 09-04-00746 from the Russian Foundation of Basic Research. The author is grateful to Inga Menina for linguistic assistance.

\section{References}

[1] A. C. Conner, J. Simms, J. Barwell, M. Wheatley, and D. R. Poyner, "Ligand binding and activation of the CGRP receptor," Biochemical Society Transactions, vol. 35, no. 4, pp. 729 732, 2007.
[2] K. P. Hofmann, P. Scheerer, P. W. Hildebrand et al., "A G protein-coupled receptor at work: the rhodopsin model," Trends in Biochemical Sciences, vol. 34, no. 11, pp. 540-552, 2009.

[3] H. Zheng, H. H. Loh, and P. Y. Law, "Agonist-selective signaling of $\mathrm{G}$ protein-coupled receptor: mechanisms and implications," International Union of Biochemistry and Molecular Biology Life, vol. 62, no. 2, pp. 112-119, 2010.

[4] A. V. Smrcka, "G protein $\beta \gamma$ subunits: central mediators of G protein-coupled receptor signaling," Cellular and Molecular Life Sciences, vol. 65, no. 14, pp. 2191-2214, 2008.

[5] D. J. Dupré, M. Robitaille, R. V. Rebois, and T. E. Hébert, "The role of $\mathrm{G} \beta \gamma$ subunits in the organization, assembly, and function of GPCR signaling complexes," Annual Review of Pharmacology and Toxicology, vol. 49, pp. 31-56, 2009.

[6] A. Woehler and E. G. Ponimaskin, "G protein-mediated signaling: same receptor, multiple effectors," Current Molecular Pharmacology, vol. 2, no. 3, pp. 237-248, 2009.

[7] T. M. Cabrera-Vera, J. Vanhauwe, T. O. Thomas et al., "Insights into $\mathrm{G}$ protein structure, function and regulation," Endocrine Reviews, vol. 24, no. 6, pp. 765-781, 2003.

[8] C. R. McCudden, M. D. Hains, R. J. Kimple, D. P. Siderovski, and F. S. Willard, "G-protein signaling: back to the future," Cellular and Molecular Life Sciences, vol. 62, no. 5, pp. 551577, 2005.

[9] C. A. Johnston and D. P. Siderovski, "Receptor-mediated activation of heterotrimeric G-proteins: current structural insights," Molecular Pharmacology, vol. 72, no. 2, pp. 219230, 2007.

[10] S. R. Sprang, Z. Chen, and X. Du, "Structural basis of effector regulation and signal termination in heterotrimeric G $\alpha$ proteins," Advances in Protein Chemistry, vol. 74, pp. 165, 2007.

[11] T. B. Patel, "Single transmembrane spanning heterotrimeric G protein-coupled receptors and their signaling cascades," Pharmacological Reviews, vol. 56, no. 3, pp. 371-385, 2004.

[12] L. Plum, M. Schubert, and J. C. Brüning, "The role of insulin receptor signaling in the brain," Trends in Endocrinology and Metabolism, vol. 16, no. 2, pp. 59-65, 2005.

[13] S. Morandell, T. Stasyk, S. Skvortsov, S. Ascher, and L. A. Huber, "Quantitative proteomics and phosphoproteomics reveal novel insights into complexity and dynamics of the EGFR signaling network," Proteomics, vol. 8, no. 21, pp. 4383-4401, 2008.

[14] A. O. Shpakov, "The homology of the primary structure of the third cytoplasmic domains in rhodopsin-type receptors and of the cytoplasmic tail in the $\beta$-subunit of the insulin receptor," Tsitologiia, vol. 38, no. 11, pp. 1179-1190, 1996 (Russian).

[15] M. N. Pertseva, A. O. Shpakov, S. A. Plesneva, and L. A. Kuznetsova, "A novel view on the mechanisms of action of insulin and other insulin superfamily peptides: involvement of adenylyl cyclase signaling system," Comparative Biochemistry and Physiology, vol. 134, no. 1, pp. 11-36, 2003.

[16] A. O. Shpakov and M. N. Pertseva, "The peptide strategy as a novel approach to the study of $\mathrm{G}$ protein-coupled signaling systems," in Signal Transduction Research Trend, N. O. Grachevsky, Ed., pp. 45-93, Nova Science Publishers, New York, NY, USA, 2007.

[17] K. Palczewski, T. Kumasaka, T. Hori et al., "Crystal structure of rhodopsin: a G protein-coupled receptor," Science, vol. 289, no. 5480, pp. 739-745, 2000.

[18] J. Bockaert, P. Marin, A. Dumuis, and L. Fagni, "The "magic tail" of G protein-coupled receptors: an anchorage 
for functional protein networks," Federation of the Societies of Biochemistry and Molecular Biology Letters, vol. 546, no. 1, pp. 65-72, 2003.

[19] T. W. Schwartz, T. M. Frimurer, B. Holst, M. M. Rosenkilde, and C. E. Elling, "Molecular mechanism of 7TM receptor activation-a global toggle switch model," Annual Review of Pharmacology and Toxicology, vol. 46, pp. 481-519, 2006.

[20] H. R. Bourne, "How receptors talk to trimeric G proteins," Current Opinion in Cell Biology, vol. 9, no. 2, pp. 134-142, 1997.

[21] J. Wess, "G-protein-coupled receptors: molecular mechanisms involved in receptor activation and selectivity of Gprotein recognition," Federation of American Societies for Experimental Biology Journal, vol. 11, no. 5, pp. 346-354, 1997.

[22] A. O. Shpakov, "Molecular basis of the functional coupling of receptors to GTP-binding proteins," Membrane and Cell Biology, vol. 9, no. 5, pp. 467-487, 1996.

[23] A. O. Shpakov, "The molecular determinants in the serpentine type receptors, responsible for its functional coupling with the heterotrimeric G-protein," Tsitologiia, vol. 44, pp. 242-258, 2002 (Russian).

[24] F. Fanelli, P. G. De Benedetti, F. Raimondi, and M. Seeber, "Computational modeling of intramolecular and intermolecular communication in GPCRs," Current Protein and Peptide Science, vol. 10, no. 2, pp. 173-185, 2009.

[25] J. M. Taylor and R. R. Neubig, "Peptides as probes for G protein signal transduction," Cellular Signalling, vol. 6, no. 8, pp. 841-849, 1994.

[26] J. Miller, A. Agarwal, L. A. Devi et al., "Insider access: pepducin symposium explores a new approach to GPCR modulation," Annals of the New York Academy of Sciences, vol. 1180, no. 1, pp. E1-E12, 2009.

[27] S. L. Tressel, G. Koukos, B. Tchernychev, S. L. Jacques, L. Covic, and A. Kuliopulos, "Pharmacology, biodistribution, and efficacy of GPCR-based pepducins in disease models," Methods in Molecular Biology, vol. 683, pp. 259-275, 2011.

[28] W. J. Phillips and R. A. Cerione, "A C-terminal peptide of bovine rhodopsin binds to the transducin $\alpha$-subunit and facilitates its activation," Biochemical Journal, vol. 299, no. 2, pp. 351-357, 1994.

[29] P. L. Yeagle, J. L. Alderfer, and A. D. Albert, "Structure determination of the fourth cytoplasmic loop and carboxyl terminal domain in bovine rhodopsin," Molecular Vision, vol. 2, p. 12, 1996.

[30] T. Okamoto and I. Nishimoto, "Detection of G proteinactivator regions in M4 subtype muscarinic, cholinergic, and $\alpha_{2}$-adrenergic receptors based upon characteristics in primary structure," Journal of Biological Chemistry, vol. 267, no. 12, pp. 8342-8346, 1992.

[31] S. M. Wade, H. M. Dalman, S. Z. Yang, and R. R. Neubig, "Multisite interactions of receptors and $\mathrm{G}$ proteins: enhanced potency of dimeric receptor peptides in modifying $G$ protein function," Molecular Pharmacology, vol. 45, no. 6, pp. 11911197, 1994.

[32] C. A. Johnston and D. P. Siderovski, "Structural basis for nucleotide exchange on $\mathrm{G} \alpha \alpha_{i}$ subunits and receptor coupling specificity," Proceedings of the National Academy of Sciences of the United States of America, vol. 104, no. 6, pp. 2001-2006, 2007.

[33] D. Palm, G. Munch, C. Dees, and M. Hekman, "Mapping of $\beta$-adrenoceptor coupling domains to $\mathrm{G}_{s}$-protein by sitespecific synthetic peptides," Federation of the Societies of
Biochemistry and Molecular Biology Letters, vol. 254, no. 1-2, pp. 89-93, 1989.

[34] G. Munch, C. Dees, M. Hekman, and D. Palm, "Multisite contacts involved in coupling of the $\beta$-adrenergic receptor with the stimulatory guanine-nucleotide-binding regulatory protein: structural and functional studies by $\beta$-receptor-sitespecific synthetic peptides," European Journal of Biochemistry, vol. 198, no. 2, pp. 357-364, 1991.

[35] T. Okamoto, Y. Murayama, Y. Hayashi, M. Inagaki, E. Ogata, and I. Nishimoto, "Identification of a $\mathrm{G}_{s}$ activator region of the $\beta_{2}$-adrenergic receptor that is autoregulated via protein kinase A-dependent phosphorylation," Cell, vol. 67, no. 4, pp. 723-730, 1991.

[36] J. M. Taylor, G. G. Jacob-Mosier, R. G. Lawton, A. E. Remmers, and R. R. Neubig, "Binding of an $\alpha_{2}$ adrenergic receptor third intracellular loop peptide to $G \beta$ and the amino terminus of G $\alpha$," Journal of Biological Chemistry, vol. 269, no. 44, pp. 27618-27624, 1994.

[37] A. M. Cypess, C. G. Unson, C. R. Wu, and T. P. Sakmar, "Two cytoplasmic loops of the glucagon receptor are required to elevate cAMP of intracellular calcium," Journal of Biological Chemistry, vol. 274, no. 27, pp. 19455-19464, 1999.

[38] B. Konig and M. Gratzel, "Site of dopamine $D_{1}$ receptor binding to $\mathrm{G}_{s}$ protein mapped with synthetic peptides," Biochimica et Biophysica Acta, vol. 1223, no. 2, pp. 261-266, 1994.

[39] A. O. Shpakov, E. A. Shpakova, I. I. Tarasenko, K. V. Derkach, and G. P. Vlasov, "The peptides mimicking the third intracellular loop of 5-hydroxytryptamine receptors of the types $1 \mathrm{~B}$ and 6 selectively activate $\mathrm{G}$ proteins and receptor-specifically inhibit serotonin signaling via the adenylyl cyclase system," International Journal of Peptide Research and Therapeutics, vol. 16, no. 2, pp. 95-105, 2010.

[40] T. Voss, E. Wallner, A. P. Czernilofsky, and M. Freissmuth, "Amphipathic $\alpha$-helical structure does not predict the ability of receptor-derived synthetic peptides to interact with guanine nucleotide-binding regulatory proteins," Journal of Biological Chemistry, vol. 268, no. 7, pp. 4637-4642, 1993.

[41] Q. Q. Sun and N. Dale, "G-proteins are involved in 5-HT receptor-mediated modulation of $\mathrm{N}$ - and $\mathrm{P} / \mathrm{Q}$ - but not Ttype $\mathrm{Ca}^{2+}$ channels," Journal of Neuroscience, vol. 19, no. 3, pp. 890-899, 1999.

[42] C. Nanoff, R. Koppensteiner, Q. Yang, E. Fuerst, H. Ahorn, and M. Freissmuth, "The carboxyl terminus of the $\mathrm{G} \alpha$ subunit is the latch for triggered activation of heterotrimeric G proteins," Molecular Pharmacology, vol. 69, no. 1, pp. 397405, 2006.

[43] M. Kubota and K. Wakamatsu, "Peptide fragment of the m3 muscarinic acetylcholine receptor activates $\mathrm{G}_{q}$ but not $\mathrm{G}_{i 2}$," Journal of Peptide Science, vol. 14, no. 8, pp. 998-1002, 2008.

[44] A. O. Shpakov, I. I. Tarasenko, and E. A. Shpakova, "Peptides derived from the third cytoplasmic loop of type 6 serotonin receptor as regulators of serotonin-sensitive adenylyl cyclase signaling system," Doklady Biochemistry and Biophysics, vol. 431, no. 1, pp. 94-97, 2010.

[45] E. Morou and Z. Georgoussi, "Expression of the third intracellular loop of the $\delta$-opioid receptor inhibits signaling by opioid receptors and other G protein-coupled receptors," Journal of Pharmacology and Experimental Therapeutics, vol. 315, no. 3, pp. 1368-1379, 2005.

[46] P. Grasso, M. R. Deziel, and L. E. Reichert, "Selective effects of charge on G protein activation by $\mathrm{FSH}$-receptor residues 551-555 and 650-653," Peptide Research, vol. 8, no. 5, pp. 278-284, 1995. 
[47] P. Grasso, N. Leng, and L. E. Reichert, "A synthetic peptide corresponding to the third cytoplasmic loop (residues 533 to 555) of the testicular follicle-stimulating hormone receptor affects signal transduction in rat testis membranes and in intact cultured rat Sertoli cells," Molecular and Cellular Endocrinology, vol. 110, no. 1-2, pp. 35-41, 1995.

[48] S. Mukherjee, K. Palczewski, V. V. Gurevich, and M. Hunzicker-Dunn, " $\beta$-Arrestin-dependent desensitization of luteinizing hormone/choriogonadotropin receptor is prevented by a synthetic peptide corresponding to the third intracellular loop of the receptor," Journal of Biological Chemistry, vol. 274, no. 19, pp. 12984-12989, 1999.

[49] A. O. Shpakov, M.N. Pertseva, G. P. Gur'ianov, and I. A. Vlasov, "The influence of the peptides, derivatives of the third cytoplasmic loop of type 1 relaxin receptor, on the stimulation of GTP binding activity of the G proteins by relaxin," Journal of Membrane Biology, vol. 22, pp. 435-442, 2005 (Russian).

[50] A. O. Shpakov, I. A. Gur'yanov, L. A. Kuznetsova et al., "Studies of the molecular mechanisms of action of relaxin on the adenylyl cyclase signaling system using synthetic peptides derived from the LGR7 relaxin receptor," Neuroscience and Behavioral Physiology, vol. 37, no. 7, pp. 705-714, 2007.

[51] A. O. Shpakov, I. A. Gur'yanov, I. I. Tarasenko, and G. P. Vlasov, "Effects of polycationic peptides of different natures on the functional state of the serotonin-regulated adenylate cyclase system in the rat brain," Journal of Neurochemistry, vol. 3, pp. 272-281, 2009.

[52] J. Plati, N. Tsomaia, A. Piserchio, and D. F. Mierke, "Structural features of parathyroid hormone receptor coupled to G $\alpha_{s}$-protein," Biophysical Journal, vol. 92, no. 2, pp. 535-540, 2007.

[53] A. Bavec, M. Hällbrink, U. Langel, and M. Zorko, "Different role of intracellular loops of glucagon-like peptide-1 receptor in G-protein coupling," Regulatory Peptides, vol. 111, no. 1-3, pp. 137-144, 2003.

[54] S. M. Wade, M. K. Scribner, H. M. Dalman, J. M. Taylor, and R. R. Neubig, "Structural requirements for $\mathrm{G}_{o}$ activation by receptor-derived peptides: activation and modulation domains of the $\alpha_{2}$-adrenergic receptor i3c region," Molecular Pharmacology, vol. 50, no. 2, pp. 351-358, 1996.

[55] S. Granier, S. Terrillon, R. Pascal et al., "A cyclic peptide mimicking the third intracellular loop of the $V_{2}$ vasopressin receptor inhibits signaling through its interaction with receptor dimer and G protein," Journal of Biological Chemistry, vol. 279, no. 49, pp. 50904-50914, 2004.

[56] A. C. Howlett, C. Song, B. A. Berglund, G. H. Wilken, and J. J. Pigg, "Characterization of $\mathrm{CB}_{1}$ cannabinoid receptors using receptor peptide fragments and site-directed antibodies," Molecular Pharmacology, vol. 53, no. 3, pp. 504-510, 1998.

[57] S. Mukhopadhyay and A. C. Howlett, " $\mathrm{CB}_{1}$ receptor-G protein association: subtype selectivity is determined by distinct intracellular domains," European Journal of Biochemistry, vol. 268, no. 3, pp. 499-505, 2001.

[58] A. L. Ulfers, J. L. McMurry, A. Miller, L. Wang, D. A. Kendall, and D. F. Mierke, "Cannabinoid receptor-G protein interactions: $\mathrm{G}_{\alpha i 1}$-bound structures of IC3 and a mutant with altered G protein specificity," Protein Science, vol. 11, no. 10, pp. 2526-2531, 2002.

[59] H. Shirai, K. Takahashi, T. Katada, and T. Inagami, "Mapping of $\mathrm{G}$ protein coupling sites of the angiotensin II type 1 receptor," Hypertension, vol. 25, no. 4, pp. 726-730, 1995.

[60] T. Sano, K. Ohyama, Y. Yamano et al., "A domain for G protein coupling in carboxyl-terminal tail of rat angiotensin
II receptor type 1A," Journal of Biological Chemistry, vol. 272, no. 38, pp. 23631-23636, 1997.

[61] H. Kai, R. W. Alexander, M. Ushio-Fukai, P. R. Lyons, M. Akers, and K. K. Griendling, "G-protein binding domains of the angiotensin $\mathrm{II}_{\mathrm{AT}} \mathrm{T}_{1 A}$ receptors mapped with synthetic peptides selected from the receptor sequence," Biochemical Journal, vol. 332, no. 3, pp. 781-787, 1998.

[62] L. Franzoni, G. Nicastro, T. A. Pertinhez et al., "Structure of the C-terminal fragment 300-320 of the rat angiotensin II $\mathrm{AT}_{1 A}$ receptor and its relevance with respect to G-protein coupling," Journal of Biological Chemistry, vol. 272, no. 15, pp. 9734-9741, 1997.

[63] R. E. Schreiber, E. R. Prossnitz, R. D. Ye, C. G. Cochrane, and G. M. Bokoch, "Domains of the human neutrophil N-formyl peptide receptor involved in G protein coupling: mapping with receptor-derived peptides," Journal of Biological Chemistry, vol. 269, no. 1, pp. 326-331, 1994.

[64] R. K. Bommakanti, E. A. Dratz, D. W. Siemsen, and A. J. Jesaitis, "Extensive contact between $\mathrm{G}_{i 2}$ and $\mathrm{N}$-formyl peptide receptor of human neutrophils: mapping of binding sites using receptor-mimetic peptides," Biochemistry, vol. 34, pp. 6720-6728, 1995.

[65] L. Zhang, G. Huang, J. Wu, and K. H. Ruan, "A profile of the residues in the first intracellular loop critical for $\mathrm{G}_{s}$ mediated signaling of human prostacyclin receptor characterized by an integrative approach of NMR-experiment and mutagenesis," Biochemistry, vol. 44, no. 34, pp. 11389-11401, 2005.

[66] L. Zhang, J. Wu, and K. H. Ruan, "Solution structure of the first intracellular loop of prostacyclin receptor and implication of its interaction with the C-terminal segment of $\mathrm{G} \alpha$ s protein," Biochemistry, vol. 45, no. 6, pp. 1734-1744, 2006.

[67] H. K. Kole, M. J. Garant, S. Kole, and M. Bernier, "A peptidebased protein-tyrosine phosphatase inhibitor specifically enhances insulin receptor function in intact cells," Journal of Biological Chemistry, vol. 271, no. 24, pp. 14302-14307, 1996.

[68] H. K. Kole, A. S. Liotta, S. Kole, J. Roth, C. MontroseRafizadeh, and M. Bernier, "A synthetic peptides derived from a $\mathrm{COOH}$-terminal domain of the insulin receptor specifically enhances insulin receptor signaling," Journal of Biological Chemistry, vol. 271, no. 49, pp. 31619-31626, 1996.

[69] H. Sun, J. M. Seyer, and T. B. Patel, "A region in the cytosolic domain of the epidermal growth factor receptor antithetically regulates the stimulatory and inhibitory guanine nucleotidebinding regulatory proteins of adenylyl cyclase," Proceedings of the National Academy of Sciences of the United States of America, vol. 92, no. 6, pp. 2229-2233, 1995.

[70] M. Pagano and M. B. Anand-Srivastava, "Cytoplasmic domain of natriuretic peptide receptor C constitutes $\mathrm{G}_{i}$ activator sequences that inhibit adenylyl cyclase activity," Journal of Biological Chemistry, vol. 276, no. 25, pp. 2206422070, 2001.

[71] H. Zhou and K. S. Murthy, "Identification of the G proteinactivating sequence of the single-transmembrane natriuretic peptide receptor C (NPR-C)," American Journal of Physiology, vol. 284, no. 5, pp. 1255-1261, 2003.

[72] S. Hashim, Y. Li, and M. B. Anand-Srivastava, "Small cytoplasmic domain peptides of natriuretic peptide receptor$\mathrm{C}$ attenuate cell proliferation through $\mathrm{G}_{i} \alpha$ protein/MAP kinase/PI3-kinase/AKT pathways," American Journal of Physiology, vol. 291, no. 6, pp. 3144-3153, 2006.

[73] H. E. Hamm, D. Deretic, A. Arendt, P. A. Hargrave, B. Koenig, and K. P. Hofmann, "Site of G protein binding to rhodopsin 
mapped with synthetic peptides from the $\alpha$ subunit," Science, vol. 241, no. 4867, pp. 832-835, 1988.

[74] T. Morizumi, H. Imai, and Y. Shichida, "Two-step mechanism of interaction of rhodopsin intermediates with the C-terminal region of the transducin $\alpha$-subunit," Journal of Biochemistry, vol. 134, no. 2, pp. 259-267, 2003.

[75] T. E. Angel, P. C. Kraft, and E. A. Dratz, "MetarhodopsinII stabilization by crosslinked $\mathrm{Gt}_{\alpha} \mathrm{C}$-terminal peptides and implications for the mechanism of GPCR-G protein coupling," Vision Research, vol. 46, no. 27, pp. 4547-4555, 2006.

[76] P. Scheerer, J. H. Park, P. W. Hildebrand et al., "Crystal structure of opsin in its G-protein-interacting conformation," Nature, vol. 455, no. 7212, pp. 497-502, 2008.

[77] M. R. Mazzoni, S. Taddei, L. Giusti et al., "A G $\alpha_{s}$ carboxylterminal peptide prevents $\mathrm{G}_{s}$ activation by the $\mathrm{A}_{2 A}$ adenosine receptor," Molecular Pharmacology, vol. 58, no. 1, pp. 226236, 2000.

[78] Y. Chen, B. Yoo, J. B. Lee, G. Weng, and R. Iyengar, "The signal transfer regions of $\mathrm{G}_{\alpha s}$," Journal of Biological Chemistry, vol. 276, no. 49, pp. 45751-45754, 2001.

[79] T. Vorherr, L. Knöpfel, F. Hofmann, S. Mollner, T. Pfeuffer, and E. Carafoli, "The calmodulin binding domain of nitric oxide synthase and adenylyl cyclase," Biochemistry, vol. 32, no. 23, pp. 6081-6088, 1993.

[80] S. Diel, M. Beyermann, J. M. N. Lloréns, B. Wittig, and C. Kleuss, "Two interaction sites on mammalian adenylyl cyclase type I and II: modulation by calmodulin and $\mathrm{G}_{\beta \gamma}$," Biochemical Journal, vol. 411, no. 2, pp. 449-456, 2008.

[81] B. Yoo, R. Iyengar, and Y. Chen, "Functional analysis of the interface regions involved in interactions between the central cytoplasmic loop and the C-terminal tail of adenylyl cyclase," Journal of Biological Chemistry, vol. 279, no. 14, pp. 1392513933, 2004.

[82] D. R. Grubb, O. Vasilevski, H. Huynh, and E. A. Woodcock, "The extreme C-terminal region of phospholipase $\mathrm{C} \beta 1$ determines subcellular localization and function; the " $\mathrm{b}$ " splice variant mediates $\alpha_{1}$-adrenergic receptor responses in cardiomyocytes," Federation of American Societies for Experimental Biology Journal, vol. 22, no. 8, pp. 2768-2774, 2008.

[83] T. M. Filtz, D. R. Grubb, T. J. McLeod-Dryden, J. Luo, and E. A. Woodcock, "G $\mathrm{G}_{q}$-initiated cardiomyocyte hypertrophy is mediated by phospholipase $\mathrm{C} \beta 1 \mathrm{~b}$," Federation of American Societies for Experimental Biology Journal, vol. 23, no. 10, pp. 3564-3570, 2009.

[84] J. I. Hwang, H. S. Kim, J. R. Lee, E. Kim, S. H. Ryu, and P. G. Suh, "The interaction of phospholipase C- $\beta 3$ with Shank2 regulates mGluR-mediated calcium signal," Journal of Biological Chemistry, vol. 280, no. 13, pp. 12467-12473, 2005.

[85] M. K. Komma, M. Yamasaki, S. Ohmi, and Y. Homma, "Inhibition of phosphoinositide hydrolysis and cell growth of Swiss 3T3 cells by myristoylated phospholipase C inhibitor peptides," Journal of Biochemistry, vol. 122, no. 4, pp. 738742, 1997.

[86] R. S. Sidhu, R. R. Clough, and R. P. Bhullar, "Regulation of phospholipase C- $\delta 1$ through direct interactions with the small GTPase Ral and calmodulin," Journal of Biological Chemistry, vol. 280, no. 23, pp. 21933-21941, 2005.

[87] T. H. Lai, Y. F. Lin, F. C. Wu, and Y. H. Tsai, "Folliclestimulating hormone-induced $\mathrm{G} \alpha_{h} /$ phospholipase C- $\delta 1$ signaling mediating a noncapacitative $\mathrm{Ca}^{2+}$ influx through $\mathrm{T}$ type $\mathrm{Ca}^{+2}$ channels in rat sertoli cells," Endocrinology, vol. 149, no. 3, pp. 1031-1037, 2008.
[88] T. T. Ching, H. P. Lin, C. C. Yang, M. Oliveira, P. J. Lu, and C. S. Chen, "Specific binding of the C-terminal Src homology 2 domain of the p $85 \alpha$ subunit of phosphoinositide 3-kinase to phosphatidylinositol 3,4,5-trisphosphate: localization and engineering of the phosphoinositide-binding motif," Journal of Biological Chemistry, vol. 276, no. 47, pp. 43932-43938, 2001.

[89] K. Krotova, H. Hu, S. L. Xia et al., "Peptides modified by myristoylation activate eNOS in endothelial cells through Akt phosphorylation," British Journal of Pharmacology, vol. 148, no. 5, pp. 732-740, 2006.

[90] N. H. Lee, N. S. M. Geoghagen, E. Cheng, R. T. Cline, and C. M. Fraser, "Alanine scanning mutagenesis of conserved arginine/lysine-arginine/lysine-XX-arginine/lysine G protein-activating motifs on $\mathrm{m} 1$ muscarinic acetylcholine receptors," Molecular Pharmacology, vol. 50, no. 1, pp. 140148, 1996.

[91] A. O. Shpakov, "Involvement of charged amino acid residues of cytoplasmic loops of serpentine type receptors in the process of hormone signal transduction," Zhurnal Evoliutsionnoi Biokhimii i Fiziologii, vol. 39, no. 3, pp. 205-217, 2003.

[92] B. R. Conklin, Z. Farfel, K. D. Lustig, D. Julius, and H. R. Bourne, "Substitution of three amino acids switches receptor specificity of $\mathrm{G}_{q} \alpha$ to that of $\mathrm{G}_{i} \alpha$," Nature, vol. 363 , no. 6426 , pp. 274-276, 1993.

[93] D. G. Lambright, J. Sondek, A. Bohm, N. P. Skiba, H. E. Hamm, and P. B. Sigler, "The 2.0 A crystal structure of a heterotrimeric G protein,” Nature, vol. 379, no. 6563, pp. 311-319, 1996.

[94] J. E. Slessareva, H. Ma, K. M. Depree et al., "Closely related Gprotein-coupled receptors use multiple and distinct domains on G-protein $\alpha$ subunits for selective coupling," Journal of Biological Chemistry, vol. 278, no. 50, pp. 50530-50536, 2003.

[95] H. Bae, T. M. Cabrera-Vera, K. M. Depree, S. G. Graber, and H. E. Hamm, "Two amino acids within the helix of $\mathrm{G} \alpha_{i 1}$ mediate coupling with 5- hydroxytryptamine ${ }_{1 B}$ receptors," Journal of Biological Chemistry, vol. 274, no. 21, pp. 1496314971, 1999.

[96] T. Muramatsu and M. Suwa, "Statistical analysis and prediction of functional residues effective for GPCR-G-protein coupling selectivity," Protein Engineering, Design and Selection, vol. 19, no. 6, pp. 277-283, 2006.

[97] L. Covic, A. L. Gresser, J. Talavera, S. Swift, and A. Kuliopulos, "Activation and inhibition of $\mathrm{G}$ protein-coupled receptors by cell-penetrating membrane-tethered peptides," Proceedings of the National Academy of Sciences of the United States of America, vol. 99, no. 2, pp. 643-648, 2002.

[98] L. Covic, M. Misra, J. Badar, C. Singh, and A. Kuliopulos, "Pepducin-based intervention of thrombin-receptor signaling and systemic platelet activation," Nature Medicine, vol. 8, no. 10, pp. 1161-1165, 2002.

[99] T. Light, L. Tsirulnikov, H. Reuveni, T. Yarnitzky, and S. A. Ben-Sasson, "Induction of pro-angiogenic signaling by a synthetic peptide derived from the second intracellular loop of S1P3 (EDG3)," Blood, vol. 102, no. 6, pp. 2099-2107, 2003.

[100] N. C. Kaneider, A. Agarwal, A. J. Leger, and A. Kuliopulos, "Reversing systemic inflammatory response syndrome with chemokine receptor pepducins," Nature Medicine, vol. 11, no. 6, pp. 661-665, 2005.

[101] S. Swift, A. J. Leger, J. Talavera, L. Zhang, A. Bohm, and A. Kuliopulos, "Role of the PAR1 receptor $8^{\text {th }}$ helix in signaling: the 7-8-1 receptor activation mechanism," Journal of Biological Chemistry, vol. 281, no. 7, pp. 4109-4116, 2006. 
[102] R. J. Edwards, N. Moran, M. Devocelle et al., "Bioinformatic discovery of novel bioactive peptides," Nature Chemical Biology, vol. 3, no. 2, pp. 108-112, 2007.

[103] M. Majumdar, T. Tarui, B. Shi, N. Akakura, W. Ruf, and Y. Takada, "Plasmin-induced migration requires signaling through protease-activated receptor 1 and integrin $\alpha_{9} \beta_{1}$," Journal of Biological Chemistry, vol. 279, no. 36, pp. 3752837534, 2004.

[104] A. Boire, L. Covic, A. Agarwal, S. Jacques, S. Sherifi, and A. Kuliopulos, "PAR1 is a matrix metalloprotease-1 receptor that promotes invasion and tumorigenesis of breast cancer cells," Cell, vol. 120, no. 3, pp. 303-313, 2005.

[105] N. C. Kaneider, A. J. Leger, A. Agarwal et al., "'Role reversal' for the receptor PAR1 in sepsis-induced vascular damage," Nature Immunology, vol. 8, no. 12, pp. 1303-1312, 2007.

[106] A. J. Leger, S. L. Jacques, J. Badar et al., "Blocking the protease-activated receptor 1-4 heterodimer in plateletmediated thrombosis," Circulation, vol. 113, no. 9, pp. 12441254, 2006.

[107] J. R. Remsberg, H. Lou, S. G. Tarasov, M. Dean, and N. I. Tarasova, "Structural analogues of smoothened intracellular loops as potent inhibitors of Hedgehog pathway and cancer cell growth," Journal of Medicinal Chemistry, vol. 50, no. 18, pp. 4534-4538, 2007.

[108] A. Agarwal, L. Covic, L. M. Sevigny et al., "Targeting a metalloprotease-PAR1 signaling system with cell-penetrating pepducins inhibits angiogenesis, ascites, and progression of ovarian cancer," Molecular Cancer Therapeutics, vol. 7, no. 9, pp. 2746-2757, 2008.

[109] V. Trivedi, A. Boire, B. Tchernychev et al., "Platelet matrix metalloprotease-1 mediates thrombogenesis by activating PAR1 at a cryptic ligand site," Cell, vol. 137, no. 2, pp. 332343, 2009.

[110] M. D. Hollenberg, M. Saifeddine, S. Sandhu, S. Houle, and N. Vergnolle, "Proteinase-activated receptor-4: evaluation of tethered ligand-derived peptides as probes for receptor function and as inflammatory agonists in vivo," British Journal of Pharmacology, vol. 143, no. 4, pp. 443-454, 2004.

[111] S. H. Slofstra, M. F. Bijlsma, A. P. Groot et al., "Proteaseactivated receptor 4 inhibition protects from multiorgan failure in a murine model of systemic inflammation," Blood, vol. 110, no. 9, pp. 3176-3182, 2007.

[112] S. Kubo, T. Ishiki, I. Doe et al., "Distinct activity of peptide mimetic intracellular ligands (pepducins) for proteinaseactivated receptor-1 in multiple cells/tissues," Annals of the New York Academy of Sciences, vol. 1091, pp. 445-459, 2006.

[113] C. K. Derian, B. P. Damiano, M. F. Addo et al., "Blockade of the thrombin receptor protease-activated receptor-1 with a small-molecule antagonist prevents thrombus formation and vascular occlusion in nonhuman primates," Journal of Pharmacology and Experimental Therapeutics, vol. 304, no. 2, pp. 855-861, 2003.

[114] S. S. Smyth, D. S. Woulfe, J. I. Weitz et al., "G-protein-coupled receptors as signaling targets for antiplatelet therapy," Arteriosclerosis, Thrombosis, and Vascular Biology, vol. 29, pp. 449-457, 2009.

[115] S. J. Wielders, A. Bennaghmouch, C. P. Reutelingsperger, E. M. Bevers, and T. Lindhout, "Anticoagulant and antithrombotic properties of intracellular protease-activated receptor antagonists," Journal of Thrombosis and Haemostasis, vol. 5, pp. 571-576, 2007.

[116] J. Kreuzer, B. Nürnberg, and H. I. Krieger-Brauer, "Liganddependent autophosphorylation of the insulin receptor is positively regulated by $\mathrm{G}_{i}$-proteins," Biochemical Journal, vol. 380, no. 3, pp. 831-836, 2004.

[117] T. Okamoto, T. Okamoto, Y. Murayama, Y. Hayashi, E. Ogata, and I. Nishimoto, "GTP-binding protein-activator sequences in the insulin receptor," Federation of the Societies of Biochemistry and Molecular Biology Letters, vol. 334, no. 1, pp. 143-148, 1993.

[118] H. Jo, W. Radding, G. M. Anantharamaiah, and J. M. McDonald, "An insulin receptor peptide (1135-1156) stimulates guanosine 5 '-[ $\gamma$-thio $]$ triphosphate binding to the $67 \mathrm{kDa}$ G-protein associated with the insulin receptor," Biochemical Journal, vol. 294, no. 1, pp. 19-24, 1993.

[119] S. A. Plesneva, A. O. Shpakov, L. A. Kuznetsova, and M. N. Pertseva, "A dual role of protein kinase $\mathrm{C}$ in insulin signal transduction via adenylyl cyclase signaling system in muscle tissues of vertebrates and invertebrates," Biochemical Pharmacology, vol. 61, no. 10, pp. 1277-1291, 2001.

[120] A. S. Liotta, H. K. Kole, H. M. Fales, J. Roth, and M. Bernier, "A synthetic tris-sulfotyrosyl dodecapeptide analogue of the insulin receptor 1146-kinase domain inhibits tyrosine dephosphorylation of the insulin receptor in situ," Journal of Biological Chemistry, vol. 269, no. 37, pp. 22996-23001, 1994.

[121] M. Bernier, H. K. Kole, C. Montrose-Rafizadeh, and S. Kole, "Discrete region of the insulin receptor carboxyl terminus plays key role in insulin action," Journal of Cellular Biochemistry, vol. 78, no. 1, pp. 160-169, 2000.

[122] P. Kaliman, V. Baron, F. Alengrin et al., "The insulin receptor $\mathrm{C}$-terminus is involved in regulation of the receptor kinase activity," Biochemistry, vol. 32, pp. 9539-9544, 1993.

[123] V. Baron, P. Kaliman, F. Alengrin, and E. Van Obberghen, "Interaction of the C-terminal acidic domain of the insulin receptor with histone modulates the receptor kinase activity," European Journal of Biochemistry, vol. 229, no. 1, pp. 27-34, 1995.

[124] P. Gual, V. Baron, F. Alengrin, I. Mothe, and E. Van Obberghen, "Insulin receptor-induced phosphorylation of cellular and synthetic substrates is regulated by the receptor $\beta$-subunit C-terminus," Endocrinology, vol. 137, no. 8, pp. 3416-3423, 1996.

[125] C. S. Lee, K. L. Kim, J. H. Jang, Y. S. Choi, P. G. Suh, and S. H. Ryu, "The roles of phospholipase D in EGFR signaling," Biochimica et Biophysica Acta, vol. 1791, pp. 862-868, 2009.

[126] D. N. Dhanasekaran, "Transducing the signals: a G protein takes a new identity," Science's: Signal Transduction Knowledge Environment, vol. 2006, no. 347, p. pe31, 2006.

[127] C. Cao, X. Huang, Y. Han et al., " $\mathrm{G} \alpha_{i 1}$ and $\mathrm{G} \alpha_{i 3}$ are required for epidermal growth factor-mediated activation of the AktmTORC1 pathway," Science Signaling, vol. 2, no. 68, p. ra17, 2009.

[128] W. X. Schulze and M. Mann, "A novel proteomic screen for peptide-protein interactions," Journal of Biological Chemistry, vol. 279, no. 11, pp. 10756-10764, 2004.

[129] W. X. Schulze, L. Deng, and M. Mann, "Phosphotyrosine interactome of the ErbB-receptor kinase family," Molecular Systems Biology, vol. 1, p. 2005.0008, 2005.

[130] R. Mouawad, Y. Li, and M. B. Anand-Srivastava, "Atrial natriuretic peptide- $\mathrm{C}$ receptor-induced attenuation of adenylyl cyclase signaling activates phosphatidylinositol turnover in A10 vascular smooth muscle cells," Molecular Pharmacology, vol. 65, no. 4, pp. 917-924, 2004.

[131] M. B. Anand-Srivastava, P. D. Sehl, and D. G. Lowe, "Cytoplasmic domain of natriuretic peptide receptor-C inhibits adenylyl cyclase. Involvement of a pertussis toxin-sensitive $\mathrm{G}$ 
protein," Journal of Biological Chemistry, vol. 271, no. 32, pp. 19324-19329, 1996.

[132] K. S. Murthy and G. M. Makhlouf, "Identification of the $\mathrm{G}$ protein-activating domain of the natriuretic peptide clearance receptor (NPR-C)," Journal of Biological Chemistry, vol. 274, no. 25, pp. 17587-17592, 1999.

[133] T. Okamoto, T. Katada, Y. Murayama, M. Ui, E. Ogata, and I. Nishimoto, "A simple structure encodes G protein-activating function of the IGF-II/mannose 6-phosphate receptor," Cell, vol. 62, no. 4, pp. 709-717, 1990.

[134] S. Offermanns, "G-proteins as transducers in transmembrane signalling," Progress in Biophysics and Molecular Biology, vol. 83, no. 2, pp. 101-130, 2003.

[135] N. Van Eps, L. L. Anderson, O. G. Kisselev, T. J. Baranski, W. L. Hubbell, and G. R. Marshall, "Electron paramagnetic resonance studies of functionally active, nitroxide spinlabeled peptide analogues of the C-terminus of a G-protein $\alpha$ subunit," Biochemistry, vol. 49, no. 32, pp. 6877-6886, 2010.

[136] K. P. Hofmann, "Signalling states of photoactivated rhodopsin," Novartis Foundation Symposium, vol. 224, pp. 158-175, 1999.

[137] S. Acharya, Y. Saad, and S. S. Karnik, "Transducin- $\alpha$ Cterminal peptide binding site consists of C-D and E-F loops of rhodopsin," Journal of Biological Chemistry, vol. 272, no. 10, pp. 6519-6524, 1997.

[138] O. G. Kisselev, J. Kao, J. W. Ponder, Y. C. Fann, N. Gautam, and G. R. Marshall, "Light-activated rhodopsin induces structural binding motif in $\mathrm{G}$ protein $\alpha$ subunit," Proceedings of the National Academy of Sciences of the United States of America, vol. 95, no. 8, pp. 4270-4275, 1998.

[139] B. W. Koenig, G. Kontaxis, D. C. Mitchell, J. M. Louis, B. J. Litman, and A. Bax, "Structure and orientation of a G protein fragment in the receptor bound state from residual dipolar couplings," Journal of Molecular Biology, vol. 322, no. 2, pp. 441-461, 2002.

[140] K. Fahmy, "Binding of transducin and transducin-derived peptides to rhodopsin studies by attenuated total reflectionFourier transform infrared difference spectroscopy," Biophysical Journal, vol. 75, no. 3, pp. 1306-1318, 1998.

[141] L. Aris, A. Gilchrist, S. Rens-Domiano et al., "Structural requirements for the stabilization of metarhodopsin II by the C terminus of the $\alpha$ subunit of transducin," Journal of Biological Chemistry, vol. 276, no. 4, pp. 2333-2339, 2001.

[142] E. L. Martin, S. Rens-Domiano, P. J. Schatz, and H. E. Hamm, "Potent peptide analogues of a G protein receptor-binding region obtained with a combinatorial library," Journal of Biological Chemistry, vol. 271, no. 1, pp. 361-366, 1996.

[143] M. M. Rasenick, M. Watanabe, M. B. Lazarevic, S. Hatta, and H. E. Hamm, "Synthetic peptides as probes for G protein function. Carboxyl-terminal $\mathrm{G} \alpha$ s peptides mimic $\mathrm{G}_{2}$ and evoke high affinity agonist binding to $\beta$-adrenergic receptors," Journal of Biological Chemistry, vol. 269, no. 34, pp. 21519-21525, 1994.

[144] J. Novotny, B. Gustafson, and L. A. Ransnas, "Inhibition of $\beta$ adrenergic receptor-mediated signals by a synthetic peptide derived from the $\alpha$ subunit of the stimulatory G-protein," Biochemical and Biophysical Research Communications, vol. 219, pp. 619-624, 1996.

[145] M. Chang, L. Zhang, J. P. Tam, and E. Sanders-Bush, "Dissecting G protein-coupled receptor signaling pathways with membrane-permeable blocking peptides. Endogenous $5-\mathrm{HT}_{2 \mathrm{C}}$ receptors in choroid plexus epithelial cells," Journal of Biological Chemistry, vol. 275, no. 10, pp. 7021-7029, 2000.
[146] D. S. Feldman, A. M. Zamah, K. L. Pierce et al., "Selective inhibition of heterotrimeric $\mathrm{G}_{s}$ signaling. Targeting the receptor- $\mathrm{G}$ protein interface using a peptide minigene encoding the $\mathrm{G} \alpha_{s}$ carboxyl terminus," Journal of Biological Chemistry, vol. 277, no. 32, pp. 28631-28640, 2002.

[147] P. Grieco, S. Albrizio, A. M. D’Ursi et al., “A structure-activity relationship study on position-2 of the $\mathrm{G} \alpha_{s}$ C-terminal peptide able to inhibit $G_{s}$ activation by $A_{2 A}$ adenosine receptor," European Journal of Medicinal Chemistry, vol. 38, no. 1, pp. 13-18, 2003.

[148] A. O. Shpakov, I. A. Gur'ianov, L. A. Kuznetsova et al., "The using of C-terminal peptides of G protein $\alpha$-subunits for the study of their functional coupling with receptors of biogenic amines in rat and mollusk tissues," Journal of Membrane Biology, vol. 21, pp. 441-450, 2004 (Russian).

[149] A. O. Shpakov, V. I. Korolkov, S. A. Plesneva, L. A. Kuznetsova, and M. N. Pertseva, "Effects of the C-terminal peptide of the $\alpha_{s}$ subunit of the G protein on the regulation of adenylyl cyclase and protein kinase A activities by biogenic amines and glucagon in mollusk and rat muscles," Neuroscience and Behavioral Physiology, vol. 35, pp. 177-186, 2005.

[150] A. O. Shpakov, V. N. Shipilov, and V. M. Bondareva, "Sensitivity of adenylyl cyclase signaling system of the mollusk A. cygnea ganglions to serotonin and adrenergic agonists," Annals of the New York Academy of Sciences, vol. 1040, pp. 466-468, 2005.

[151] A. M. D’Ursi, L. Giusti, S. Albrizio et al., "A membranepermeable peptide containing the last 21 residues of the $\mathrm{G} \alpha_{s}$ carboxyl terminus inhibits $\mathrm{G}_{s}$-coupled receptor signaling in intact cells: correlations between peptide structure and biological activity," Molecular Pharmacology, vol. 69, no. 3, pp. 727-736, 2006.

[152] R. K. Sunahara, J. J. G. Tesmer, A. G. Gilman, and S. R. Sprang, "Crystal structure of the adenylyl cyclase activator $\mathrm{G}_{s \alpha}$," Science, vol. 278, no. 5345, pp. 1943-1947, 1997.

[153] S. Albrizio, A. D’Ursi, C. Fattorusso et al., "Conformational studies on a synthetic C-terminal fragment of the $\alpha$ subunit of $\mathrm{G}_{s}$ proteins," Biopolymers, vol. 54, no. 3, pp. 186-194, 2000.

[154] A. Gilchrist, M. Bünemann, A. Li, M. M. Hosey, and H. E. Hamm, "A dominant-negative strategy for studying roles of G proteins in vivo," Journal of Biological Chemistry, vol. 274, no. 10, pp. 6610-6616, 1999.

[155] A. Gilchrist, J. F. Vanhauwe, A. Li, T. O. Thomas, T. VoynoYasenetskaya, and H. E. Hamm, " $\mathrm{G} \alpha$ minigenes expressing C-terminal peptides serves as specific inhibitors of thrombinmediated endothelial activation," Journal of Biological Chemistry, vol. 276, no. 28, pp. 25672-25679, 2001.

[156] J. F. Vanhauwe, T. O. Thomas, R. D. Minshall et al., "Thrombin receptors activate $\mathrm{G}_{o}$ proteins in endothelial cells to regulate intracellular calcium and cell shape changes," Journal of Biological Chemistry, vol. 277, no. 37, pp. 3414334149, 2002.

[157] A. Chillar, J. Wu, V. Cervantes, and K. H. Ruan, "Structural and functional analysis of the C-terminus of $\mathrm{G} \alpha$ in complex with the human thromboxane A2 receptor provides evidence of constitutive activity," Biochemistry, vol. 49, no. 30, pp. 6365-6374, 2010.

[158] A. O. Shpakov, I. A. Gur'ianov, E. V. Avdeeva, V. I. Vorob’ev, and G. P. Vlasov, "Molecular mechanisms of action of dendrons, containing 48-60 sequence of HIV-1 TAT-protein, on the functional activity of the adenylyl cyclase signaling systems," Tsitologiia, vol. 46, no. 11, pp. 1011-1022, 2004 (Russian). 
[159] A. O. Shpakov, I. A. Gur'ianov, G. P. Vlasov, and M. N. Pertseva, "The molecular mechanisms of the interaction of polycationic peptides with the serpentine type receptors and the heterotrimeric G proteins in rat tissues," Journal of Evolutionary Biochemistry and Physiology, vol. 42, pp. 321327, 2006.

[160] A. O. Shpakov, I. A. Gur'yanov, N. V. Bayanova, and G. P. Vlasov, "Receptor of the serpentine type and heterotrimeric G protein as targets of action of polylysine dendrimers," Cell and Tissue Biology, vol. 3, no. 1, pp. 14-22, 2009.

[161] G. Grishina and C. H. Berlot, "Identification of common and distinct residues involved in the interaction of $\alpha_{i 2}$ and $\alpha_{s}$ with adenylyl cyclase," Journal of Biological Chemistry, vol. 272, no. 33, pp. 20619-20626, 1997.

[162] M. J. Rebecchi and S. N. Pentyala, "Structure, function, and control of phosphoinositide-specific phospholipase C," Physiological Reviews, vol. 80, no. 4, pp. 1291-1335, 2000.

[163] I. Litosch, "Novel mechanisms for feedback regulation of phospholipase C- $\beta$ activity," International Union of Biochemistry and Molecular Biology Life, vol. 54, no. 5, pp. 253-260, 2002.

[164] S. A. Akhter, L. M. Luttrell, H. A. Rockman, G. Iaccarino, R. J. Lefkowitz, and W. J. Koch, "Targeting the receptor$\mathrm{G}_{q}$ interface to inhibit in vivo pressure overload myocardial hypertrophy," Science, vol. 280, no. 5363, pp. 574-577, 1998.

[165] N. Wettschureck, H. Rütten, A. Zywietz et al., "Absence of pressure overload induced myocardial hypertrophy after conditional inactivation of $\mathrm{G} \alpha_{q} / \mathrm{G} \alpha_{11}$ in cardiomyocytes," Nature Medicine, vol. 7, no. 11, pp. 1236-1240, 2001.

[166] B. Sankaran, J. Osterhout, D. Wu, and A. V. Smrcka, "Identification of a structural element in phospholipase C $\beta 2$ that interacts with $\mathrm{G}$ protein $\beta \gamma$," Journal of Biological Chemistry, vol. 273, no. 12, pp. 7148-7154, 1998.

[167] Y. F. Lin, M. J. Tseng, H. L. Hsu, Y. W. Wu, Y. H. Lee, and Y. H. Tsai, "A novel follicle-stimulating hormone-induced $\mathrm{G} \alpha_{h} /$ phospholipase C- $\delta 1$ signaling pathway mediating rat Sertoli cell $\mathrm{Ca}^{2+}$-influx," Molecular Endocrinology, vol. 20, no. 10, pp. 2514-2527, 2006.

[168] R. L. Patterson, D. B. van Rossum, N. Nikolaidis, D. L. Gill, and S. H. Snyder, "Phospholipase C- $\gamma$ : diverse roles in receptor-mediated calcium signaling," Trends in Biochemical Sciences, vol. 30, no. 12, pp. 688-697, 2005.

[169] Y. Homma and T. Takenawa, "Inhibitory effect of src homology (SH) 2/SH3 fragments of phospholipase C- $\gamma$ on the catalytic activity of phospholipase C isoforms," Journal of Biological Chemistry, vol. 267, no. 30, pp. 21844-21849, 1992.

[170] Y. Homma, "Suppression of membrane phospholipase C activity by synthetic autoinhibitor peptides," Methods: Companion to Methods in Enzymology, vol. 5, pp. 229-232, 1993.

[171] P. T. Hawkins, K. E. Anderson, K. Davidson, and L. R. Stephens, "Signalling through Class I PI3Ks in mammalian cells," Biochemical Society Transactions, vol. 34, no. 5, pp. 647-662, 2006.

[172] A. C. Newton, "Protein kinase C: structural and spatial regulation by phosphorylation, cofactors, and macromolecular interactions," Chemical Reviews, vol. 101, no. 8, pp. 23532364, 2001.

[173] J. Roffey, C. Rosse, M. Linch, A. Hibbert, N. Q. McDonald, and P. J. Parker, "Protein kinase C intervention: the state of play," Current Opinion in Cell Biology, vol. 21, no. 2, pp. 268279, 2009.

[174] T. Eichholtz, D. B. A. de Bont, J. de Widt, R. M. J. Liskamp, and H. L. Ploegh, "A myristoylated pseudosubstrate peptide, a novel protein kinase C inhibitor," Journal of Biological Chemistry, vol. 268, no. 3, pp. 1982-1986, 1993.

[175] S. J. Persaud, "Protein kinase C signalling in pancreatic $\beta$ cells: cellular and molecular approaches," Digestion, vol. 58, no. 2, pp. 86-92, 1997.

[176] M. H. Disatnik, S. C. Boutet, C. H. Lee, D. Mochly-Rosen, and T. A. Rando, "Sequential activation of individual PKC isozymes in integrin-mediated muscle cell spreading: a role for MARCKS in an integrin signaling pathway," Journal of Cell Science, vol. 115, no. 10, pp. 2151-2163, 2002.

[177] A. Harishchandran and R. Nagaraj, "Interaction of a pseudosubstrate peptide of protein kinase $\mathrm{C}$ and its myristoylated form with lipid vesicles: only the myristoylated form translocates into the lipid bilayer," Biochimica et Biophysica Acta, vol. 1713, pp. 73-82, 2005.

[178] I. Spyridopoulos, C. Luedemann, D. Chen et al., "Divergence of angiogenic and vascular permeability signaling by VEGF: inhibition of protein kinase C suppresses VEGF-induced angiogenesis, but promotes VEGF-induced, NO-dependent vascular permeability," Arteriosclerosis, Thrombosis, and Vascular Biology, vol. 22, pp. 901-906, 2002.

[179] A. Shpakov, M. Pertseva, L. Kuznetsova, and S. Plesneva, "A novel, adenylate cyclase, signaling mechanism of relaxin $\mathrm{H} 2$ action," Annals of the New York Academy of Sciences, vol. 1041, pp. 305-307, 2005.

[180] F. M. Cunha, D. A. Berti, Z. S. Ferreira, C. F. Klitzke, R. P. Markus, and E. S. Ferro, "Intracellular peptides as natural regulators of cell signaling," Journal of Biological Chemistry, vol. 283, no. 36, pp. 24448-24459, 2008. 

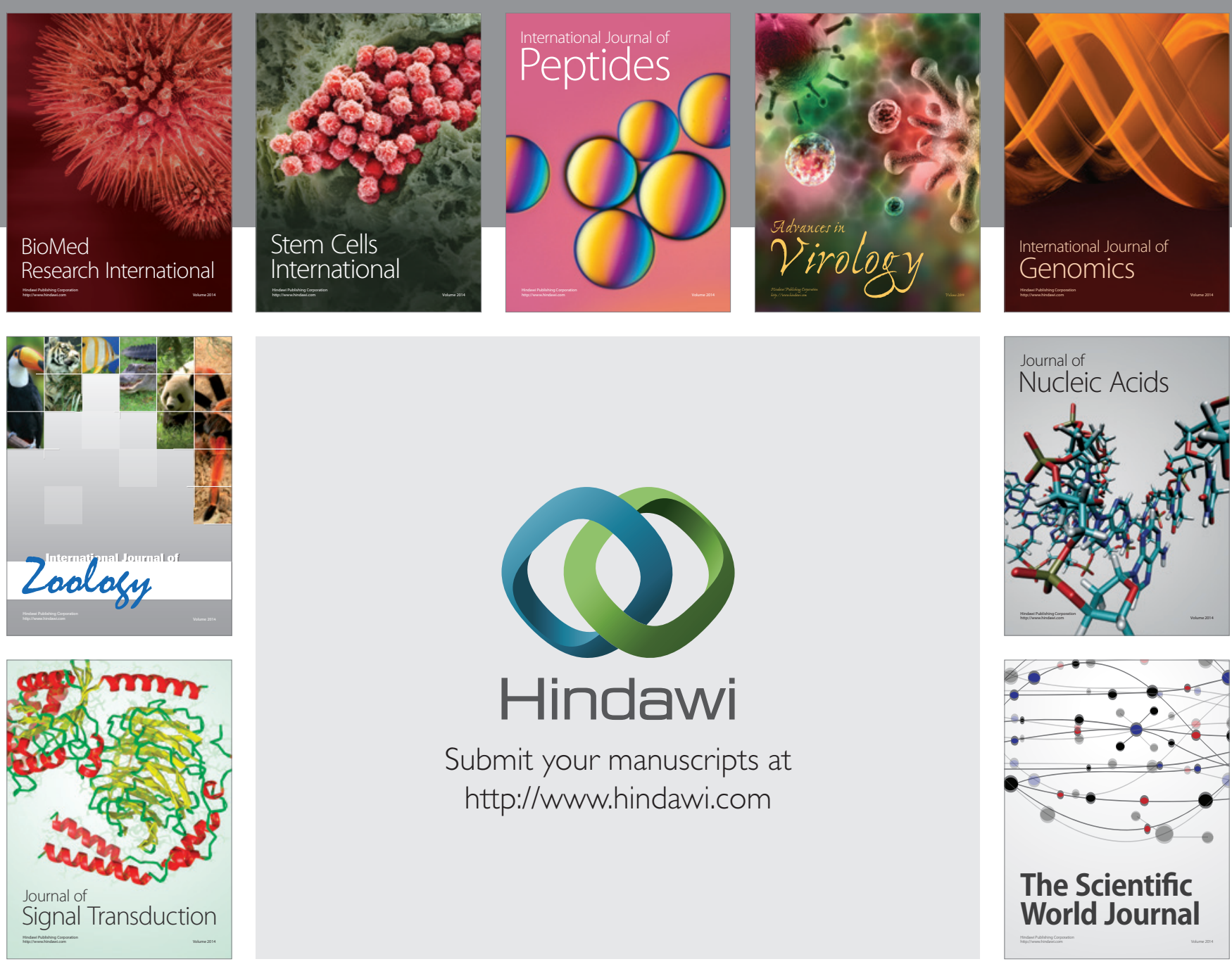

Submit your manuscripts at

http://www.hindawi.com
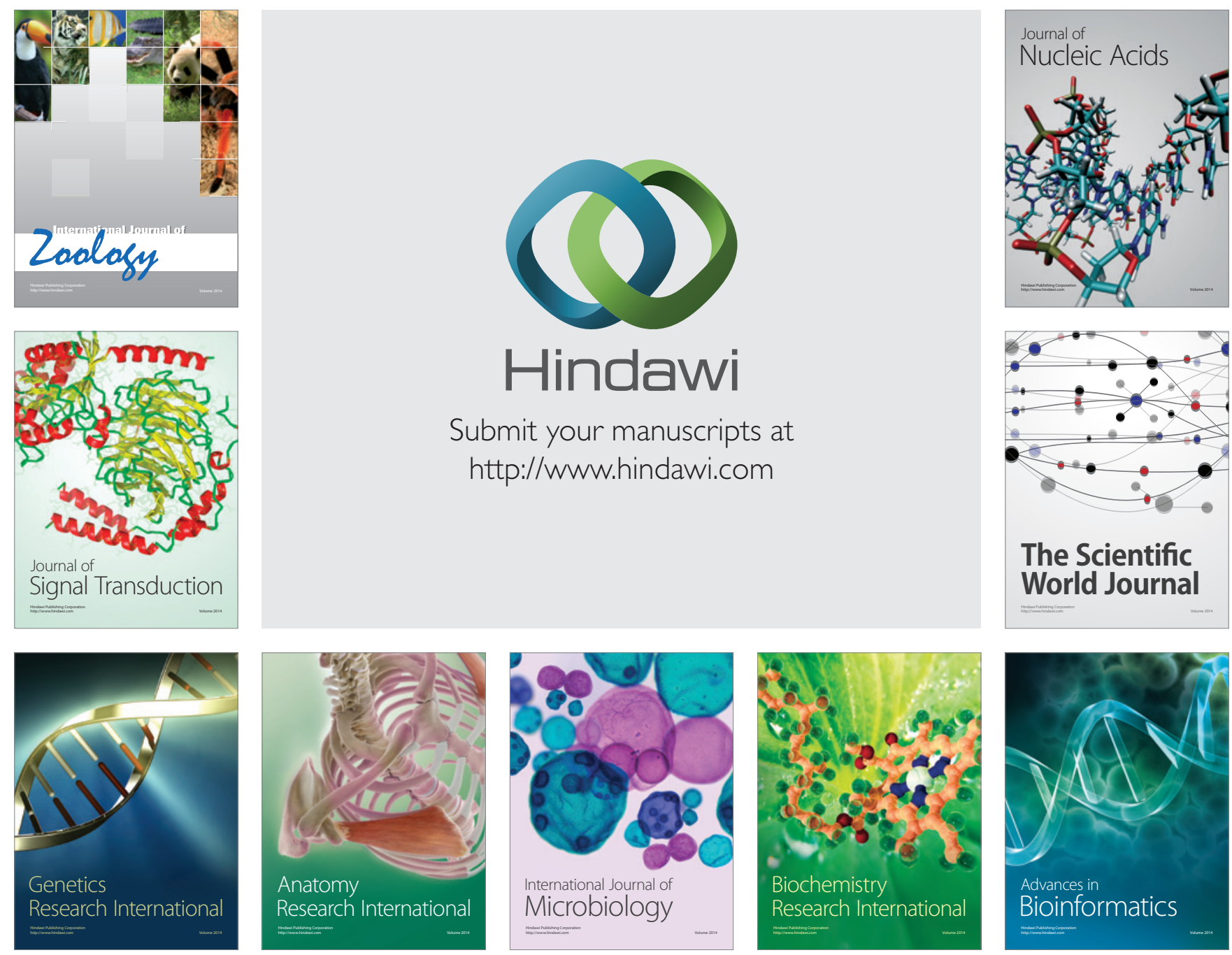

The Scientific World Journal
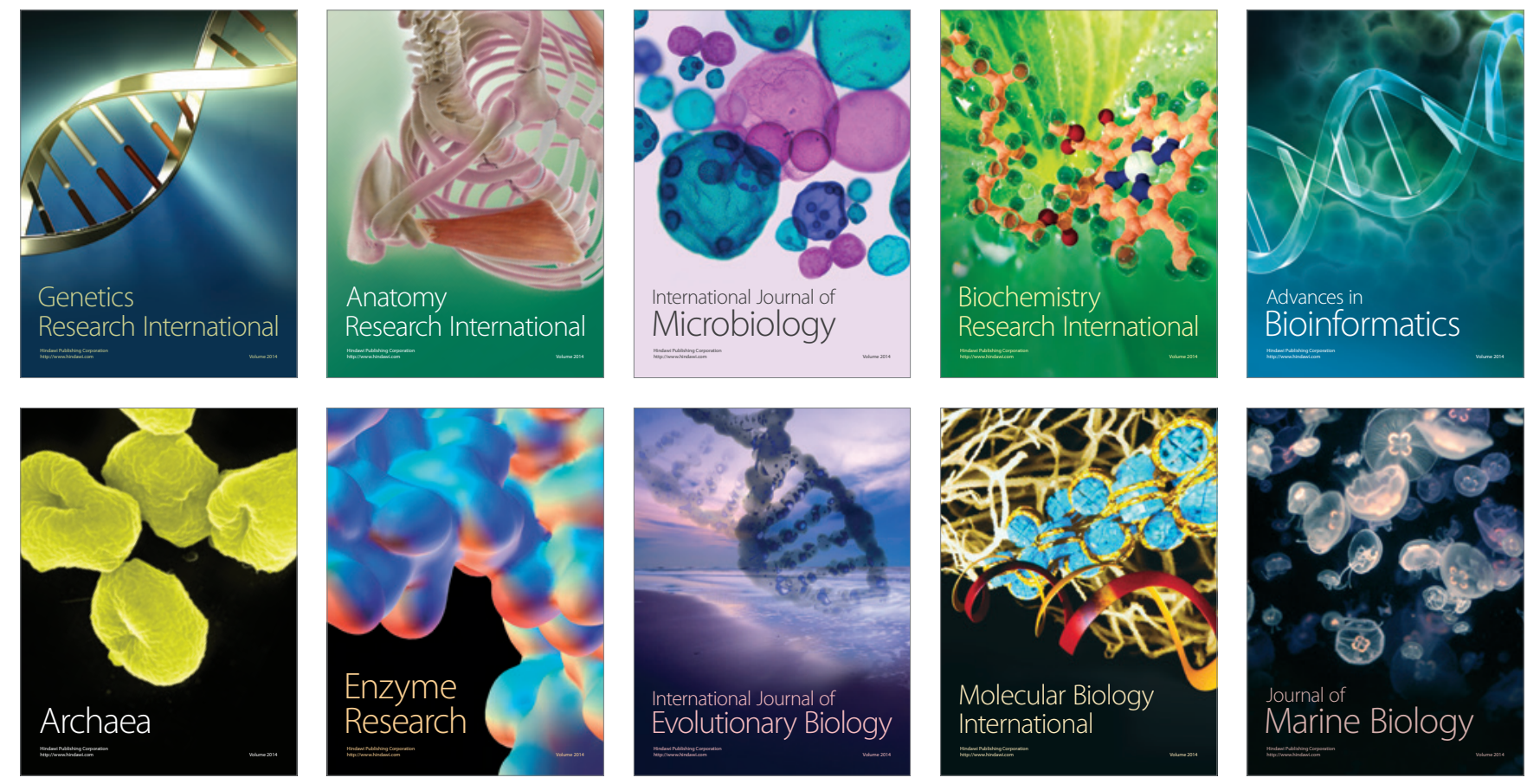